\title{
Total Synthesis of Guanacastepene A: A Route to Enantiomeric Control
}

\author{
Mihirbaran Mandal, ${ }^{1}$ Heedong Yun, ${ }^{2}$ Gregory B. Dudley, ${ }^{3}$ Songnian Lin, ${ }^{4}$ Derek S. \\ Tan, ${ }^{5}$ Samuel J. Danishefsky ${ }^{1,2, *}$ \\ ${ }^{1}$ Laboratory for Bioorganic Chemistry, Sloan-Kettering Institute for Cancer Research, 1275 York Avenue, \\ Box 106, New York, New York 10021 \\ ${ }^{2}$ Department of Chemistry, Columbia University, Havemeyer Hall, 3000 Broadway, New York, New York \\ 10027 \\ ${ }^{3}$ Department of Chemistry and Biochemistry, The Florida State University, Tallahassee, FL 32306 \\ ${ }^{4}$ Department of Medicinal Chemistry, Merck Research Laboratories, Rahway, NJ 07065 \\ ${ }^{5}$ Tri-Institutional Research Program and Molecular Pharmacology \& Chemistry Program, Memorial \\ Sloan-Kettering Cancer Center, 1275 York Avenue, Box 422, New York, NY 10021
}

\section{Table of contents}

General Experimental methods $\quad$ S4

Experimental of $\mathbf{9}$ S5

Experimental and spectral data of $\mathbf{1 1}$ S5

Experimental and spectral data of $\mathbf{1 2}$ S6

Experimental of $14 \quad$ S6

$\begin{array}{ll}\text { Experimental and spectral data of } \mathbf{1 6} & \text { S7 }\end{array}$

$\begin{array}{ll}\text { Experimental and spectral data of } \mathbf{1 7} & \text { S7 }\end{array}$

Experimental and spectral data of $\mathbf{2 0}$ S8

Experimental and spectral data of $\mathbf{1 7 - \mathbf { d } _ { 2 }} \quad$ S9

Experimental and spectral data of $\mathbf{2 7}$ S9

Experimental and spectral data of $\mathbf{2 8} \quad \mathrm{S} 10$

Experimental and spectral data of $\mathbf{2 9} \quad \mathrm{S} 11$

Experimental and spectral data of $\mathbf{3 2} \quad$ S11

Experimental and spectral data of $\mathbf{3 0} \quad \mathrm{S} 12$

Experimental and spectral data of $\mathbf{3 1} \quad \mathrm{S} 13$

$\begin{array}{ll}\text { Experimental and spectral data of } \mathbf{3 3} & \mathrm{S} 14\end{array}$ 
$\begin{array}{ll}\text { Experimental and spectral data of } 39 & \mathrm{~S} 14\end{array}$

Experimental and spectral data of $\mathbf{4 0} \quad \mathrm{S} 15$

Experimental and spectral data of $\mathbf{4 1} \quad \mathrm{S} 16$

$\begin{array}{ll}\text { Experimental and spectral data of } \mathbf{4 4} & \mathrm{S} 17\end{array}$

Experimental and spectral data of $\mathbf{4 5} \quad \mathrm{S} 18$

$\begin{array}{ll}\text { Experimental and spectral data of } \mathbf{4 6} & \mathrm{S} 17\end{array}$

Experimental and spectral data of $\mathbf{9 9} \quad \mathrm{S} 18$

Experimental and spectral data of $\mathbf{1 0 0} \quad \mathrm{S} 19$

Experimental and spectral data of $\mathbf{9 3} \quad \mathrm{S} 19$

Experimental and spectral data of $\mathbf{9 4} \quad$ S20

$\begin{array}{ll}\text { Experimental and spectral data of } \mathbf{9 8} & \text { S20 }\end{array}$

${ }^{1} \mathrm{H}$ and ${ }^{13} \mathrm{C}$ NMR spectra of $\mathbf{9}$

$\mathrm{S} 22-\mathrm{S} 23$

${ }^{1} \mathrm{H}$ and ${ }^{13} \mathrm{C}$ NMR spectra of $\mathbf{1 1}$

$\mathrm{S} 24-\mathrm{S} 25$

${ }^{1} \mathrm{H}$ and ${ }^{13} \mathrm{C}$ NMR spectra of $\mathbf{1 2}$

S26 - S27

${ }^{1} \mathrm{H}$ spectra of $\mathbf{1 6}$

S28

${ }^{1} \mathrm{H}$ and ${ }^{13} \mathrm{C}$ NMR spectra of $\mathbf{1 7}$

$\mathrm{S} 29$ - S30

${ }^{1} \mathrm{H}$ and ${ }^{13} \mathrm{C}$ NMR spectra of $\mathbf{1 7 - \mathbf { d } _ { 2 }}$

S31 - S32

${ }^{1} \mathrm{H}$ and ${ }^{13} \mathrm{C}$ NMR spectra of $\mathbf{1 8}$

S33 - S34

${ }^{1} \mathrm{H}$ and ${ }^{13} \mathrm{C}$ NMR spectra of 20

$\mathrm{S} 35$ - S36

${ }^{1} \mathrm{H}$ and ${ }^{13} \mathrm{C}$ NMR spectra of $\mathbf{2 7}$

S37 - S38

${ }^{1} \mathrm{H}$ and ${ }^{13} \mathrm{C}$ NMR spectra of $\mathbf{2 8}$

$\mathrm{S} 39$ - S40

${ }^{1} \mathrm{H}$ and ${ }^{13} \mathrm{C}$ NMR spectra of 29

$\mathrm{S} 41$ - S42

${ }^{1} \mathrm{H}$ and ${ }^{13} \mathrm{C}$ NMR spectra of $\mathbf{3 0}$

$\mathrm{S} 43-\mathrm{S} 44$

${ }^{1} \mathrm{H}$ and ${ }^{13} \mathrm{C}$ NMR spectra of $\mathbf{3 1}$

S45 - S46

${ }^{1} \mathrm{H}$ spectra of 32

S47

${ }^{1} \mathrm{H}$ and ${ }^{13} \mathrm{C}$ NMR spectra of 33

$\mathrm{S} 48-\mathrm{S} 49$

${ }^{1} \mathrm{H}$ and ${ }^{13} \mathrm{C}$ NMR spectra of 39

S50 - S51

${ }^{1} \mathrm{H}$ and ${ }^{13} \mathrm{C}$ NMR spectra of $\mathbf{4 1}$

S52 - S53

${ }^{1} \mathrm{H}$ spectra of $\mathbf{4 4}$

S54

${ }^{1} \mathrm{H}$ spectra of $\mathbf{4 5}$

S55 


$\begin{array}{ll}{ }^{1} \mathrm{H} \text { and }{ }^{13} \mathrm{C} \text { NMR spectra of } \mathbf{5 3} & \mathrm{S} 56-\mathrm{S} 57 \\ { }^{1} \mathrm{H} \text { and }{ }^{13} \mathrm{C} \text { NMR spectra of } \mathbf{5 4} & \mathrm{S} 58-\mathrm{S} 59 \\ { }^{1} \mathrm{H} \text { and }{ }^{13} \mathrm{C} \text { NMR spectra of } \mathbf{5 5} & \mathrm{S} 60-\mathrm{S} 61 \\ { }^{1} \mathrm{H} \text { and }{ }^{13} \mathrm{C} \text { NMR spectra of } \mathbf{5 6} & \mathrm{S} 62-\mathrm{S} 63 \\ { }^{1} \mathrm{H} \text { spectra of } \mathbf{5 7} & \mathrm{S} 64 \\ { }^{1} \mathrm{H} \text { spectra of } \mathbf{5 8} & \mathrm{S} 65 \\ { }^{1} \mathrm{H} \text { spectra of } \mathbf{5 9} & \mathrm{S} 66 \\ { }^{1} \mathrm{H} \text { spectra of } \mathbf{6 0} & \mathrm{S} 67 \\ { }^{1} \mathrm{H} \text { and }{ }^{13} \mathrm{C} \text { NMR spectra of } \mathbf{6 1} & \mathrm{S} 68-\mathrm{S} 69 \\ { }^{1} \mathrm{H} \text { and }{ }^{13} \mathrm{C} \text { NMR spectra of } \mathbf{6 2} & \mathrm{S} 70-\mathrm{S} 71 \\ { }^{1} \mathrm{H} \text { and }{ }^{13} \mathrm{C} \text { NMR spectra of } \mathbf{6 3} & \mathrm{S} 72-\mathrm{S} 73 \\ { }^{1} \mathrm{H} \text { and }{ }^{13} \mathrm{C} \text { NMR spectra of } \mathbf{6 4} & \mathrm{S} 74-\mathrm{S} 75 \\ { }^{1} \mathrm{H} \text { spectra of } \mathbf{6 9} & \mathrm{S} 76 \\ { }^{1} \mathrm{H} \text { spectra of } \mathbf{7 0} & \mathrm{S} 77 \\ { }^{1} \mathrm{H} \text { and }{ }^{13} \mathrm{C} \text { NMR spectra of } \mathbf{7 3} & \mathrm{S} 78-\mathrm{S} 79 \\ { }^{1} \mathrm{H} \text { and }{ }^{13} \mathrm{C} \text { NMR spectra of } \mathbf{7 4} & \mathrm{S} 80-\mathrm{S} 81 \\ { }^{1} \mathrm{H} \text { and }{ }^{13} \mathrm{C} \text { NMR spectra of } \mathbf{1} & \mathrm{S} 82-\mathrm{S} 83 \\ { }^{1} \mathrm{H} \text { and }{ }^{13} \mathrm{C} \text { NMR spectra of } \mathbf{1 0 0} & \mathrm{S} 84 \\ { }^{1} \mathrm{H} \text { and }{ }^{13} \mathrm{C} \text { NMR spectra of } \mathbf{9 3} & \mathrm{S} 85 \\ { }^{1} \mathrm{H} \text { and }{ }^{13} \mathrm{C} \text { NMR spectra of } \mathbf{9 4} & \mathrm{S} 86 \\ { }^{1} \mathrm{H} \text { and }{ }^{13} \mathrm{C} \text { NMR spectra of } \mathbf{9 8} & \mathrm{S} 87 \\ \mathrm{X}_{\mathrm{X}} \text { Ray Structure of } \mathbf{7 3} & \mathrm{S} 88-\mathrm{S} 89\end{array}$




\section{General Experimental Procedures}

Commercial reagents were used without further purification unless otherwise indicated. Solvents were degassed with Ar and purified on a solvent drying system as described in Pangborn, A. B.; Giardello, M. A.; Grubbs, R. H.; Rosen,

R. K.; Timmers, F. J. Organometallics 1996, 15, 1518-1520 unless otherwise indicated. Triethylamine $\left(\mathrm{Et}_{3} \mathrm{~N}\right)$, pyridine (py), and trimethylsilylchloride (TMSCl) were distilled from $\mathrm{CaH}_{2}$ under $\mathrm{N}_{2}$. Hexamethylphosphoramide (HMPA, $\left.\left(\mathrm{Me}_{2} \mathrm{~N}\right)_{3} \mathrm{P}=\mathrm{O}\right)$ was distilled from $\mathrm{CaH}_{2}$ and stored over $4 \AA$ MS. Reactions were performed in flame- or oven-dried glassware under positive Ar pressure with stirring by a magnetic stirbar unless otherwise indicated. Cold baths were generated as follows: $0{ }^{\circ} \mathrm{C}$, wet ice/water; $-44^{\circ} \mathrm{C}$, dry ice/ $\mathrm{CH}_{3} \mathrm{CN} ;-78{ }^{\circ} \mathrm{C}$, dry ice/acetone. Flash chromatography was performed on E. Merck 60 230-400 mesh silica gel. TLC was performed on $0.25 \mathrm{~mm}$ E. Merck silica gel $60 \mathrm{~F} 254$ plates and visualized by UV (254 nm) and cerium ammonium molybdenate. IR spectra were recorded on an FTIR spectrometer with peaks reported in $\mathrm{cm}^{-1}$. NMR spectra were recorded at $24{ }^{\circ} \mathrm{C}$ unless otherwise indicated. Chemical shifts are expressed in ppm

relative to TMS $\left({ }^{1} \mathrm{H}, 0.00 \mathrm{ppm}\right)$ or residual $\mathrm{CDCl}_{3}\left({ }^{13} \mathrm{C}, 77.0 \mathrm{ppm}\right)$. Peak assignments were made on the basis of J-RES, COSY, NOESY, DEPT, HMQC, and HMBC experiments. ${ }^{1} \mathrm{H}$ notations: $\mathrm{m}=$ multiplet, obsc $=$ obscured, app $=$ apparent. ${ }^{13} \mathrm{C}$ DEPT notations: $\mathrm{q}=$ quaternary $\mathrm{C}$, e $=\mathrm{CH}_{2}, \mathrm{o}=\mathrm{CH}$ or $\mathrm{CH}_{3} . \mathrm{H}_{\mathrm{a}}$ and $\mathrm{H}_{\mathrm{b}}$ indicate stereochemistry not determined. $\mathrm{H}_{\alpha}$ and $\mathrm{H}_{\beta}$ indicate stereochemistry as drawn. Atom numbering in structures is based on the numbering system for guanacastepene A with additional groups assigned arbitrary numbers above 22 . Low resolution mass spectra were obtained by electrospray (ESI) ionization. High resolution mass spectra were obtained by fast atom bombardment (FAB) ionization. 


\section{Experimental and spectral data of compounds:}
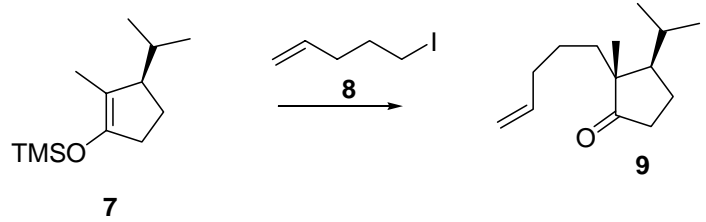

Keto-olefin 9. A 50-mL, one-necked, round-bottomed flask equipped with a rubber septum pierced with an argon inlet needle was charged with a solution of 7 (0.429 g, $2.0 \mathrm{mmol})$ in $15 \mathrm{~mL}$ of THF and cooled at $0{ }^{\circ} \mathrm{C}$ while a solution of methyllithium-lithium iodide $(1.0 \mathrm{M}$ in ether, $2.1 \mathrm{~mL}, 2.1 \mathrm{mmol}$ ) was added rapidly dropwise by syringe. The resulting solution was stirred for $1 \mathrm{~h}$, then cooled at $-78^{\circ} \mathrm{C}$ while a solution of 5-iodo-1-pentene (8) $(0.98 \mathrm{~g}, 5.0 \mathrm{mmol})$ in $5 \mathrm{~mL}$ of hexamethylphosphoramide (HMPA) was added rapidly by syringe. The resulting slurry was allowed to stir overnight $(17 \mathrm{~h})$ with gradual warming to room temperature to give a yellow solution, which was diluted with $45 \mathrm{~mL}$ of ether and washed with three $10-\mathrm{mL}$ portions of water and $10 \mathrm{~mL}$ of saturated $\mathrm{NaCl}$ solution. The organic layer was then dried over $\mathrm{MgSO}_{4}$, filtered, and concentrated to give $0.93 \mathrm{~g}$ of a faintly yellow liquid. Purification by column chromatography on $42 \mathrm{~g}$ of silica gel (elution with $5 \%$ ether in pentane) provided $0.267 \mathrm{~g} \mathrm{(63 \% )}$ of $\mathbf{9}$ as a colorless oil. Spectral data for $\mathbf{9}$ was consistent with that reported previously for this compound.
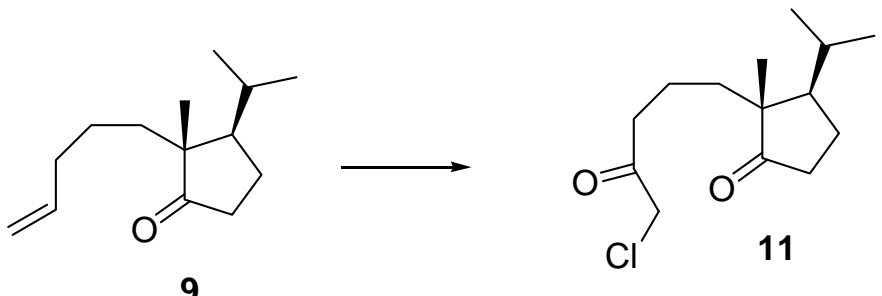

a-Chloro ketone 11. A 15-mL, one-necked, pear-shaped flask was charged with a mixture of 9 (0.104 g, $0.50 \mathrm{mmol})$, water $(0.5 \mathrm{~mL})$, chloramine-T $(0.282 \mathrm{~g}, 1.0 \mathrm{mmol})$, and 0.5 $\mathrm{mL}$ of acetone. Sulfuric acid ( $3.0 \mathrm{M}$ in water, $0.25 \mathrm{~mL}, 0.75 \mathrm{mmol}$ ) was added dropwise, and the resulting mixture was heated at $50^{\circ} \mathrm{C}$ for $30 \mathrm{~min}$, then cooled to room temperature and diluted with $2.5 \mathrm{~mL}$ of acetone. A mixture of $\mathrm{CrO}_{3}(0.50 \mathrm{~g}, 5.0 \mathrm{mmol})$ and $\mathrm{H}_{2} \mathrm{SO}_{4}(3.0 \mathrm{M}$ in water, 2.5 $\mathrm{mL}, 7.5 \mathrm{mmol}$ ) (Jones reagent) was then added, and the resulting orange-brown mixture was stirred for $30 \mathrm{~min}$ at room temperature before isopropanol $(1.0 \mathrm{~mL}, 13 \mathrm{mmol})$ was added. After an additional $30 \mathrm{~min}$, the reaction mixture was diluted with $20 \mathrm{~mL}$ of water and extracted with three 10 -mL portions of ethyl acetate. The combined organic layers were washed with $10 \mathrm{~mL}$ of saturated $\mathrm{NaCl}$ solution, dried over $\mathrm{MgSO}_{4}$, filtered, and deposited onto $0.39 \mathrm{~g}$ of silica gel. Purification by column chromatography on $13 \mathrm{~g}$ of silica gel (elution with $10 \%$ ethyl acetate in hexanes) provided $82 \mathrm{mg}$ (63\%) of $\mathbf{1 1}$ as a colorless oil: IR (thin film) 2962, 1734, 1458, 1405, 1170, 1087, and $956 \mathrm{~cm}^{-1} ;{ }^{1} \mathbf{H}$ NMR $\left(400 \mathrm{MHz}, \mathrm{CDCl}_{3}\right) \delta 4.06(\mathrm{~s}, 2 \mathrm{H}), 2.53-2.61(\mathrm{~m}, 2 \mathrm{H}), 2.33-$ $2.40(\mathrm{~m}, 1 \mathrm{H}), 2.00-2.14(\mathrm{~m}, 2 \mathrm{H}), 1.64-1.81(\mathrm{~m}, 4 \mathrm{H}), 1.43-1.57(\mathrm{~m}, 2 \mathrm{H}), 1.14-1.22(\mathrm{~m}, 1 \mathrm{H})$, 1.02 (d, $J=6.6 \mathrm{~Hz}, 3 \mathrm{H}), 0.96$ (d, $J=6.6 \mathrm{~Hz}, 3 \mathrm{H})$, and 0.89 (s, 3H); ${ }^{13} \mathrm{C}$ NMR (100 MHz, $\left.\mathrm{CDCl}_{3}\right) \delta 224.1,202.3$, 52.0, 48.1, 48.0, 40.0, 37.5, 36.5, 29.4, 23.7, 22.0, 21.4, 18.9, and 18.2. HRMS Calcd for $\mathrm{C}_{14} \mathrm{H}_{23} \mathrm{ClO}_{2}$ : 258.1387. Found: $259.1466\left(\mathrm{M}+\mathrm{H}^{+}\right)$. 

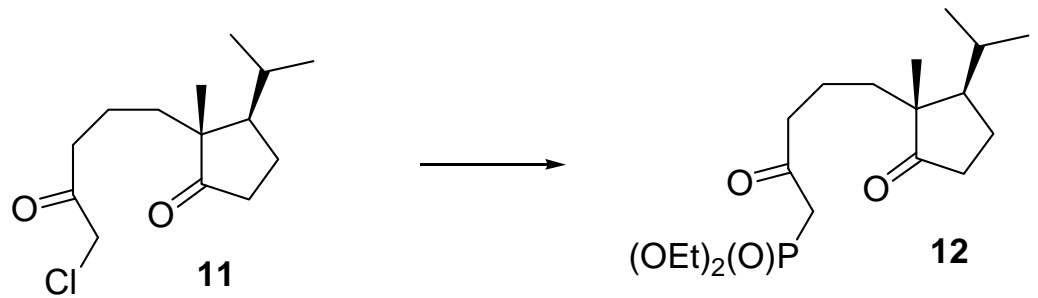

$\beta$-Ketophosphonate 12. A 15-mL, one-necked, pear-shaped flask equipped with an argon inlet was charged with a solution of 11 ( $55 \mathrm{mg}, 0.21 \mathrm{mmol}$ ) in $2 \mathrm{~mL}$ of acetone, and $\mathrm{NaI}$ (95 mg, 0.63 $\mathrm{mmol}$ ) was added. The resulting mixture was stirred in the dark for $15 \mathrm{~min}$, then was partitioned between $10 \mathrm{~mL}$ of ether and $2 \mathrm{~mL}$ of water. The organic layer was washed with 2-mL portions of $1 \mathrm{M} \mathrm{Na}_{2} \mathrm{~S}_{2} \mathrm{O}_{3}$ solution, water, and saturated $\mathrm{NaCl}$ solution, dried over $\mathrm{MgSO}_{4}$, filtered, and concentrated (protected from light) to give $75 \mathrm{mg}$ colorless oil, which was immediately dissolved in $5 \mathrm{~mL}$ of benzene in 25-mL, one-necked, pear-shaped flask equipped with a reflux condenser with an argon inlet. Triethyl phosphite $(55 \mu \mathrm{L}, 0.32 \mathrm{mmol})$ was added, and the resulting solution was heated at reflux for $5 \mathrm{~h}$ in the dark and then cooled to room temperature and concentrated to give $89 \mathrm{mg}$ of a colorless oil. Purification by column chromatography on $8 \mathrm{~g}$ of silica gel (gradient elution with 50-100\% ethyl acetate in hexanes) provided $56 \mathrm{mg}(74 \%)$ of $\mathbf{1 2}$ as a colorless oil: IR (thin film) 3476, 2963, 1732, 1460, 1406, 1369, 1256, 1164, 1025, 967, and 800 $\mathrm{cm}^{-1}$; ${ }^{1} \mathbf{H}$ NMR (400 MHz, $\mathrm{CDCl}_{3}$ ) $\delta 4.14$ (apparent quint, $\left.J=7.0 \mathrm{~Hz}, 4 \mathrm{H}\right), 3.05\left(\mathrm{~d}, J_{\mathrm{H}-\mathrm{P}}=22.7\right.$ $\mathrm{Hz}, 2 \mathrm{H}), 2.51-2.63$ (m, 2H), 2.31-2.40 (m, 1H), 2.00-2.12 (m, 2H), 1.78-1.84 (m, 1H), 1.621.72 (m, 3H), 1.42-1.50 (m, 2H), 1.34 (t, $J=7.0 \mathrm{~Hz}, 6 \mathrm{H}), 1.13-1.20$ (m, 1H), 1.01 (d, $J=6.6$ $\mathrm{Hz}, 3 \mathrm{H}), 0.95$ (d, $J=6.3 \mathrm{~Hz}, 3 \mathrm{H}$ ), and $0.88(\mathrm{~s}, 3 \mathrm{H}) ;{ }^{13} \mathbf{C}$ NMR $\delta 224.2,201.7$ (d, $J_{\mathrm{C}-\mathrm{P}}=6.1 \mathrm{~Hz}$ ), 62.5 (m), 52.0, 48.0, 44.3, 42.3 (d, $J_{\mathrm{C}-\mathrm{P}}=127.3 \mathrm{~Hz}$ ), 37.6, 36.6, 29.4, 23.7, 22.0, 21.5, 18.8, 18.2, and $16.3\left(\mathrm{~d}, J_{\mathrm{C}-\mathrm{P}}=6.1 \mathrm{~Hz}\right)$; ESIMS $\mathrm{m} / \mathrm{z} 361.4\left(\mathrm{M}+\mathrm{H}^{+}, \mathrm{C}_{18} \mathrm{H}_{33} \mathrm{O}_{5} \mathrm{P}\right.$ requires 361.4).
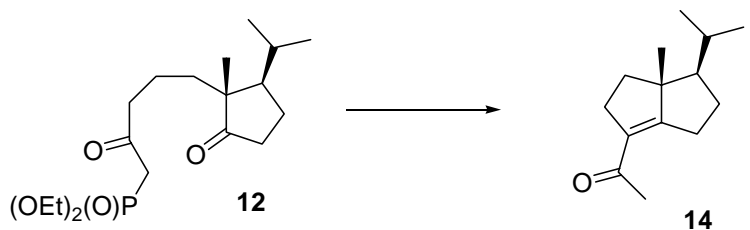

[5,5]-Bicyclic enone 14. A 50-mL, one-necked, round-bottomed flask equipped with a reflux condenser with an argon inlet was charged with 12 (42 mg, 0.11 mmol), $\mathrm{Cs}_{2} \mathrm{CO}_{3}(0.19 \mathrm{~g}, 0.58$ $\mathrm{mmol}$ ), and $22 \mathrm{~mL}$ of toluene, and the resulting mixture was heated at reflux for $12 \mathrm{~h}$, then cooled to room temperature. The liquid was decanted, washed with $5 \mathrm{~mL}$ of water and $5 \mathrm{~mL}$ of saturated $\mathrm{NaCl}$ solution, dried with $\mathrm{MgSO}_{4}$, filtered, and concentrated. Purification by column chromatography on $5 \mathrm{~g}$ of silica gel (elution with $10 \%$ ethyl acetate in hexanes) provided $21 \mathrm{mg}$ (83\%) of $\mathbf{1 4}$ as a colorless oil. Spectral data for $\mathbf{1 4}$ was consistent with that reported previously for this compound. 


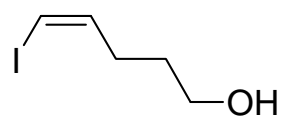

15

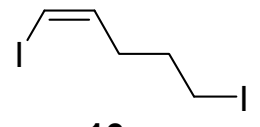

16

Diiodide 16. A 500-mL, one-necked, round-bottomed flask equipped with an argon inlet was charged with a mixture of triphenylphosphine (14.69 g, $56 \mathrm{mmol}$ ), imidazole (3.81 g, $56 \mathrm{mmol}$ ), and $150 \mathrm{~mL}$ of $\mathrm{CH}_{2} \mathrm{Cl}_{2}$ and immersed in a room temperature water bath. The stirred mixture became homogeneous within $5 \mathrm{~min}$, at which time iodine $(14.21 \mathrm{~g}, 56 \mathrm{mmol})$ was added. After an additional $10 \mathrm{~min}$, a solution of $\mathbf{1 5}(7.9 \mathrm{~g}, 37 \mathrm{mmol})$ in $35 \mathrm{~mL}$ of $\mathrm{CH}_{2} \mathrm{Cl}_{2}$ was added. The resulting mixture was stirred for $1 \mathrm{~h}$ in the dark, then diluted with $185 \mathrm{~mL}$ of hexanes, filtered through Celite with the aid of three 50-mL portions of hexanes, and concentrated. Purification by column chromatography on $60 \mathrm{~g}$ of silica gel (elution with hexanes) provided $11.0 \mathrm{~g}(92 \%)$ of 16 as a colorless liquid: IR (thin film) 3062, 2934, 2835, 1608, 1425, 1305, 1280, 1263, 1198, 1164, and $691 \mathrm{~cm}^{-1} ;{ }^{1} \mathbf{H}$ NMR (400 MHz, $\left.\mathrm{CDCl}_{3}\right) \delta 6.30(\mathrm{~d}, J=7.4 \mathrm{~Hz}, 1 \mathrm{H}), 6.18$ (apparent q, $J$ $=7.1 \mathrm{~Hz}, 1 \mathrm{H}$ ), $3.21(\mathrm{t}, J=7.0 \mathrm{~Hz}, 2 \mathrm{H}$ ), 2.27 (apparent q, $J=7.2 \mathrm{~Hz}, 2 \mathrm{H}$ ), and 1.98 (apparent quint, $J=7.2 \mathrm{~Hz}, 2 \mathrm{H}) ;{ }^{13} \mathrm{C}$ NMR $\left(100 \mathrm{MHz}, \mathrm{CDCl}_{3}\right) \delta 139.0,84.0,35.6,31.8$, and 5.4.

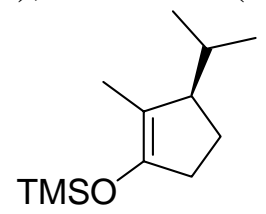

7

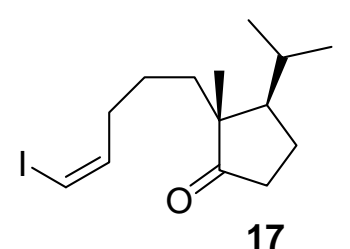

17

Vinyl iodide 17. A 200-mL, one-necked, round-bottomed flask equipped with a rubber septum pierced with an argon inlet needle was charged with a solution of $7(1.91 \mathrm{~g}, 9.0 \mathrm{mmol})$ in $66 \mathrm{~mL}$ of THF and cooled at $0{ }^{\circ} \mathrm{C}$ while a solution of methyllithium-lithium iodide $(0.93 \mathrm{M}$ in ether, 9.8 $\mathrm{mL}, 9.1 \mathrm{mmol}$ ) was added rapidly dropwise by syringe. The resulting solution was stirred for 1 $\mathrm{h}$, then cooled at $-78{ }^{\circ} \mathrm{C}$ while a solution of $16(7.22 \mathrm{~g}, 22 \mathrm{mmol})$ in $22 \mathrm{~mL}$ of hexamethylphosphoramide (HMPA) was added rapidly by syringe. The resulting slurry was allowed to stir overnight $(14 \mathrm{~h})$ with gradual warming to room temperature to give a yellow solution, which was diluted with $200 \mathrm{~mL}$ of ether and washed with three $40-\mathrm{mL}$ portions of water and $40 \mathrm{~mL}$ of saturated $\mathrm{NaCl}$ solution. The organic layer was then dried over $\mathrm{MgSO}_{4}$, filtered, and concentrated to give a yellow oil. Purification by column chromatography on $75 \mathrm{~g}$ of silica gel (gradient elution with 2-5\% ethyl acetate in hexanes) provided ca. $4.5 \mathrm{~g}$ of unreacted 16, followed by $2.28 \mathrm{~g}$ (76\%) of $\mathbf{1 7}$ as a colorless oil: IR (thin film) 2959, 2870, 1736, 1608, 1458, 1406, 1386, 1373, 1281, 1231, and $1080 \mathrm{~cm}^{-1} ;{ }^{1} \mathbf{H}$ NMR (400 MHz, $\left.\mathrm{CDCl}_{3}\right) \delta 6.20$ (d, $J=$ $7.4 \mathrm{~Hz}, 1 \mathrm{H}), 6.14$ (apparent q, $J=6.8 \mathrm{~Hz}, 1 \mathrm{H}), 2.32-2.40(\mathrm{~m}, 1 \mathrm{H}), 2.01-2.13(\mathrm{~m}, 4 \mathrm{H}), 1.65-1.82$ (m, 3H), 1.42-1.58 (m, 3H), 1.00-1.15 (m, 1H), 1.01 (d, $J=6.4 \mathrm{~Hz}, 3 \mathrm{H}), 0.95$ (d, $J=6.4 \mathrm{~Hz}$, $3 \mathrm{H})$, and $0.90(\mathrm{~s}, 3 \mathrm{H}) ;{ }^{13} \mathrm{C}$ NMR $\left(100 \mathrm{MHz}, \mathrm{CDCl}_{3}\right) \delta 224.1,140.8,82.7,52.0,48.2,37.6,36.9$, 35.0, 29.4, 23.7, 23.3, 22.1, 21.5, and 18.3. HRMS Calcd for $\mathrm{C}_{14} \mathrm{H}_{23} \mathrm{IO}$ : 334.0794. Found: $335.0875\left(\mathrm{M}+\mathrm{H}^{+}\right)$. 


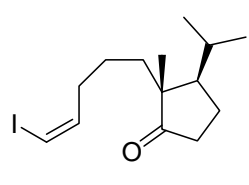

17

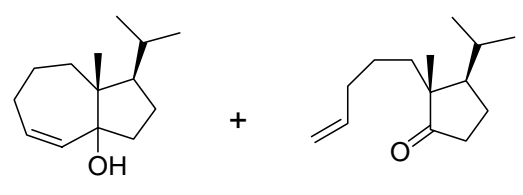

18

19

Allylic alcohol 18. A 500-mL, three-necked, round-bottomed flask equipped with an argon inlet, a 250-mL pressure equalizing dropping funnel, and a rubber septum was charged with 150 $\mathrm{mL}$ of THF and cooled in a $0^{\circ} \mathrm{C}$ bath. A solution of $n$-butyllithium $(2.5 \mathrm{M}$ in hexanes, $9.0 \mathrm{~mL}$, $22.5 \mathrm{mmol}$ ) was added, followed immediately by dropwise addition of a solution of $\mathbf{1 7}$ (1.50 g, $4.5 \mathrm{mmol}$ ) in $150 \mathrm{~mL}$ of THF over $40 \mathrm{~min}$. The resulting solution was stirred for $30 \mathrm{~min}$, then was diluted with $50 \mathrm{~mL}$ of water and washed with two $50-\mathrm{mL}$ portions of saturated $\mathrm{NaCl}$ solution. The combined aqueous solutions were extracted with $50 \mathrm{~mL}$ of ether, and the combined organic phases were dried over $\mathrm{MgSO}_{4}$, filtered, and concentrated to give a wet orange oil. Purification by column chromatography on $93 \mathrm{~g}$ of silica gel (gradient elution with $2.5-10 \%$ ethyl acetate in hexanes) provided $0.15 \mathrm{~g}$ (16\%) of 19, followed by $0.580 \mathrm{~g}(62 \%)$ of 18 as a yellow oil: IR (thin film) 3616, 3468, 2956, 2879, 1458, 1376, 1013, and $704 \mathrm{~cm}^{-1}$; ${ }^{1} \mathbf{H}$ NMR (400 MHz, $\left.\mathrm{CDCl}_{3}\right) \delta$ 5.59-5.69 (m, 2H), 2.23-2.42 (m, 1H), 2.03-2.18 (m, 2H), 1.65-1.82 (m, 4H), $1.32-1.62(\mathrm{~m}, 6 \mathrm{H}), 0.99(\mathrm{~s}, 3 \mathrm{H}), 0.93(\mathrm{~d}, J=6.5 \mathrm{~Hz}, 3 \mathrm{H})$, and $0.86(\mathrm{~d}, J=6.5 \mathrm{~Hz}, 3 \mathrm{H}) ;{ }^{13} \mathrm{C}$ NMR $\left(100 \mathrm{MHz}, \mathrm{CDCl}_{3}\right) \delta 137.6,132.0,83.3,53.9,49.1,40.1,39.7,30.4,30.2,24.8,23.0$, 22.3, 19.4, and 17.5. HRMS Calcd for $\mathrm{C}_{14} \mathrm{H}_{24} 0$ : 208.1827. Found: 208.1818.

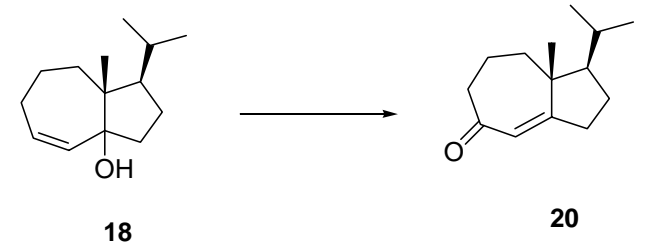

Hydroazulene 2. A 100-mL, one-necked, round-bottomed flask equipped with an argon inlet was charged with $4.84 \mathrm{~g}$ of oven-dried, powdered $3 \AA$ molecular sieves, PCC (2.42 g, 11.2 $\mathrm{mmol}$ ), and $19 \mathrm{~mL}$ of $\mathrm{CH}_{2} \mathrm{Cl}_{2}$. To this vigorously stirred suspension was added a solution of $\mathbf{1 8}$ $(0.78 \mathrm{~g}, 3.7 \mathrm{mmol})$ in $18 \mathrm{~mL}$ of $\mathrm{CH}_{2} \mathrm{Cl}_{2}$, and the resulting brown mixture was stirred for $30 \mathrm{~min}$ at room temperature and then deposited onto $9.7 \mathrm{~g}$ of silica gel. Purification on $77 \mathrm{~g}$ of silica gel (elution with $10 \%$ ethyl acetate in hexanes) provided $0.550 \mathrm{~g}$ (71\%) of $\mathbf{2 0}$ as a colorless oil: IR (thin film) 2956, 2870, 1652, 1464, 1426, 1366, 1336, 1260, 1191, 970, and $865 \mathrm{~cm}^{-1}$; ${ }^{1} \mathbf{H}$ NMR $\left(400 \mathrm{MHz}, \mathrm{CDCl}_{3}\right) \delta 5.81$ (apparent t, $J=1.7 \mathrm{~Hz}, 1 \mathrm{H}$ ), 2.37-2.71 (m, 4H), 2.12 (ddd, $J=13.9$, 7.2, and $3.5 \mathrm{~Hz}, 1 \mathrm{H}), 1.91-2.03(\mathrm{~m}, 1 \mathrm{H}), 1.78-1.90(\mathrm{~m}, 2 \mathrm{H}), 1.61-1.75(\mathrm{~m}, 2 \mathrm{H}), 1.43-1.57(\mathrm{~m}$, 2H), $1.05(\mathrm{~s}, 3 \mathrm{H}), 1.00(\mathrm{~d}, J=6.7 \mathrm{~Hz}, 3 \mathrm{H})$, and $0.93(\mathrm{~d}, J=6.7 \mathrm{~Hz}, 3 \mathrm{H}) ;{ }^{13} \mathbf{C}$ NMR $(100 \mathrm{MHz}$, $\left.\mathrm{CDCl}_{3}\right) \delta 204.3,171.9,123.8,58.6,50.0,44.2,38.8,32.9,27.9,25.6,24.1,22.0,21.0$, and 20.7. HRMS Calcd for $\mathrm{C}_{14} \mathrm{H}_{22} \mathrm{O}$ : 206.1671. Found: 206.1666. 


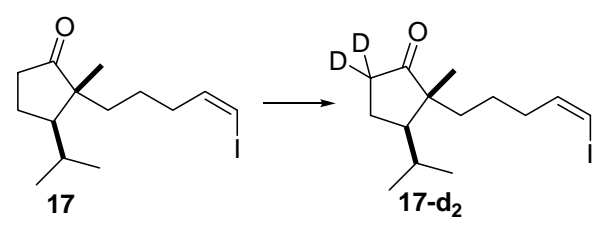

Dideuterated vinyl iodide 17-d $\mathbf{d}_{2}$ : Into a $25 \mathrm{~mL}$ round-bottomed flask, equipped with magnetic spin bar and argon filled balloon was taken 17 (182 mg, $0.54 \mathrm{mmol}$, azeotropically dried from toluene) in $4 \mathrm{~mL} \mathrm{CD} \mathrm{CD}_{3} \mathrm{OD}$. Freshly distilled triethyl amine $(0.22 \mathrm{~mL}, 1.62 \mathrm{mmol}, 3$ equiv.) was added and the resulting solution was stirred for $16 \mathrm{hr}$ at room temperature. Evaporation of the reaction mixture provided crude product, which was purified by silica gel column chromatography (3\% ethyl acetate in hexanes) to afford mono deuterated compound in $94 \%$ yield. This mono deuterated compound was further dissolved in $4 \mathrm{~mL} \mathrm{CD}_{3} \mathrm{OD}$ and $100 \mu \mathrm{L}$ of DBU was added. The resulting solution was stirred for $4 \mathrm{hr}$ at room temperature to obtain the

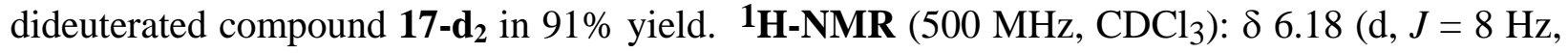
1H), 6.13 (apparent q, $J=6.5 \mathrm{~Hz}, 1 \mathrm{H}), 2.06(\mathrm{~m}, 3 \mathrm{H}), 1.79-1.64(\mathrm{~m}, 3 \mathrm{H}), 1.52-1.40(\mathrm{~m}, 3 \mathrm{H}), 1.07$ (m, 1H), 1.00 (d, $J=6.5 \mathrm{~Hz}, 3 \mathrm{H}), 0.93$ (d, $J=6.0 \mathrm{~Hz}, 3 \mathrm{H}), 0.88$ (s, 3H); ${ }^{13} \mathrm{C}-\mathbf{N M R}(125 \mathrm{MHz}$, $\left.\mathrm{CDCl}_{3}\right): \delta$ 224.6, 141.2, 83.1, 52.4, 48.7, 37.3, 35.4, 29.8, 23.9, 23.8, 22.6, 21.9, 18.7.

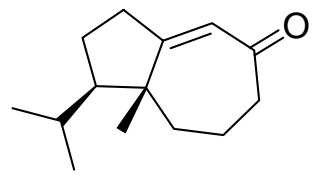

20

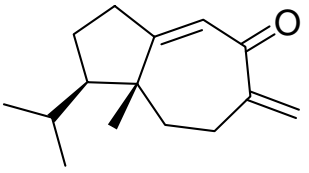

27

12 $\beta$-Isopropyl-11 $\beta$-methyl-8-exo-methylene-( $\left.\Delta^{1,2}\right)$-hydroazulen-3-one 27 . A solution of lithium hexamethyldisilazide (1.0 M in THF, $7.5 \mathrm{~mL}, 7.5 \mathrm{mmol}, 1.5$ equiv) and $12.5 \mathrm{~mL}$ of THF was cooled at $-78{ }^{\circ} \mathrm{C}$ in a 50 -mL pear-shaped flask under argon. A solution of hydroazulene 20 (1.03 g, $5.0 \mathrm{mmol}, 1.0$ equiv) in $15 \mathrm{~mL}$ of THF was added dropwise over $5 \mathrm{~min}$. The resulting solution was stirred for $1 \mathrm{~h}$ at $-78{ }^{\circ} \mathrm{C}$, then transferred via cannula over $15 \mathrm{~min}$ to a stirred suspension of Eschenmoser's salt (2.28 g, $12.3 \mathrm{mmol}, 2.5$ equiv) in $15 \mathrm{~mL}$ of $\mathrm{THF}$ at $-78{ }^{\circ} \mathrm{C}$ under argon. (Note: the enolate solution flask is not rinsed with additional solvent during cannula transfer.) The resulting mixture was stirred for $10 \mathrm{~min}$ at $-78{ }^{\circ} \mathrm{C}$, then for $10 \mathrm{~min}$ in a room temperature water bath, and then transferred to a separatory funnel with $50 \mathrm{~mL}$ of ether and $150 \mathrm{~mL}$ of saturated sodium bicarbonate solution. The aqueous layer was separated, diluted with $50 \mathrm{~mL}$ of water, and extracted with $50 \mathrm{~mL}$ of $\mathrm{CH}_{2} \mathrm{Cl}_{2}$. The combined organic layers were partially dried over $\mathrm{Na}_{2} \mathrm{SO}_{4}$, filtered, and concentrated at reduced pressure to give a wet, yelloworange oil. This crude material was partitioned between $50 \mathrm{~mL}$ of $\mathrm{CH}_{2} \mathrm{Cl}_{2}$ and $25 \mathrm{~mL}$ of saturated sodium bicarbonate solution in a $200-\mathrm{mL}$ round-bottomed flask, and $m$-CPBA (Aldrich, 57-86\%, $2.27 \mathrm{~g}, 7.5-11.3 \mathrm{mmol}, 1.5-2.3$ equiv) was added in one portion. The resulting mixture was stirred vigorously for $20 \mathrm{~min}$, then transferred to a separatory funnel and separated. The aqueous layer was extracted with $25 \mathrm{~mL}$ of $\mathrm{CH}_{2} \mathrm{Cl}_{2}$. The combined organic layers were dried over $\mathrm{Na}_{2} \mathrm{SO}_{4}$, filtered, and concentrated under reduced pressure at room temperature to give a crude, yellow oil. Purification by flash column chromatography on $109 \mathrm{~g}$ of silica gel (gradient elution with 5-10\% ether/hexanes) provided $0.94 \mathrm{~g}$ of 27 (86\%) as a pale yellow oil. TLC: $R f 0.32$ (95:5 hexanes/EtOAc). $\quad$ IR (film): 2938.0, 1660.1, 1611.7, 1301.8. $\mathbf{1}_{\mathbf{H}-\mathbf{N M R}}$ (400 MHz, CDCl3): $\delta 5.99$ (app s, 1H), 5.91 (app d, 1H, $J=1.9 \mathrm{~Hz}$ ), 5.27 (app s, 1H), 2.43-2.62 (m, 4H) 2.02-2.10 (m, 1H), 1.83-1.92 (m, 2H), 1.65 (hept, $1 \mathrm{H} J=7.1 \mathrm{~Hz}), 1.31-1.49$ (m, 2H), 
1.02 (s, 3H), 0.99 (d, 3H, $J=6.6 \mathrm{~Hz}$ ), 0.94 (d, 3H, $J=6.6 \mathrm{~Hz}$ ); ${ }^{13}$ C-NMR (100 MHz, CDCl3): $\delta$ 195.6, 173.4, 148.1, 123.3, 121.7, 60.9, 49.7, 41.5, 34.8, 31.5, 28.9, 27.8, 24.8, 23.5, 22.9; ESIMS m/z (rel int): (pos) $256.9\left([\mathrm{M}+\mathrm{K}]^{+}, 100\right), 241.0\left([\mathrm{M}+\mathrm{Na}]^{+}, 95\right), 219.1\left([\mathrm{M}+\mathrm{H}]^{+}, 55\right)$. HRMS (EI) $\mathrm{m} / \mathrm{z} 219.1747\left(\mathrm{M}+\mathrm{H}^{+}\right)$, calcd for $\mathrm{C}_{15} \mathrm{H}_{22} \mathrm{O} 218.1671$

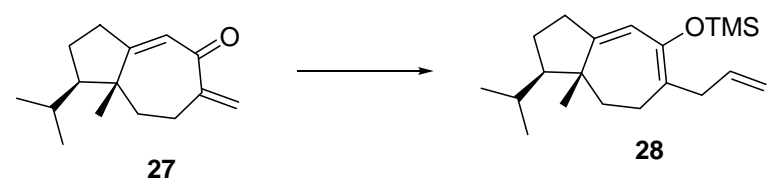

8-Allyl-12 $\beta$-isopropyl-11 $\beta$-methyl-( $\left.\Delta^{1,2}\right)$-hydroazulen-3-one $\left(\Delta^{3,8}\right)$-trimethylsilyl enol ether 28. In a base-washed $100 \mathrm{~mL}$ round bottom flask, CuI $(1.22 \mathrm{~g}, 6.42 \mathrm{mmol}, 1.5$ equiv) is suspended in $15.7 \mathrm{~mL}$ THF (Aldrich SureSeal) and cooled to $-78^{\circ} \mathrm{C}$. Vinyl magnesium bromide (1.0 $\mathrm{M}$ in THF, $12.85 \mathrm{~mL}, 12.85 \mathrm{mmol}, 3.0$ equiv) is added slowly via syringe, then the flask transferred to a $-44^{\circ} \mathrm{C}$ bath and stirred for $45 \mathrm{~min}$. Over this time, the reaction mixture turns from an orange-brown slurry to an olive-gray slurry. In a separate $100 \mathrm{~mL}$ conical flask, exomethylene hydroazulenone 27 (935 mg, $4.28 \mathrm{mmol}$, 1.0 equiv)is azeotroped $1 \times$ from $\mathrm{PhH} a t \mathrm{rt}$ then dissolved in $15 \mathrm{~mL}$ THF. Freshly distd TMSCl ( $2.45 \mathrm{~mL}, 19.27 \mathrm{mmol}, 4.5$ equiv) is added to the hydroazulenone via syringe and the solution is mixed for 2 min. The cuprate flask is cooled to $-78{ }^{\circ} \mathrm{C}$ and HMPA (3.35 mL, $19.27 \mathrm{mmol}, 4.5$ equiv) is added via syringe. The hydroazulenone/TMSCl solution is cooled to $-78{ }^{\circ} \mathrm{C}$ then transferred via canula to the cuprate flask with vigorous stirring. The hydroazulenone flask is rinsed $2 \times 5 \mathrm{~mL}$ THF. The resulting olive slurry is stirred for $25 \mathrm{~min}$ at $-78{ }^{\circ} \mathrm{C}$, then freshly distd $\mathrm{Et}_{3} \mathrm{~N}$ ( $3.00 \mathrm{~mL}, 21.41 \mathrm{mmol}, 5.0$ equiv) is added via syringe. The flask is removed from the bath and allowed to warm to rt. The resulting black reaction mixture is cooled to $0{ }^{\circ} \mathrm{C}$, quenched with $20 \mathrm{~mL}$ satd aq $\mathrm{NH}_{4} \mathrm{Cl}$ (adjusted to $\mathrm{pH} 8$ with $\mathrm{NH}_{4} \mathrm{OH}$ ), and allowed to warm to rt. The mixture is poured into $100 \mathrm{~mL}$ hexanes and more $\mathrm{NH}_{4} \mathrm{Cl} / \mathrm{NH}_{4} \mathrm{OH}$ solution is added. The layers are separated and the aq layer is extracted $2 \times$ hexanes. The combined organic layers are washed $1 \times \mathrm{NH}_{4} \mathrm{Cl} / \mathrm{NH}_{4} \mathrm{OH}, 1 \times \mathrm{H}_{2} \mathrm{O}, 1$ $\times$ brine, dried $\left(\mathrm{Na}_{2} \mathrm{SO}_{4}\right)$, filtered, and evaporated to yield the crude trimethylsilyl enol ether $\mathbf{2 8}$ as a yellow oil (1.364 g, 100\%, 95\% purity by NMR). The crude product is best carried on directly to the next step, but can also be purified by silica flash chromatography (199:1 hexanes/EtOAc, 64\%). TLC: $R f 0.68$ (9:1 hexanes/EtOAc). IR (film): 3075, 2957, 2870, 1654, 1637, 1251, 1153, 902, 842, 753. 1H-NMR (500 MHz, CDCl3): $\delta 5.77$ (ddt, $1 \mathrm{H}, J=16.9,10.1,6.8, \mathrm{C6}-\mathrm{H}$ ), 5.46 (app t, $1 \mathrm{H}, J=1.8 \mathrm{~Hz}, \mathrm{C} 2-\mathrm{H}), 5.01$ (app dq, $1 \mathrm{H}, J=17.0,1.6 \mathrm{~Hz}, \mathrm{C} 5-\mathrm{H}_{\mathrm{Z}}$ ), 4.96 (dm, 1H, $J=$ $\left.9.9 \mathrm{~Hz}, \mathrm{C} 5-\mathrm{H}_{E}\right), 2.85\left(\mathrm{~m}, 2 \mathrm{H}, \mathrm{C} 7-\mathrm{H}_{2}\right), 2.38\left(\mathrm{~m}, 2 \mathrm{H}, \mathrm{C} 14-\mathrm{H}_{2}\right), 2.17$ (m, 2H, C9- $\left.\mathrm{H}_{2}\right), 1.94(\mathrm{dt}, 1 \mathrm{H}$, $\left.J=13.5,5.1 \mathrm{~Hz}, \mathrm{C} 10-\mathrm{H}_{\beta}\right), 1.81\left(\mathrm{~m}, 1 \mathrm{H}, \mathrm{C} 13-\mathrm{H}_{\alpha}\right), 1.66$ (app sxt, $\left.1 \mathrm{H}, J=6.8 \mathrm{~Hz}, \mathrm{C} 18-\mathrm{H}\right), 1.46$ (obsc m, 1H, C10- $\mathrm{H}_{\alpha}$ ), 1.41 (obsc m, $1 \mathrm{H}, \mathrm{C} 13-\mathrm{H}_{\beta}$ ), 1.39 (ddd, $1 \mathrm{H}, J=12.8,7.3,5.7 \mathrm{~Hz}, \mathrm{C} 12-\mathrm{H}$ ), 0.96 (d, 3H, $\left.J=6.7 \mathrm{~Hz}, \mathrm{C} 19-\mathrm{H}_{3}\right), 0.92$ (d, 3H, $\left.J=6.7 \mathrm{~Hz}, \mathrm{C} 20-\mathrm{H}_{3}\right), 0.86\left(\mathrm{~s}, 3 \mathrm{H}, \mathrm{C} 17-\mathrm{H}_{3}\right), 0.16$ (s, 9H, $\left({\left.\left.\mathrm{C} 23-\mathrm{H}_{3}\right)_{3}\right) .}^{13} \mathrm{C}-\mathrm{NMR}\left(125 \mathrm{MHz}, \mathrm{CDCl}_{3}\right): \delta 157.1\right.$ (C1), 141.3 (C3), 137.1 (C6), 119.8 (C3), 117.8 (C2), 114.6 (C5), 58.2 (C12), 46.9 (C11), 38.1 (C10), 37.6 (C7), 32.3 (C14), 28.5 (C9, C18), 27.8 (C13), 23.7 (C19), 22.5 (C20), 15.7 (C17), 0.7 (C233). ESI-MS m/z (rel int): (pos) $269.2\left([\mathrm{M}+\mathrm{Na}]^{+}, 100\right), 247.1\left([\mathrm{M}+\mathrm{H}]^{+}, 5\right)$. 

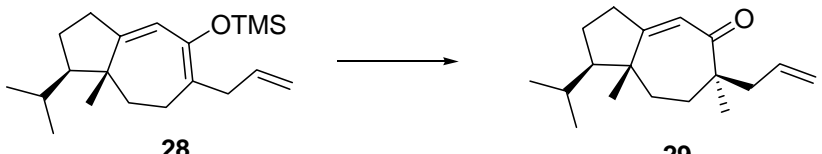

29

8$\beta$-Allyl-8 $\alpha, 11 \beta$-dimethyl-12 $\beta$-isopropyl-( $\left.\Delta^{\mathbf{1 , 2}}\right)$-hydroazulen-3-one 29 . In a $50 \mathrm{~mL}$ conical flask, the crude silyl enol 28 (1.364 g, $4.28 \mathrm{mmol}, 1.0$ equiv) is azeotroped $2 \times$ from $\mathrm{PhH}$, then dissolved in $21.4 \mathrm{~mL}$ THF (Aldrich SureSeal) to form a light yellow solution which is cooled to $0{ }^{\circ} \mathrm{C}$. Methyl lithium (1.3 $\mathrm{M}$ in $\mathrm{Et}_{2} \mathrm{O}, 4.94 \mathrm{~mL}, 6.42 \mathrm{mmol}, 1.5$ equiv) is added via syringe and the orange brown solution is stirred for $10 \mathrm{~min}$ at $0{ }^{\circ} \mathrm{C}$, then cooled to $-78{ }^{\circ} \mathrm{C}$. HMPA (3.83 mL, $21.41 \mathrm{mmol}, 5.0$ equiv) then methyl iodide $(1.33 \mathrm{~mL}, 21.41 \mathrm{mmol}, 5.0$ equiv) are added via syringe and the flask is removed from the bath and allowed to warm to rt. After $20 \mathrm{~min}$, the reaction mixture is poured into satd aq $\mathrm{NaHCO}_{3}$, diluted with $\mathrm{H}_{2} \mathrm{O}$ to dissolve precipitated solids, then extracted $3 \times \mathrm{Et}_{2} \mathrm{O}$. The combined organic extracts are washed $1 \times \mathrm{H}_{2} \mathrm{O}, 1 \times$ brine, dried $\left(\mathrm{MgSO}_{4}\right)$, filtered, and evaporated to yield the crude product as a yellow liquid $(1.120 \mathrm{~g})$. Purification by silica flash chromatography (99:1 hexanes/EtOAc) yields $8 \beta$-allyl-8 $\alpha$-methyl hydroazulenone $\mathbf{2 9}$ as a clear oil (862 $\mathrm{mg}, 77 \%$ for two steps). TLC: $R f$ 0.29 (9:1 hexanes/EtOAc). IR (film): 3073, 2959, 2871, 1655 (C=O), 1465, 1378, 1232, 1001, 910. $\mathbf{1}_{\mathbf{H}-}$ NMR (500 MHz, CDCl3): $\delta 5.80$ (app ddt, 1H, $J=15.4,11.2,7.6$ Hz, C6-H), 5.68 (app t, 1H, $J$ $=1.8 \mathrm{~Hz}, \mathrm{C} 2-\mathrm{H}$ ), 5.041 (obsc dm, $1 \mathrm{H}, J=11.3 \mathrm{~Hz}, \mathrm{C} 5-\mathrm{H}_{E}$ ), 5.036 (obsc dm, $1 \mathrm{H}, J=15.9 \mathrm{~Hz}$, C5-Hz), 2.52 (app ddt, $1 \mathrm{H}, J=17.5,8.3,1.8 \mathrm{~Hz}, \mathrm{C} 14-\mathrm{H}_{\beta}$ ), 2.45 (app dd, $1 \mathrm{H}, J=13.7,6.8 \mathrm{~Hz}$, C7-H $\mathrm{H}_{\beta}$ ), 2.36 (dtd, $1 \mathrm{H}, J=18.4,9.3,1.7 \mathrm{~Hz}, \mathrm{C} 14-\mathrm{H}_{\alpha}$ ), 2.19 (dd, $1 \mathrm{H}, J=13.8,7.9 \mathrm{~Hz}, \mathrm{C} 7-\mathrm{H}_{\alpha}$ ), 2.01 (ddd, $1 \mathrm{H}, J=14.7,12.6,2.1 \mathrm{~Hz}, \mathrm{C} 9-\mathrm{H}_{\beta}$ ), 1.93 (ddd, $1 \mathrm{H}, J=14.4,7.0,2.1 \mathrm{~Hz}, \mathrm{C} 10-\mathrm{H}_{\beta}$ ), 1.87 (obsc m, 1H, C13- $\mathrm{H}_{\mathrm{a}}$ ), 1.85 (obsc m, 1H, C10- $\mathrm{H}_{\alpha}$ ), 1.66 (app oct, $1 \mathrm{H}, J=6.7 \mathrm{~Hz}, \mathrm{C} 18-\mathrm{H}$ ),

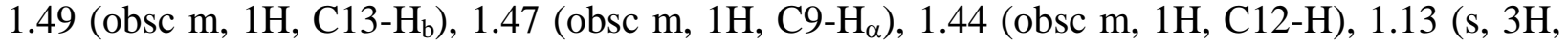
C16-H $\left.{ }_{3}\right), 0.99$ (d, 3H, $\left.J=6.7 \mathrm{~Hz}, \mathrm{C} 19-\mathrm{H}_{3}\right), 0.94$ (s, 3H, C17-H $), 0.91$ (d, 3H, $J=6.7 \mathrm{~Hz}, \mathrm{C} 20-$ $\mathrm{H}_{3}$ ). 13C-NMR (125 MHz, CDCl3): $\delta 208.2$ (C3), 167.2 (C1), 135.4 (C6), 122.0 (C2), 117.4 (C5), 57.3 (C12), 49.8 (C8), 49.3 (C11), 43.7 (C7), 33.6 (C10), 32.0 (C14), 31.4 (C9), 28.0 (C18), 25.7 (C13), 24.8 (C16), 24.1 (C19), 22.0 (C20), 20.7 (C17). ESI-MS m/z (rel int): (pos) $283.1\left([\mathrm{M}+\mathrm{Na}]^{+}, 50\right), 261.1\left([\mathrm{M}+\mathrm{H}]^{+}\right.$, 5). HRMS (EI) m/z $261.2229\left(\mathrm{M}+\mathrm{H}^{+}\right)$, calcd for $\mathrm{C}_{18} \mathrm{H}_{28} \mathrm{O}$ 260.2140

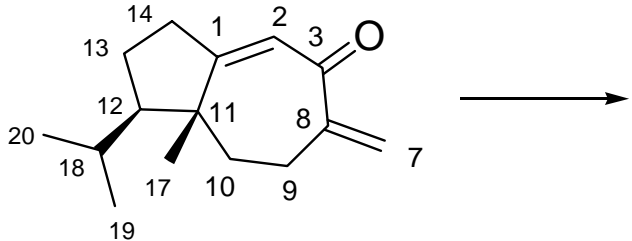

27

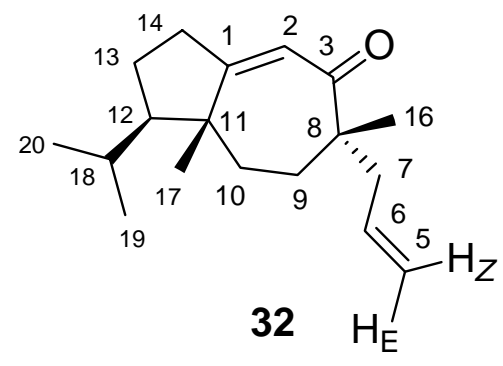
8$\alpha$-Allyl-8 $\beta, 11 \beta$-dimethyl-12 $\beta$-isopropyl- $\left(\Delta^{1,2}\right)$-hydroazulen-3-one 32: A 25 -mL, roundbottomed flask equipped with a reflux condenser was charged with Wilkinson's catalyst (1 mg, $0.001 \mathrm{mmol}, 0.01$ equiv). A solution of enone 27 (0.01 $\mathrm{M}$ in benzene, $10 \mathrm{~mL}, 0.1 \mathrm{mmol}, 1.0$ equiv) was added, followed by dimethylphenylsilane $(0.15 \mathrm{~mL}, 1.0 \mathrm{mmol}, 10$ equiv), and the resulting yellow solution was heated at reflux under argon. After $20 \mathrm{~min}$, the reaction mixture was cooled to room temperature, diluted with $10 \mathrm{~mL}$ of toluene, and concentrated at reduced pressure. The resulting residue was filtered quickly through a plug of silica gel (elution with $10 \%$ ethyl acetate/hexanes) to afford $43 \mathrm{mg}$ of an orange oil, which was used without further 
purification in the next step. In a 10-mL pear-shaped flask, the crude enolsilane (43 mg) was dissolved in $1 \mathrm{~mL}$ of THF and cooled to $0{ }^{\circ} \mathrm{C}$ under argon. Methyllithium ( $1 \mathrm{M}$ in ether, $0.3 \mathrm{~mL}$, $0.3 \mathrm{mmol}, 3$ equiv) was added via syringe. After $15 \mathrm{~min}$, the reaction mixture was cooled to -78 ${ }^{\circ} \mathrm{C}$ and treated with allyl iodide $(91 \mu \mathrm{L}, 1.0 \mathrm{mmol}, 10$ equiv) and the reaction mixture was removed from the bath and allowed to warm to rt. After an additional $30 \mathrm{~min}$, the reaction mixture was partitioned between ethyl acetate and half-saturated sodium chloride solution. The organic layer was dried over magnesium sulfate, filtered, concentrated under reduced pressure, and purified on $5.2 \mathrm{~g}$ of silica gel (elution with $2 \%$ ethyl acetate/hexanes) to provide $18 \mathrm{mg}$ (69\% overall) of ketone 32 as a colorless oil. IR (film): 2960, 2871, 1668 (C=O), 1456, 1375, 1198, 1118, 994, 913. 1H-NMR (500 MHz, CDCl3): $\delta 5.65$ (app s, 1H, C2-H), 5.63 (obsc m, 1H, C6H), 5.04 (obsc dm, $1 \mathrm{H}, J=9.1 \mathrm{~Hz}, \mathrm{C} 5-\mathrm{H}_{E}$ ), 5.02 (obsc dm, $1 \mathrm{H}, J=16.1 \mathrm{~Hz}, \mathrm{C} 5-\mathrm{H}_{z}$ ), 2.51 (dd, $\left.1 \mathrm{H}, J=18.5,7.8 \mathrm{~Hz}, \mathrm{C} 14-\mathrm{H}_{\beta}\right), 2.39\left(\mathrm{~m}, 2 \mathrm{H}, \mathrm{C} 7-\mathrm{H}_{\alpha}, \mathrm{C} 14-\mathrm{H}_{\alpha}\right), 2.21$ (dd, $1 \mathrm{H}, J=13.5,7.7 \mathrm{~Hz}, \mathrm{C} 7-$ $\mathrm{H}_{\beta}$ ), 1.92 (obsc m, 1H, C10- $\mathrm{H}_{\alpha}$ ), $1.86\left(\mathrm{~m}, 3 \mathrm{H}, \mathrm{C} 9-\mathrm{H}_{\beta}, \mathrm{C} 10-\mathrm{H}_{\beta}, \mathrm{C} 13-\mathrm{H}_{\alpha}\right), 1.65(\mathrm{~m}, 2 \mathrm{H}, \mathrm{C} 18-\mathrm{H}$,

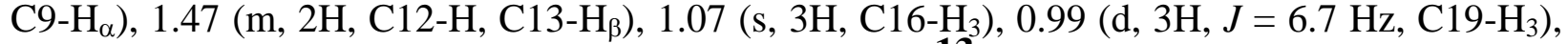
0.94 (s, 3H, C17- $\left.\mathrm{H}_{3}\right), 0.91$ (d, 3H, $\left.J=6.6 \mathrm{~Hz}, \mathrm{C} 20-\mathrm{H}_{3}\right)$. 13C-NMR (100 MHz, CDCl3): $\delta 209$ (C3, by HMBC), 166.0 (C1), 133.5 (C6), 121.5 (C2), 118.0 (C5), 57.4 (C12), 50.7(C8), 49.1 (C11), 42.8 (C7), 33.4 (C14), 32.8 (C10), 31.9 (C9), 27.9 (C18), 25.9 (C13), 24.1 (C19), 22.8 (C16), 22.0 (C20), 21.3 (C17). ESI-MS m/z (rel int): (pos) 283.1 ([M+Na $\left.]^{+}, 60\right), 260.8$ $\left([\mathrm{M}+\mathrm{H}]^{+}, 100\right)$.

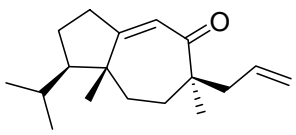

29

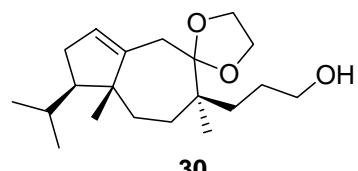

30

8 $\beta$-Allyl-8 $\alpha, 11 \beta$-dimethyl-3,3-ethylenedioxy-12 $\beta$-isopropyl- $\left(\Delta^{1,14}\right)$-hydroazulene 30 . In a 100 $\mathrm{mL}$ round bottom flask, the 8-allyl-8-methyl hydroazulenone $\mathbf{2 9}(860 \mathrm{mg}, 3.30 \mathrm{mmol}$, 1.0 equiv) is dissolved in $50 \mathrm{~mL} \mathrm{PhH}$. Ethylene glycol (5.53 mL, $99.1 \mathrm{mmol}, 30$ equiv) and $\mathrm{TsOH} \cdot \mathrm{H}_{2} \mathrm{O}$ (314 mg, $1.65 \mathrm{mmol}, 0.5$ equiv) are added and the mixture is heated to reflux under a DeanStark condenser with vigorous stirring. After $36 \mathrm{~h}$, the mixture is cooled to rt, then poured into satd aq $\mathrm{NaHCO}_{3}$ and extracted $3 \times \mathrm{Et}_{2} \mathrm{O}$. The combined organic extracts are washed $2 \times$ satd aq $\mathrm{NaHCO}_{3}, 1 \times \mathrm{H}_{2} \mathrm{O}, 1 \times$ brine, dried $\left(\mathrm{MgSO}_{4}\right)$, filtered, and evaporated to yield the crude product as a yellow oil $(999 \mathrm{mg})$. Purification by silica flash chromatography (4:1 hexanes/ $\mathrm{CH}_{2} \mathrm{Cl}_{2}$ ) yields the dioxolane as a clear oil (895 mg, 89\%). TLC: $R f 0.39\left(1: 1\right.$ hexanes/ $\left.\mathrm{CH}_{2} \mathrm{Cl}_{2}\right)$. IR (film): 2950, 2881, 1454, 1371, 1130, 1079 (C-O), 1010, 914. 1H-NMR (500 MHz, CDCl3, partially assigned by COSY): $\delta 5.76$ (dddd, $1 \mathrm{H}, J=16.9,10.2,8.1,6.7 \mathrm{~Hz}, \mathrm{C} 6-\mathrm{H}), 5.36(\mathrm{~s}, 1 \mathrm{H}$, C14-H), 5.08 (obsc dm, 1H, $J=16.9 \mathrm{~Hz}, \mathrm{C} 5-\mathrm{H}_{\mathrm{Z}}$ ), 5.06 (obsc dm, 1H, $J=9.9 \mathrm{~Hz}, \mathrm{C} 5-\mathrm{H}_{E}$ ), 4.02 (obsc m, 1H, C23/24-H), 3.96 (obsc m, 2H, C23/24-H, C23/24-H), 3.89 (obsc m, 1H, C23/24-H), 2.45 (dd, 1H, $J=14.0,6.5 \mathrm{~Hz}, \mathrm{C} 7-\mathrm{H}_{\mathrm{a}}$ ), 2.35 (obsc dm, 1H, $J=15.2 \mathrm{~Hz}, \mathrm{C} 2-\mathrm{H}_{\mathrm{a}}$ ), 2.34 (obsc m, 1H, C13- $\mathrm{H}_{\mathrm{a}}$ ), 2.22 (obsc dd, 1H, $J=14.0,8.2 \mathrm{~Hz}, \mathrm{C} 7-\mathrm{H}_{\mathrm{b}}$ ), 2.20 (obsc d, $1 \mathrm{H}, J=13.6 \mathrm{~Hz}, \mathrm{C} 2-\mathrm{H}_{\mathrm{b}}$ ), 1.92 (ddm, 1H, $J=15.7,9.9 \mathrm{~Hz}, \mathrm{C} 13-\mathrm{H}_{\mathrm{b}}$ ), 1.73 (obsc m, 1H, C9/10-H), 1.69 (obsc m, 1H, C18H), 1.65 (obsc m, 1H, C12-H), 1.44 (m, 2H, C9/10-H, C9/10-H), 1.17 (m, 1H, C9/10-H), 0.96 (d, $3 \mathrm{H}, J=6.3 \mathrm{~Hz}, \mathrm{C} 19 / 20-\mathrm{H}_{3}$ ), 0.89 (s, 3H, C17/16- $\mathrm{H}_{3}$ ), 0.88 (obsc d, 3H, $J=7.5 \mathrm{~Hz}, \mathrm{C} 20 / 19-\mathrm{H}_{3}$ ), 0.81 (s, 3H, C16/17- $\mathrm{H}_{3}$ ). 13C-NMR (100 MHz, CDCl 3$)$ : $\delta 147.1$ (q), $135.2(\mathrm{o}), 126.4(\mathrm{o})$, 117.5 (e), 112.8 (q), 65.1 (e), 64.5 (e), 54.0 (o), 49.7 (q), 44.6 (q), 38.3 (e), 35.5 (e), 32.4 (e), 32.1 (e), 29.7 (o), 29.3 (e), 23.1 (o), 22.9 (o), 21.0 (o), 20.7 (o). ESI-MS m/z (rel int): (pos) $327.1\left([\mathrm{M}+\mathrm{Na}]^{+}, 30\right)$; (neg) $339.0\left([\mathrm{M}+\mathrm{Cl}]^{-}, 50\right)$. HRMS (EI) m/z $305.2481\left(\mathrm{M}+\mathrm{H}^{+}\right)$, calcd for 
$\mathrm{C}_{20} \mathrm{H}_{32} \mathrm{O}_{2}$ 304.2402. In a $100 \mathrm{~mL}$ round bottom flask, the dioxolane (892 mg, $2.93 \mathrm{mmol}, 1.0$ equiv) is azeotroped $2 \times$ from $\mathrm{PhH}$ then dissolved in $15 \mathrm{~mL}$ THF (Aldrich SureSeal) and cooled to $0{ }^{\circ} \mathrm{C}$. A freshly prepared stock solution of 9-BBN (0.5 M in THF, $17.6 \mathrm{~mL}, 8.79 \mathrm{mmol}, 3.0$ equiv) is added via syringe and the reaction is removed from the bath and allowed to warm to rt. After $3.5 \mathrm{~h}$, the mixture is cooled to $0{ }^{\circ} \mathrm{C}$ and $\mathrm{NaOH}(3 \mathrm{~N}$ aq, $9.67 \mathrm{~mL}, 29 \mathrm{mmol}, 9.9$ equiv) is added. $\mathrm{H}_{2} \mathrm{O}_{2}(30 \% \mathrm{aq}, 2.99 \mathrm{~mL}, 29 \mathrm{mmol}, 9.9$ equiv) is added dropwise (CAUTION! Evolves gas!) then the mixture is allowed to warm to rt with vigorous stirring. The mixture is poured into $1 \mathrm{~N}$ aq $\mathrm{NaOH}$ and extracted $3 \times \mathrm{Et}_{2} \mathrm{O}$. The combined organic extracts are washed $1 \times \mathrm{H}_{2} \mathrm{O}, 1 \times$ brine, dried $\left(\mathrm{MgSO}_{4}\right)$, filtered, and evaporated to yield the crude product as a clear oil (1.879 g). Purification by silica flash chromatography (4:1 hexanes/EtOAc) yields the alcohol 30 as a clear viscous oil (927 mg, 98\%). TLC: $R f 0.25$ (2:1 hexanes/EtOAc). IR (film): 3432 (br, O-H), 2948, 2880, 1470, 1453, 1371, 1298, 1074 (C-O), 1002, 947. 1H-NMR (500 MHz, CDCl3, partially assigned by COSY): $\delta 5.36(\mathrm{~s}, 1 \mathrm{H}, \mathrm{C} 14-\mathrm{H}), 4.03(\mathrm{~m}, 1 \mathrm{H}, \mathrm{C} 23 / 24-\mathrm{H}), 3.98-3.87(\mathrm{~m}, 3 \mathrm{H}$, C23/24-H, C23/24-H, C23/24-H), 3.67 (br s, 1H, C5-H), 2.36 (obsc dm, 1H, J = 12.8 Hz, C2$\mathrm{H}_{\mathrm{a}}$ ), 2.35 (obsc m, $1 \mathrm{H}, \mathrm{C} 13-\mathrm{H}_{\mathrm{a}}$ ), 2.18 (d, $1 \mathrm{H}, J=13.5 \mathrm{~Hz}, \mathrm{C} 2-\mathrm{H}_{\mathrm{b}}$ ), 1.92 (ddm, $1 \mathrm{H}, J=15.7,10.1$ $\mathrm{Hz}, \mathrm{C} 13-\mathrm{H}_{\mathrm{b}}$ ), 1.76-1.61 (m, 4H, C7/9/10-H, C18-H, C12-H, C7/9/10-H), 1.53-1.41 (m, 3H, C6$\left.\mathrm{H}_{\mathrm{a}}, \mathrm{C} 7 / 9 / 10-\mathrm{H}, \mathrm{C} 7 / 9 / 10-\mathrm{H}\right), 1.32$ (m, 2H, C6- $\left.\mathrm{H}_{\mathrm{b}}, \mathrm{C} 7 / 9 / 10-\mathrm{H}\right), 1.18$ (dd, $1 \mathrm{H}, J=15.1,8.5 \mathrm{~Hz}$, C7/9/10-H), 0.96 (d, 3H, $J=6.3 \mathrm{~Hz}, \mathrm{C} 19 / 20-\mathrm{H}_{3}$ ), 0.88 (s, 3H, C17/16- $\mathrm{H}_{3}$ ), 0.88 (obsc d, 3H, $J=$ $\left.6.1 \mathrm{~Hz}, \mathrm{C} 20 / 19-\mathrm{H}_{3}\right), 0.83$ (s, 3H, C16/17- $\mathrm{H}_{3}$ ). 13C-NMR (100 MHz, CDCl 3 ): $\delta 147.1$ (q), 126.4 (o), 113.2 (q), 65.1 (e), 64.4 (e), 63.9 (e), 54.0 (o), 49.6 (q), 44.1 (q), 35.5 (e), 32.3 (e), 32.1 (e), 29.7 (o), 29.6 (e), 29.1 (e), 27.0 (e), 23.0 (o), 22.9 (o), 20.8 (o), 20.8 (o). ESI-MS m/z (rel int): (pos) $345.1\left([\mathrm{M}+\mathrm{Na}]^{+}\right.$, 55), $319.1\left([\mathrm{M}+\mathrm{H}]^{+}, 40\right)$; (neg) $356.9\left([\mathrm{M}+\mathrm{Cl}]^{-}, 100\right)$. HRMS (EI) $\mathrm{m} / \mathrm{z} 323.2586\left(\mathrm{M}+\mathrm{H}^{+}\right)$, calcd for $\mathrm{C}_{20} \mathrm{H}_{34} \mathrm{O}_{3} 322.2508$

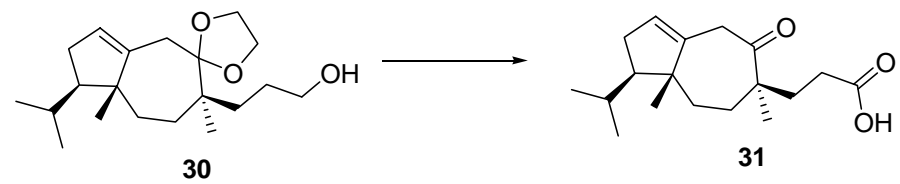

8 $\beta$-(3'-Carboxyethyl)-8 $\alpha, 11 \beta$-dimethyl-12 $\beta$-isopropyl-( $\left.\Delta^{1,14}\right)$-hydroazulen-3-one 31. In a 25 $\mathrm{mL}$ round bottom flask, the alcohol 30 ( $25.5 \mathrm{mg}, 79.1 \mu \mathrm{mol}, 1.0$ equiv) is dissolved in $800 \mu \mathrm{L}$ acetone (HPLC grade) and cooled to $0{ }^{\circ} \mathrm{C}$ under air. Freshly prepared Jones reagent (dissolve

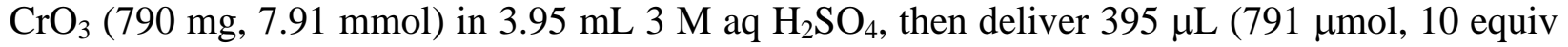
$\mathrm{CrO}_{3}$ ) of solution) is added to the alcohol and the reaction is stirred $40 \mathrm{~min}$ at $0{ }^{\circ} \mathrm{C}$, then removed from the bath and allowed to warm to rt. The resulting orange slurry is quenched with $1 \mathrm{~mL} i-\mathrm{PrOH}$, forming a light green clear solution after $5 \mathrm{~min}$. The mixture is poured into $\mathrm{H}_{2} \mathrm{O}$ and extracted $3 \times$ EtOAc. The combined organic extracts are washed $1 \times \mathrm{H}_{2} \mathrm{O}, 1 \times$ brine, dried $\left(\mathrm{MgSO}_{4}\right)$, filtered, and evaporated to yield the crude product as a white solid (25.3 $\left.\mathrm{mg}\right)$. Purification by silica flash chromatography (85:15:1 hexanes/EtOAc/AcOH) yields the carboxy ketone 31 as a white solid (14.3 mg, 62\%). TLC: $R f 0.18$ (50:50:1 hexanes/EtOAc/AcOH). mp (uncorr): 135.7-137.3 ${ }^{\circ} \mathrm{C}$. IR (film): 3500-2300 (br, COO-H), 2955, 1707 (C=O), 1462, 1423, 1379, 1294, 1266, 1213, 1073, 1044. 1H-NMR (500 MHz, CDCl 3 ): $\delta 5.44$ (s, 1H, C14-H), 3.45 (br d, $1 \mathrm{H}, J=11.6 \mathrm{~Hz}, \mathrm{C} 2-\mathrm{H}_{\mathrm{a}}$ ), 2.96 (d, $1 \mathrm{H}, J=11.7 \mathrm{~Hz}, \mathrm{C} 2-\mathrm{H}_{\mathrm{b}}$ ), 2.36 (obsc ddd, $1 \mathrm{H}, J=$ 16.5, 10.6, $5.8 \mathrm{~Hz}, \mathrm{C6}-\mathrm{H}_{\mathrm{a}}$ ), 2.30 (obsc ddd, $1 \mathrm{H}, J=16.4,8.3,2.9 \mathrm{~Hz}, \mathrm{C} 13-\mathrm{H}_{\mathrm{a}}$ ), 2.23 (obsc ddd, $1 \mathrm{H}, J=16.4,10.6,5.7 \mathrm{~Hz}, \mathrm{C} 6-\mathrm{H}_{\mathrm{b}}$ ), 1.95 (obsc m, 2H, C9- $\mathrm{H}_{\mathrm{a}}, \mathrm{C} 13-\mathrm{H}_{\mathrm{b}}$ ), 1.90 (obsc m, 2H, C7- $\mathrm{H}_{\mathrm{a}}$, C10- $\mathrm{H}_{\mathrm{a}}$ ), 1.73 (m, 2H, C7-H, $\mathrm{C} 18-\mathrm{H}$ ), 1.52 (obsc m, 1H, C9- $\mathrm{H}_{\mathrm{b}}$ ), 1.50 (obsc m, 1H, C12-H), 1.43 (app t, $1 \mathrm{H}, J=12.8 \mathrm{~Hz}, \mathrm{C} 10-\mathrm{H}_{\mathrm{b}}$ ), 1.05 (s, 3H, C16- $\mathrm{H}_{3}$ ), 1.00 (s, 3H, C17- $\mathrm{H}_{3}$ ), 0.97 (d, 3H, $J$ $\left.=6.5 \mathrm{~Hz}, \mathrm{C} 19-\mathrm{H}_{3}\right), 0.88\left(\mathrm{~d}, 3 \mathrm{H}, J=6.6 \mathrm{~Hz}, \mathrm{C} 20-\mathrm{H}_{3}\right) .{ }^{13} \mathrm{C}-\mathrm{NMR}(100 \mathrm{MHz}, \mathrm{CDCl} 3): \delta 212.3$ 
(C3), 179.4 (C5), 143.6 (C1), 127.1 (C14), 58.3 (C12), 50.3 (C11), 49.6 (C8), 42.4 (C2), 36.6 (C10), 36.2 (C13), 34.7 (C7), 33.0 (C9), 30.0 (C18), 29.3 (C6), 23.5 (C19), 23.3 (C20), 21.0 (C16), 17.7 (C17). ESI-MS m/z (rel int): (pos) 315.1 ([M+Na $\left.]^{+}, 100\right)$; (neg) 326.9 ([M+Cl] $]^{-}$, 35), $290.9\left([\mathrm{M}-\mathrm{H}]^{-}, 100\right)$.
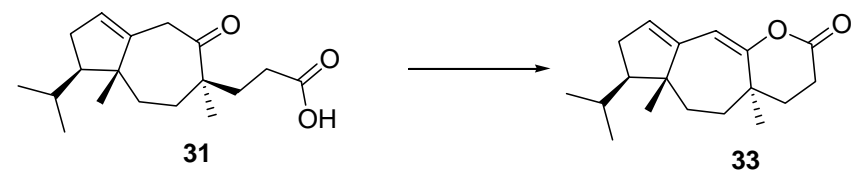

8 $\beta$-(3'-Carboxyethyl)-8 $\alpha, 11 \beta$-dimethyl-12 $\beta$-isopropyl-( $\left(\Delta^{1,14}, \Delta^{2,3}\right)$-hydroazulen-3-one dienol lactone 33. In a $25 \mathrm{~mL}$ conical flask are placed the carboxy ketone $\mathbf{3 1}$ (13.2 mg, $45.1 \mu \mathrm{mol}, 1.0$ equiv) and NaOAc (5.6 mg, $67.7 \mu \mathrm{mol}, 1.5)$, then $2.25 \mathrm{~mL} \mathrm{Ac}_{2} \mathrm{O}$ is added and the mixture is heated to reflux under a condenser for $80 \mathrm{~min}$. The resulting light yellow cloudy solution is cooled to rt and the $\mathrm{Ac}_{2} \mathrm{O}$ is evaporated. The residue is taken up in $\mathrm{Et}_{2} \mathrm{O}$, washed $1 \times$ satd aq $\mathrm{NaHCO}_{3}, 1 \times \mathrm{H}_{2} \mathrm{O}, 1 \times$ brine, dried $\left(\mathrm{MgSO}_{4}\right)$, filtered, and evaporated to yield the crude product as a yellow oil (13.8 mg). Purification by silica flash chromatography (19:1 hexanes/EtOAc) yields dienol lactone 33 as a clear oil (7.3 mg, 59\%). TLC: $R f \quad 0.52$ (66:33:1 hexanes/EtOAc/AcOH), Rf 0.38 (4:1 hexanes/EtOAc). IR (film): 2929, 1752 (C=O), 1451, 1341, 1246, 1212, 1167, 1102, 1080 (C-O), 880. 1H-NMR (500 MHz, CDCl3, partially assigned by COSY): $\delta 5.88(\mathrm{~s}, 1 \mathrm{H}, \mathrm{C} 2-\mathrm{H}), 5.51$ (s, 1H, C14-H), $2.65\left(\mathrm{ABX}_{2}\right.$ obsc ddd, $1 \mathrm{H}, J=$ 17.6, 10.8, $\left.6.5 \mathrm{~Hz}, \mathrm{C} 6-\mathrm{H}_{\mathrm{a}}\right), 2.59\left(\mathrm{ABX}_{2}\right.$ obsc ddd, $\left.1 \mathrm{H}, J=17.8,6.5,4.8 \mathrm{~Hz}, \mathrm{C6}-\mathrm{H}_{\mathrm{b}}\right), 2.39(2.39$, $1 \mathrm{H}, J=17.1,7.8,3.2 \mathrm{~Hz}, \mathrm{C} 13-\mathrm{H}_{\mathrm{a}}$ ), 2.02 (ddm, $1 \mathrm{H}, J=17.1,10.3 \mathrm{~Hz}, \mathrm{C} 13-\mathrm{H}_{\mathrm{b}}$ ), 1.94 (obsc m, 2H, C9/10-H, C9/10-H), 1.88 (obsc m, 1H, C7-H ), 1.78 (obsc m, 1H, C18-H), 1.75 (obsc m, 1H, C9/10-H), 1.60 (obsc m, 1H, C12-H), 1.58 (obsc m, 1H, C7-Hb), 1.50 (dd, 1H, J = 14.4, 7.3 Hz, C9/10-H), 1.19 (s, 3H, C16/17-H $), 1.00$ (d, 3H, $J=6.5$ Hz, C19/20-H $), 0.95$ (s, 3H, C17/16$\mathrm{H}_{3}$ ), 0.92 (d, 3H, $\left.J=6.6 \mathrm{~Hz}, \mathrm{C} 20 / 19-\mathrm{H}_{3}\right)$. 13C-NMR (100 MHz, CDCl3): $\delta$ 169.1, 154.3, 145.7, 129.6, 108.6, 58.3 (br), 49.4 (br), 37.2, 35.9, 34.9, 34.0, 29.3, 27.4, 23.8, 23.3, 23.0, 17.9. ESI-MS m/z (rel int): (pos) 297.1 ([M+Na $]^{+}$, 95); (neg) 309.0 ([M+Cl] $\left.]^{-}, 20\right)$.
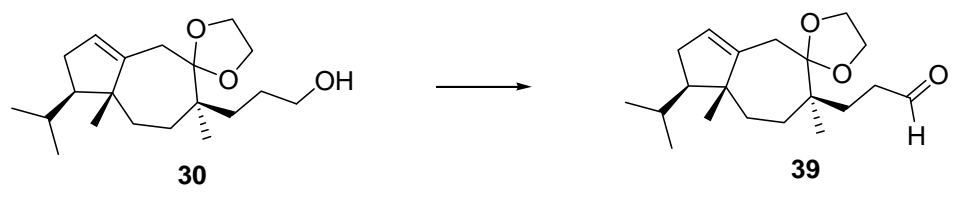

8 $\alpha, 11 \beta$-Dimethyl-3,3-ethylenedioxy-8 $\beta$-(2'-formylethyl)-12 $\beta$-isopropyl-( $\left.\Delta^{1,14}\right)$-hydroazulene 39. In a $100 \mathrm{~mL}$ round bottom flask, the alcohol 30 (990 mg, $3.07 \mathrm{mmol}, 1.0$ equiv) is dissolved in $20 \mathrm{~mL} \mathrm{CH} \mathrm{Cl}_{2}$ and cooled to $0{ }^{\circ} \mathrm{C}$. The Dess-Martin periodinane (Acros Organics, $15 \mathrm{wt} \%$ in $\mathrm{CH}_{2} \mathrm{Cl}_{2}, 13.2 \mathrm{~mL}, 4.60 \mathrm{mmol}, 1.5$ equiv) is added via syringe and the reaction mixture is removed from the bath and allowed to warm to rt during which time the clear solution becomes cloudy white. After $2 \mathrm{~h}$, the reaction mixture is washed $1 \times 1 \mathrm{~N}$ aq $\mathrm{NaOH}$. The aq layer is back extracted $2 \times \mathrm{CH}_{2} \mathrm{Cl}_{2}$ and the combined organic layers are washed $1 \times \mathrm{H}_{2} \mathrm{O}, 1 \times$ brine, dried $\left(\mathrm{MgSO}_{4}\right)$, filtered, and evaporated to yield the crude product as a clear oil (939 $\left.\mathrm{mg}\right)$. Purification by silica flash chromatography (9:1 hexanes/EtOAc) yields aldehyde 39 as a clear oil (816 mg, 83\%). TLC: $R f 0.52$ (2:1 hexanes/EtOAc). IR (film): 2950, 1726 (C=O), 1470, 1372, 1112, 1072 (C-O), 1011, 949. 1H-NMR (500 MHz, CDCl3): $\delta 9.81$ (app t, $1 \mathrm{H}, J=1.7 \mathrm{~Hz}, \mathrm{C} 5-\mathrm{H})$, 5.37 (s, 1H, C14-H), 4.04 (td, 1H, $J=6.6,4.8 \mathrm{~Hz}, \mathrm{C} 23 / 24-\mathrm{H}), 3.98$ (td, $1 \mathrm{H}, J=7.1,4.7 \mathrm{~Hz}$, C23/24-H), 3.94 (q, 1H, $J=7.0 \mathrm{~Hz}, \mathrm{C} 23 / 24-\mathrm{H}), 3.88$ (q, 1H, $J=6.8 \mathrm{~Hz}, \mathrm{C} 23 / 24-\mathrm{H}$ ), 2.48 (dddd, 
$1 \mathrm{H}, J=16.9,11.4,5.4,1.6 \mathrm{~Hz}, \mathrm{C} 6-\mathrm{H}_{\mathrm{a}}$ ), 2.354 (obsc d, 1H, $J=12.8 \mathrm{~Hz}, \mathrm{C} 2-\mathrm{H}_{\mathrm{a}}$ ), 2.345 (obsc m, $1 \mathrm{H}, \mathrm{C} 13-\mathrm{H}_{\mathrm{a}}$ ), 2.32 (obsc dddd, $1 \mathrm{H}, J=16.8,11.4,5.4,1.9 \mathrm{~Hz}, \mathrm{C} 6-\mathrm{H}_{\mathrm{b}}$ ), 2.20 (d, 1H, $J=13.6 \mathrm{~Hz}$,

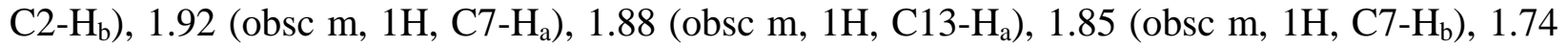
(obsc dd, 1H, $J=15.1,8.4 \mathrm{~Hz}, \mathrm{C} 10-\mathrm{H}_{\mathrm{a}}$ ), 1.70 (obsc m, 1H, C18-H), 1.62 (obsc td, 1H, $J=9.8$, 7.7 Hz, C12-H), 1.51 (dd, 1H, $J=15.3,11.6 \mathrm{~Hz}, \mathrm{C} 9-\mathrm{H}_{\mathrm{a}}$ ), 1.28 (dd, 1H, $J=15.1,11.5 \mathrm{~Hz}, \mathrm{C} 10-$ $\mathrm{H}_{\mathrm{b}}$ ), 1.11 (dd, $1 \mathrm{H}, J=15.3,8.4 \mathrm{~Hz}, \mathrm{C} 9-\mathrm{H}_{\mathrm{b}}$ ), 0.96 (d, 3H, $J=6.4 \mathrm{~Hz}, \mathrm{C} 19-\mathrm{H}$ ), 0.877 (obsc s, 3H, C17-H), 0.876 (obsc d, 3H, $J=6.4 \mathrm{~Hz}, \mathrm{C} 20-\mathrm{H}), 0.82$ (s, 3H, C16-H). 13C-NMR (100 MHz, CDCl3): $\delta 203.0$ (C5), 146.8 (C1), 126.6 (C14), 112.8 (C3), 65.1 (C23/24), 64.5 (C23/24), 54.1 (C12), 49.6 (C11), 43.7 (C8), 39.1 (C6), 35.5 (C13), 32.3 (C2), 31.9 (C10), 29.7 (C9), 29.6 (C18), 26.1 (C7), 23.0 (C19), 22.9 (C20), 20.8 (C16), 20.7 (C17). ESI-MS m/z (rel int): (pos) $343.1\left([\mathrm{M}+\mathrm{Na}]^{+}, 100\right)$. HRMS (EI) m/z $321.2431\left(\mathrm{M}+\mathrm{H}^{+}\right)$, calcd for $\mathrm{C}_{20} \mathrm{H}_{32} \mathrm{O}_{3} 320.2351$.
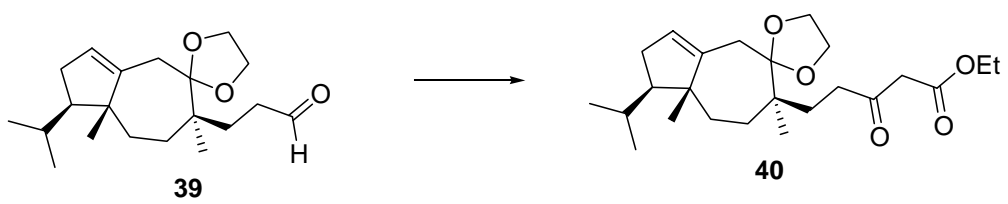

8$\beta$-(4'-Carboethoxy-3'-ketobutyl)-8 $\alpha, 11 \beta$-dimethyl-3,3-ethylenedioxy-12 $\beta$-isopropyl-( $\left.\Delta^{1,14}\right)$ hydroazulene 40. In a $100 \mathrm{~mL}$ round bottom flask, aldehyde 39 (749 mg, $2.34 \mathrm{mmol}, 1.0$ equiv) is azeotroped $1 \times$ from $\mathrm{PhH}$, then $\mathrm{SnCl}_{2}$ (222 mg, $1.17 \mathrm{mmol}, 0.5$ equiv), $23.4 \mathrm{~mL} \mathrm{CH}_{2} \mathrm{Cl}_{2}$, and ethyl diazoacetate (295 $\mu \mathrm{L}, 2.80 \mathrm{mmol}, 1.2$ equiv) are added in succession at rt. The resulting yellow solution evolves $\mathrm{N}_{2}$ for approx $15 \mathrm{~min}$. After $3.5 \mathrm{~h}$, the mixture is poured into approx $150 \mathrm{~mL}$ brine and extracted $3 \times \mathrm{Et}_{2} \mathrm{O}$. The combined organic extractes are washed $1 \times 1: 1$ $\mathrm{H}_{2} \mathrm{O}$ /brine, $1 \times$ brine, dried $\left(\mathrm{MgSO}_{4}\right)$, filtered, and evaporated to yield the crude $\beta$-keto ester $\mathbf{4 0}$ as a yellow oil (945 mg, 99\%, >95\% purity by NMR, no 41 detected). In some cases, varying amounts (15-44\%) of dioxolane deprotected $\beta, \zeta$-diketo ester $\mathbf{4 1}$ are also detected. The crude product is generally carried on directly to the next step, but can also be purified by silica flash chromatography (9:1 hexanes/EtOAc, 64\%) although separation of $\mathbf{4 0}$ and $\mathbf{4 1}$ is difficult. TLC: Rf 0.48 (plate placed under high vacuum before and after elution; double elution; 4:1 hexanes/EtOAc). IR (film): 2951, $1745(\mathrm{C}=\mathrm{O}), 1717(\mathrm{C}=\mathrm{O}), 1642,1452,1367,1306,1237$, 1164, 1087 (C-O), 1030, 948. 1H-NMR (500 MHz, CDCl3, 85:15 keto/enol form): $\delta 5.35$ (s, 1H, C14-H), 4.21 (q, 2H, $J=7.1 \mathrm{~Hz}, \mathrm{C} 25-\mathrm{H}_{2}$ ), 4.01 (app q, 1H, $J=6.0 \mathrm{~Hz}, \mathrm{C} 23 / 24-\mathrm{H}$ ), 3.96 (obsc m, 1H, C23/24-H), 3.92 (obsc app q, 1H, $J=6.7 \mathrm{~Hz}, \mathrm{C} 23 / 24-\mathrm{H}$ ), 3.87 (obsc app q, $1 \mathrm{H}, J=$ 6.7 Hz, C23/24-H), 3.47 (app s, 2H, C4-H 2 ), 2.61 (ddd, 1H, J = 17.0, 11.7, $5.1 \mathrm{~Hz}, \mathrm{C} 6-\mathrm{H}_{\mathrm{a}}$ ), 2.42 (ddd, $1 \mathrm{H}, J=17.0,11.8,5.0 \mathrm{~Hz}, \mathrm{C} 6-\mathrm{H}_{\mathrm{b}}$ ), 2.35 (obsc d, $1 \mathrm{H}, J=12.9 \mathrm{~Hz}, \mathrm{C} 2-\mathrm{H}_{\mathrm{a}}$ ), 2.32 (obsc m, 1H, C13- $\mathrm{H}_{\mathrm{a}}$ ), 2.18 (d, 1H, J = $\left.13.5 \mathrm{~Hz}, \mathrm{C} 2-\mathrm{H}_{\mathrm{b}}\right), 1.91$ (m, 2H, C7-H $\left./ \mathrm{C}_{\mathrm{a}}-\mathrm{H}_{\mathrm{b}} / \mathrm{C} 13-\mathrm{H}_{\mathrm{b}} \times 2\right), 1.83$ (obsc dd, $1 \mathrm{H}, J=11.8,5.2 \mathrm{~Hz}, \mathrm{C} 7-\mathrm{H}_{\mathrm{a}} / \mathrm{C} 7-\mathrm{H}_{\mathrm{b}} / \mathrm{C} 13-\mathrm{H}_{\mathrm{b}}$ ), 1.72 (obsc dd, $1 \mathrm{H}, J=15.1$, $8.3 \mathrm{~Hz}, \mathrm{C} 10-$ $\mathrm{H}_{\mathrm{a}}$ ), 1.70 (obsc m, 1H, C18-H), 1.62 (obsc td, $1 \mathrm{H}, J=9.6,7.9 \mathrm{~Hz}, \mathrm{C} 12-\mathrm{H}$ ), 1.51 (obsc dd, $1 \mathrm{H}, J$

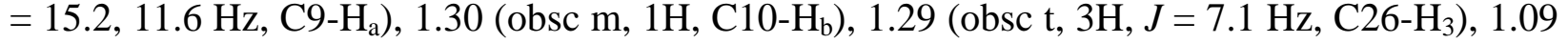
(dd, $1 \mathrm{H}, J=15.2,8.4 \mathrm{~Hz}, \mathrm{C} 9-\mathrm{H}_{\mathrm{b}}$ ), 0.96 (d, 3H, $J=6.3 \mathrm{~Hz}, \mathrm{C} 19-\mathrm{H}_{3}$ ), 0.878 (obsc d, 3H, $J=5.1$ $\mathrm{Hz}, \mathrm{C} 20-\mathrm{H}_{3}$ ), 0.873 (obsc s, 3H, C17- $\mathrm{H}_{3}$ ), 0.80 (s, 3H, C16- $\mathrm{H}_{3}$ ). (enol form, diagnostic peaks) $\delta$ 12.13 (s, 1H, C5-OH), 5.04 (s, 1H, C4-H). ESI-MS m/z (rel int): (pos) 429.2 ([M+Na] $\left.]^{+}, 100\right)$; (neg) $405.2\left([\mathrm{M}+\mathrm{Cl}]^{-}, 45\right)$. 


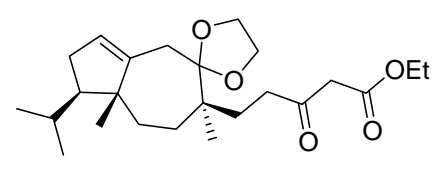

40

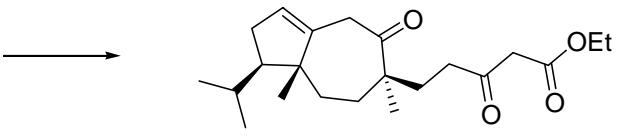

41

8 $\beta$-(4'-Carboethoxy-3'-ketobutyl)-8 $\alpha, 11 \beta$-dimethyl-12 $\beta$-isopropyl-( $\left(\Delta^{1,14}\right)$-hydroazulen-3-

one 41. In a $100 \mathrm{~mL}$ round bottom flask, the crude dioxolane 40 (943 $\mathrm{mg}, 2.32 \mathrm{mmol}, 1.0$ equiv) and $\mathrm{TsOH} \cdot \mathrm{H}_{2} \mathrm{O}$ (221 mg, $1.16 \mathrm{mmol}, 0.5$ equiv) are dissolved in $22 \mathrm{~mL}$ acetone (reagent grade), then $1.16 \mathrm{~mL} \mathrm{H}_{2} \mathrm{O}$ (5 vol\%) is added and the mixture heated to reflux under a condenser for 90 min. The acetone is evaporated and the residue is taken up in $50 \mathrm{mLEt} \mathrm{Et}_{2} \mathrm{O}$, washed $1 \times$ satd aq $\mathrm{NaHCO}_{3}, 1 \times \mathrm{H}_{2} \mathrm{O}, 1 \times$ brine, dried $\left(\mathrm{MgSO}_{4}\right)$, filtered, and evaporated to yield the crude product as a slightly yellow oil (776 mg). Purification by silica flash chromatography (9:1 hexanes/EtOAc) yields the $\beta, \zeta$-diketo ester $\mathbf{4 1}$ as a clear oil (678 $\mathrm{mg}, 80 \%$ for two steps). TLC: $R f 0.41$ (double eluted; 4:1 hexanes/EtOAc); $R f 0.62$ (1:1 hexanes/EtOAc). IR (film): 2958, $1745(\mathrm{C}=\mathrm{O}), 1714(\mathrm{C}=\mathrm{O} \times 2), 1462,1367,1317,1259,1042$. 1H$_{\mathbf{H}} \mathbf{N M R}\left(500 \mathrm{MHz}, \mathrm{CDCl}_{3}\right.$, 94:6 keto/enol form): (keto form) $\delta 5.43$ (app t, $1 \mathrm{H}, J=1.1 \mathrm{~Hz}, \mathrm{C} 14-\mathrm{H}$ ), 4.19 (q, 2H, $J=7.1 \mathrm{~Hz}$, C25- $\mathrm{H}_{2}$ ), 3.45 (obsc br d, $1 \mathrm{H}, J=11.5 \mathrm{~Hz}, \mathrm{C} 2-\mathrm{H}_{\mathrm{a}}$ ), 3.43 (obsc AB d, $1 \mathrm{H}, J=15.5 \mathrm{~Hz}, \mathrm{C} 4-\mathrm{H}_{\mathrm{a}}$ ), 3.39 (obsc AB d, $1 \mathrm{H}, J=15.5 \mathrm{~Hz}, \mathrm{C} 4-\mathrm{H}_{\mathrm{b}}$ ), 2.92 (d, 1H, $J=11.6 \mathrm{~Hz}, \mathrm{C} 2-\mathrm{H}_{\mathrm{b}}$ ), 2.54 (ddd, 1H, $J=$ 18.2, 9.9, $5.5 \mathrm{~Hz}, \mathrm{C6}-\mathrm{H}_{\mathrm{a}}$ ), 2.41 (ddd, $1 \mathrm{H}, J=18.1,9.9,5.5 \mathrm{~Hz}, \mathrm{C6}-\mathrm{H}_{\mathrm{b}}$ ), 2.29 (app ddd, $1 \mathrm{H}, J=$ 15.9, 7.7, $2.7 \mathrm{~Hz}, \mathrm{C} 13-\mathrm{H}_{\mathrm{a}}$ ), 1.94 (obsc m, 2H, C9- $\mathrm{H}_{\mathrm{a}}, \mathrm{C} 13-\mathrm{H}_{\mathrm{b}}$ ), 1.90 (obsc m, 2H, C7- $\mathrm{H}_{\mathrm{a}}, \mathrm{C} 10-$ $\mathrm{H}_{\mathrm{a}}$ ), 1.73 (app ddt, $1 \mathrm{H}, J=13.0,9.8,6.5 \mathrm{~Hz}, \mathrm{C} 18-\mathrm{H}$ ), 1.66 (ddd, $1 \mathrm{H}, J=14.4,9.8,5.5 \mathrm{~Hz}, \mathrm{C} 7-$ $\mathrm{H}_{\mathrm{b}}$ ), 1.50 (m, 2H, C9- $\left.\mathrm{H}_{\mathrm{b}}, \mathrm{C} 12-\mathrm{H}\right), 1.41$ (app dd, $\left.1 \mathrm{H}, J=14.4,11.0 \mathrm{~Hz}, \mathrm{C} 10-\mathrm{H}_{\mathrm{b}}\right), 1.28$ (t, 3H, $J=$

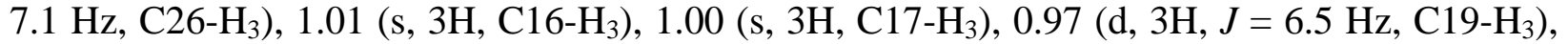
0.88 (d, 3H, $J=6.6 \mathrm{~Hz}, \mathrm{C} 20-\mathrm{H}_{3}$ ). (enol form, diagnostic peaks) $\delta 12.11$ (s, $\left.1 \mathrm{H}, \mathrm{C} 5-\mathrm{OH}\right), 4.96$ (s, 1H, C4-H). 13C-NMR (100 MHz, CDCl3): (keto form) $\delta 212.0$ (C3), 202.3 (C5), 167.1 (C15), 143.2 (C1), 126.6 (C14), 61.4 (C25), 57.9 (br, C12), 49.7 (C8), 49.4 (C4), 49.1 (C11), 42.0 (C2), 37.8 (C6), 36.3 (C10), 35.8 (C13), 32.9 (C7), 32.8 (C9), 29.5 (C18), 23.1 (C19), 22.9 (C20), 20.6 (C16), 17.2 (C17), 14.1 (C26). ESI-MS m/z (rel int): (pos) 385.1 ([M+Na $\left.]^{+}, 100\right)$; (neg) 397.0 ([M+Cl] $\left.]^{-}, 15\right), 361.1\left([\mathrm{M}-\mathrm{H}]^{-}\right.$, 45). HRMS (EI) $\mathrm{m} / \mathrm{z} 385.2350\left(\mathrm{M}+\mathrm{Na}^{+}\right)$, calcd for $\mathrm{C}_{22} \mathrm{H}_{34} \mathrm{O}_{4}$ 362.2457

Direct cyclization of $\beta, \zeta$-diketo ester 41 . In a $25 \mathrm{~mL}$ conical flask, NaOEt (21 wt\% in EtOH, $0.5 \mathrm{~mL}$ ) is diluted with $12.9 \mathrm{~mL}$ anhyd EtOH (Aldrich SureSeal) to generate a $0.1 \mathrm{~N} \mathrm{NaOEt}$ solution. This stock solution ( $364 \mu \mathrm{L}, 36.4 \mu \mathrm{mol}, 1.2$ equiv) is added to the neat $\beta, \zeta$-diketo ester 41 (11 mg, $30.3 \mu \mathrm{mol}, 1.0$ equiv) under air in a $4 \mathrm{~mL}$ wheaton vial. The vial is closed with a teflon-faced cap and the yellow solution is heated to $60^{\circ} \mathrm{C}$. After $19 \mathrm{~h}$, the cloudy orange mixture is diluted with $1 \mathrm{~N}$ aq $\mathrm{HCl}$ and extracted $3 \times$ EtOAc. The combined organic extracts are washed $1 \times \mathrm{H}_{2} \mathrm{O}, 1 \times$ brine, dried $\left(\mathrm{MgSO}_{4}\right)$, filtered, and evaporated to yield the crude product as a yellow oil (11 mg). NMR analysis indicated a 62:30:8 mixture of 44, 46, and 45 based on integration of the vinylic $\mathrm{C} 14-\mathrm{H}$ peaks. Purification by silica flash chromatography yielded the "truncated" ester $\mathbf{4 4}$ as a clear residue (6 mg), and the tricyclic alcohol $\mathbf{4 6}$ as a clear oil (3.5 $\mathrm{mg}$ ). The tricyclic diketone was isolated from a separate run as a clear residue $(0.6 \mathrm{mg})$. 


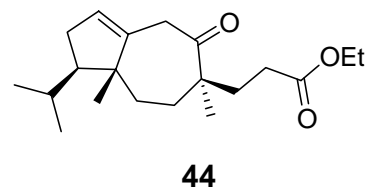

8 $\beta$-(2'-(Carboethoxy)ethyl)-8 $\alpha, 11 \beta$-dimethyl-12 $\beta$-isopropyl-( $\left.\Delta^{1,14}\right)$-hydroazulen-3-one 44. Structure Determination: Inspection of the NMR spectrum revealed that the compound was very similar to $\mathbf{4 1}$ but lacked the diagnostic $\beta$-keto ester $\alpha$-protons $\left(\mathrm{C} 4-\mathrm{H}_{2}\right)$. The "truncated" ester structure $\mathbf{4 4}$ was confirmed by MS analysis. TLC: $R f 0.67$ (1:1 hexanes/EtOAc). ${ }^{\mathbf{1}}$ H-NMR (500 $\mathrm{MHz}, \mathrm{CDCl}_{3}$ ): $\delta 5.43$ (app s, 1H), 4.11 (q, $1 \mathrm{H}, J=7.1 \mathrm{~Hz}$ ), 3.46 (br d, $1 \mathrm{H}, J=11.6 \mathrm{~Hz}$ ), 2.94 (d, $1 \mathrm{H}, J=11.6 \mathrm{~Hz}$ ), 2.33-2.25 (m, 2H), 2.20-2.12 (m, 2H), 1.98-1.85 (m, 4H), 1.76-1.69 (m, 2H), 1.51 (obsc m, 1H), 1.42 (app dd, $1 \mathrm{H}, J=15.2,10.9 \mathrm{~Hz}$ ), 1.25 (t, 3H, $J=7.1 \mathrm{~Hz}$ ), 1.03 (s, 3H), 1.00 (s, 3H), 0.97 (d, 3H, $J=6.5 \mathrm{~Hz}$ ), 0.88 (d, 3H, $J=6.6 \mathrm{~Hz}$ ). ESI-MS $\mathrm{m} / \mathrm{z}$ (rel int): (pos) $343.0\left([\mathrm{M}+\mathrm{Na}]^{+}, 100\right)$.

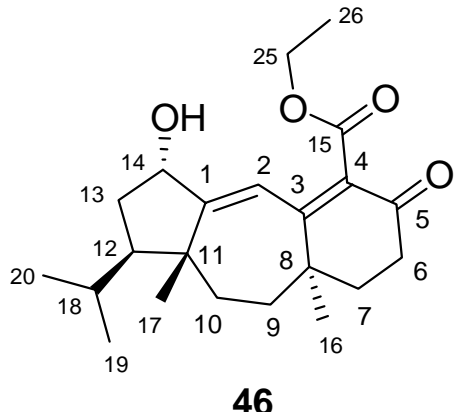

46. Structure Determination: Inspection of the NMR spectrum at $24{ }^{\circ} \mathrm{C}$ revealed several indications of cyclization. Most strikingly, many peaks in the aliphatic methylene region (2.6$1.4 \mathrm{ppm}$ ) were broad, consistent with the conformational isomerism reported for guanacastepene A at rt. Furthermore, the diastereotopic ethyl ester methylene protons $\left(\mathrm{C} 25-\mathrm{H}_{2}\right)$, which had exhibited as a single quartet in $\mathbf{4 1}$, now presented as two separate doublets of quartets. The downfield shift of the single vinylic proton from $5.43 \mathrm{ppm}$ in $\mathbf{4 1}$ to $6.17 \mathrm{ppm}$ in $\mathbf{4 6}$, together with the absence of the $\mathrm{C} 2-\mathrm{H}_{2} \mathrm{AB}$ quartet of $\mathbf{4 1}$ in the $3.5-2.9 \mathrm{ppm}$ region, supported reconjugation of the double bond with the carbonyl system. Finally, a broad singlet at $4.44 \mathrm{ppm}$ was indicative of a $\mathrm{R}_{2} \mathrm{CH}-\mathrm{OH}$ group. Presence of a hydroxyl group was confirmed by a broad $\mathrm{O}-\mathrm{H}$ stretching band in the IR spectrum at $3441 \mathrm{~cm}^{-1}$. We first considered that reduction of the C5 ketone may have occurred, however, the IR spectrum showed two carbonyl $\mathrm{C}=\mathrm{O}$ stretching bands at 1732 and $1667 \mathrm{~cm}^{-1}$ and MS analysis indicated a molecular weight 16 amu higher than expected for 42. Thus, we proposed the oxidized structure $\mathbf{4 6}$ that was ultimately confirmed by multidimensional NMR analysis at $50{ }^{\circ} \mathrm{C}$. TLC: $R f 0.25$ ( $1: 1$ hexanes/EtOAc). IR (film): 3441 (br, O-H), 2958, 2932, 2870, 1732 (ester C=O), 1667 (ketone C=O), 1452, 1368, 1297, 1227, 1177, 1021. 1H-NMR (500 MHz, CDCl 3$):\left(50^{\circ} \mathrm{C}\right) \delta 6.17$ (d, $\left.1 \mathrm{H}, J=1.3 \mathrm{~Hz}, \mathrm{C} 2-\mathrm{H}\right), 4.43$ (br d, $1 \mathrm{H}, J=6.5 \mathrm{~Hz}, \mathrm{C} 14-\mathrm{H}), 4.28$ (dq, $1 \mathrm{H}, J=10.8,7.1 \mathrm{~Hz}, \mathrm{C} 25-\mathrm{H}_{\mathrm{a}}$ ), 4.21 (dq, $1 \mathrm{H}, J=10.8,7.1 \mathrm{~Hz}$, C25- $\mathrm{H}_{\mathrm{b}}$ ), 2.52 (app dd, $2 \mathrm{H}, J=7.6,6.2 \mathrm{~Hz}, \mathrm{C} 6-\mathrm{H}_{2}$ ), 2.01 (obsc m, 1H, C7- $\mathrm{H}_{\mathrm{a}}$ ), 1.97 (obsc m, 2H, C9- $\mathrm{H}_{\mathrm{a}}, \mathrm{C} 10-\mathrm{H}_{\mathrm{a}}$ ), 1.88-1.77 (obsc m, 4H, C13- $\mathrm{H}_{\mathrm{a}}, \mathrm{C} 12-\mathrm{H}, \mathrm{C} 7-\mathrm{H}_{\mathrm{b}}, \mathrm{C} 10-\mathrm{H}_{\mathrm{b}}$ ), 1.73 (obsc m, $1 \mathrm{H}$, C13- $\mathrm{H}_{\mathrm{b}}$ ), 1.65 (obsc app oct, $1 \mathrm{H}, J=6.7 \mathrm{~Hz}, \mathrm{C} 18-\mathrm{H}$ ), 1.56 (dd, $1 \mathrm{H}, J=12.4,7.4 \mathrm{~Hz}, \mathrm{C}-\mathrm{H}_{\mathrm{b}}$ ), 1.26 (t, 3H, $\left.J=7.1 \mathrm{~Hz}, \mathrm{C} 26-\mathrm{H}_{3}\right), 1.24$ (s, 3H, C16- $\mathrm{H}_{3}$ ), 0.99 (d, 3H, $\left.J=6.7 \mathrm{~Hz}, \mathrm{C} 19 / 20-\mathrm{H}_{3}\right), 0.95$ (s, 3H, C17- $\left.\mathrm{H}_{3}\right), 0.92$ (d, 3H, $\left.J=6.7 \mathrm{~Hz}, \mathrm{C} 20 / 19-\mathrm{H}_{3}\right) .{ }^{13} \mathrm{C}-\mathbf{N M R}\left(100 \mathrm{MHz}, \mathrm{CDCl}_{3}\right):\left(\mathbf{5 0}^{\circ} \mathbf{C}\right) \delta$ 194.3 (C5), 166.5 (C15), 164.1 (C1), 162.0 (C3), 133.3 (C4), 119.3 (C2), 73.6 (C14), 60.9 (C25), 
53.2 (br, C12), 48.5 (C11), 38.3 (br, C8), 36.8 (br, C7), 36.7 (C13), 36.4 (C9), 33.8 (C6), 33.5 (br, C10), 28.1 (C18), 25.2 (C16), 23.9 (C19/20), 22.0 (C20/19), 20.5 (br, C17), 14.2 (C26). ESI-MS m/z (rel int): (pos) $383.2\left([\mathrm{M}+\mathrm{Na}]^{+}, 100\right)$; (neg) 394.9 ([M+Cl] $]^{-}$, 55), $359.1\left([\mathrm{M}-\mathrm{H}]^{-}\right.$, 40). HR-FAB-MS $\mathrm{m} / \mathrm{z}$ calcd for $\mathrm{C}_{22} \mathrm{H}_{32} \mathrm{O}_{4} \mathrm{Na} 383.2198$; found 383.2198.

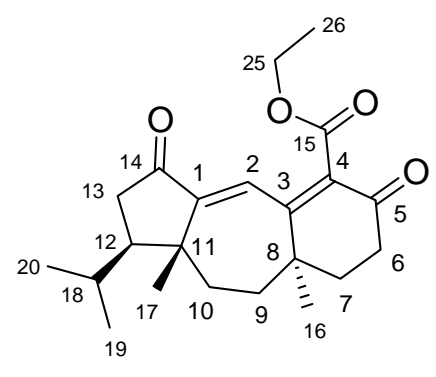

45

4-Carboethoxy-8 $\alpha, 11 \beta$-dimethyl-12 $\beta$-isopropyl-14-keto- $\left(\Delta^{1,2}, \Delta^{3,4}\right)$-tricycle $45 . \quad$ Structure Determination: Inspection of the NMR spectrum again indicated cyclization with broad peaks in the aliphatic methylene region (2.6-1.4 ppm) and a complex multiplet corresponding to the ethyl ester methylene $\left(\mathrm{C} 25-\mathrm{H}_{2}\right)$. We noted a further significant downfield shift of the vinylic proton from $6.17 \mathrm{ppm}$ in $\mathbf{4 6}$ to 6.87 in $\mathbf{4 5}$, absence of the $\mathrm{R}_{2} \mathrm{CH}-\mathrm{OH}$ signal around 4.5-4.4 ppm, and the downfield shift of two protons from the 2.1-1.4 ppm range in $\mathbf{4 6}$ to 2.2 and $2.5 \mathrm{ppm}$ in $\mathbf{4 5}$. MS analysis indicated a molecular weight 14 amu higher than that expected for $\mathbf{4 2}$. This led us to propose the diketo ester structure 45, which was confirmed by multidimensional NMR analysis at $24{ }^{\circ} \mathrm{C}$. TLC: $R f 0.48$ (1:1 hexanes/EtOAc). ${ }^{1} \mathbf{H}-\mathbf{N M R}\left(500 \mathrm{MHz}, \mathrm{CDCl}_{3}\right.$, partially assigned based on COSY and NOESY; C7- $\mathrm{H}_{2}, \mathrm{C} 9-\mathrm{H}_{2}, \mathrm{C} 10-\mathrm{H}_{\beta}$ not assigned): $\left(24^{\circ} \mathrm{C}\right) \delta 6.87(\mathrm{~s}, 1 \mathrm{H}, \mathrm{C} 2-$ H), 4.28 (m, 2H, C25- $\mathrm{H}_{2}$ ), 2.57 (obsc m, 2H, C6- $\mathrm{H}_{2}$ ), 2.53 (obsc dd, $1 \mathrm{H}, J=18.5,7.7 \mathrm{~Hz}, \mathrm{C} 13-$ $\mathrm{H}_{\alpha}$ ), 2.18 (dd, $1 \mathrm{H}, J=18.6,12.9 \mathrm{~Hz}, \mathrm{C} 13-\mathrm{H}_{\beta}$ ), 2.14-1.95 (br s, $2 \mathrm{H}$ ), 2.01 (br dd, $1 \mathrm{H}, J=12.8$, $11.9 \mathrm{~Hz}, \mathrm{C} 10-\mathrm{H}_{\alpha}$ ), 1.95-1.75 (br s, 2H), 1.80 (app sxt, $\left.1 \mathrm{H}, J=6.8 \mathrm{~Hz}, \mathrm{C} 18-\mathrm{H}\right), 1.69$ (m, $1 \mathrm{H}$, C12-H), 1.60 (obsc m, 1H), 1.27 (t, 3H, $J=7.1 \mathrm{~Hz}, \mathrm{C} 26-\mathrm{H}_{3}$ ), 1.22 (s, 3H, C16-H , $_{3}, 1.09$ (s, 3H, C17- $\left.\mathrm{H}_{3}\right), 1.06$ (d, 3H, $\left.J=6.6 \mathrm{~Hz}, \mathrm{C} 19-\mathrm{H}_{3}\right), 0.95$ (d, 3H, $\left.J=6.6 \mathrm{~Hz}, \mathrm{C} 20-\mathrm{H}_{3}\right)$. ESI-MS $\mathrm{m} / z(\mathrm{rel}$ int): (pos) 381.1 ([M+Na $\left.]^{+}, 100\right)$; (neg) 392.9 ([M+Cl] $\left.]^{-}, 60\right), 357.0$ ([M-H] $\left.]^{-}, 65\right)$.

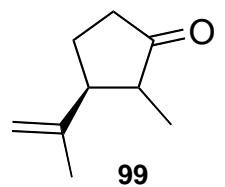

ketone 99: Under argon atmosphere, cuprous thiocynate ( $2.76 \mathrm{~g}, 22.5 \mathrm{mmol})$, powdered $4 \AA$ molecular sieves (3g), and anhydrous diethyl ether (375 ml) were placed in a 500-ml septumsealed flask equipped with a magnetic stirring bar, and cooled to $-45^{\circ} \mathrm{C}$. First $29.4 \mathrm{ml}(42 \mathrm{mmol})$ of isopropenyllithium in n-hexane was added by syringe, and the mixture was stirred for $1 \mathrm{~h}$ and allowed to warm up to $-25^{\circ} \mathrm{C}$. Then the mixture was cooled to $-60{ }^{\circ} \mathrm{C}$ and (S)-2(methoxymethyl)pyrrolidine (5.67 ml, $45 \mathrm{mmol}$ ) in $45 \mathrm{ml}$ of anhydrous ether was added by syringe. Stirring was continued for $30 \mathrm{~min}$ while the temperature went up to $-50^{\circ} \mathrm{C}$. Finally ketone $4(735 \mu \mathrm{l}, 7.5 \mathrm{mmol})$ within 5 min was added by syringe at $-100^{\circ} \mathrm{C}$ and the resulting mixture after stirring for $30 \mathrm{~min}$ at that temperature was poured into $80 \mathrm{ml}$ of ice water saturated with ammonium chloride, and $100 \mathrm{ml}$ of ether. After stirring for $15 \mathrm{~min}$ the mixture was filtered through Celite. The aqueous layer was separated and washed with $100 \mathrm{ml}$ of ether. The 
combined organic layers were washed successively with $50 \mathrm{ml}$ each of $2 \mathrm{~N} \mathrm{HCl}$, saturated aqueous solutions of sodium hydrogencarbonate and sodium chloride. After drying over magnesium sulfate, the solvent was removed and the reaction mixture was purified by column chromatography to afford ketone 99 was isolated (995 mg, $96 \%$ ). Physical properties were identical to those of previous report (Quinkert, G.; Müller, T.; Königer, A.; Schultheis, O.; Sickenberger, B.; Dürner, G. Tetrahedron Lett. 1992, 33, 3469). HPLC analysis showed this product had an ee of $90 \%$. (chiralpak ${ }^{\circledR} \mathrm{AD}, 99.8 \%$ hexane:0.2\% isopropyl alcohol).

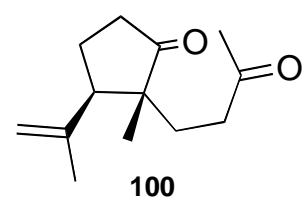

diketone 100: Under argon atmosphere, into a flask were introduced the silyl enol ether of $\mathbf{9 9}$ (0.599 g, $2.373 \mathrm{mmol})$ in dichloromethane at room temperature, then at $-20^{\circ} \mathrm{C}$, a solution of methyl vinyl ketone $(0.162 \mathrm{ml}, 1.977 \mathrm{mmol})$ in dichloromethane, a solution of boron-trifluoridediethyl ether ( $25 \mu \mathrm{l}, 0.1977 \mathrm{mmol})$ and acetic acid $(0.112 \mathrm{ml}, 1.997 \mathrm{mmol})$. The mixture was stirred at $-20^{\circ} \mathrm{C}$ for $1 \mathrm{hr}$, then allowed to warm to room temperature and saturated aq. $\mathrm{NaHCO}_{3}$ was added. After extraction with dichloromethane, filtered and evaporated, the reaction mixture was purified by column chromatography to afford the diketone $100(0.3675 \mathrm{~g}, 90 \%)$. IR (thin film) 1720, $1735 \mathrm{~cm}^{-1}$; ${ }^{1} \mathbf{H}$ NMR $\left(400 \mathrm{MHz}, \mathrm{CDCl}_{3}\right) \delta 4.94(\mathrm{t}, 1 \mathrm{H}, J=1.5 \mathrm{~Hz}), 4.76(\mathrm{~s}, 1 \mathrm{H})$, 2.65-2.57 (m, 1H), 2.57-2.49 (m, 1H), 2.44-2.37 (m, 1H), 2.37-2.28 (m, 1H), 2.25-2.16 (m, 1H), 2.14 (s, 3H), 2.08-2.00 (m, 1H), 1.96-1.84 (m, 2H), 1.82-1.74 (m, 1H), 1.76 (s, 3H), 0.84 (s, 3H); ${ }^{13}$ C NMR $\left(100 \mathrm{MHz}, \mathrm{CDCl}_{3}\right) \delta 222.14,208.16,143.90,113.31,50.87,50.27,38.62$, 37.12, 30.38, 29.97, 23.27, 23.19, 18.06; LRMS Calcd for $\mathrm{C}_{13} \mathrm{H}_{20} \mathrm{O}_{2}$ : 208.30. Found: 209.23.

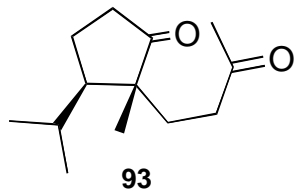

diketone 93: To a benzene solution of 100 (70.5 mg, $0.3384 \mathrm{mmol}$ )was added Pd/C (5 mg) and the reaction mixture was stirred under hydrogen atmosphere. After 2 days, reaction mixture was filtered through a Celite and solvent was removed. The resulting reaction mixture was purified by column chromatography to afford the diketone 93 (65.2 $\mathrm{mg}, 92 \%)$. Identification as cis isomer was done as follows: irradiating the 2-methyl gave no nOe effect on $3-\mathrm{H}$ but gave a strong nOe effect on the hydrogen of the isopropyl group. $[\alpha]_{\mathbf{D}}{ }^{24.4}+5.84\left(c 0.23, \mathrm{CHCl}_{3}\right)$; IR (thin film) 1720, $1740 \mathrm{~cm}^{-1}$; ${ }^{1} \mathbf{H}$ NMR (400 MHz, $\left.\mathrm{CDCl}_{3}\right) \delta 2.50-2.41(\mathrm{~m}, 1 \mathrm{H}), 2.36-2.28(\mathrm{~m}$, $1 \mathrm{H}), 2.26-2.17$ (m, 1H), 2.11 (s, 3H), 2.10-2.02 (m, 2H), 1.98-1.91 (m, 1H), 1.80-1.72 (m, $1 \mathrm{H})$, 1.72-1.62 (m, 2H), 1.55-1.40 (m, 1H), 0.99 (d, 3H, $J=6.2 \mathrm{~Hz}), 0.95-0.90$ (m, 6H); ${ }^{13} \mathbf{C}$ NMR $\left(100 \mathrm{MHz}, \mathrm{CDCl}_{3}\right) \delta 223.8,208.6,51.2,49.7,39.1,37.5,31.4,30.0,29.4,23.5,22.5,21.3,17.8$; LRMS Calcd for $\mathrm{C}_{14} \mathrm{H}_{22} \mathrm{O}_{2}$ : 210.31. Found: 210.16. 


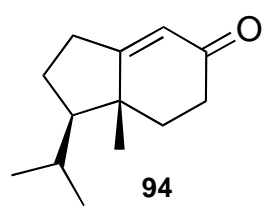

enone 94: To a diketone 93 (0.296 g, $1.407 \mathrm{mmol})$ was added a methanolic solution (0.5 M) of sodium methoxide $(2 \mathrm{ml})$. After refluxing overnight, saturated aq. $\mathrm{NaCl}$ was added. The mixture was extracted with diethyl ether, the combined organic layers were washed with brine, and then the solvent was evaporated. The reaction mixture was purified by column chromatography to afford $94(0.265 \text { g, 98\%). [ } \alpha]_{\mathbf{D}}{ }^{22.6}+62.9\left(c 1.0, \mathrm{CDCl}_{3}\right) ;{ }^{1} \mathbf{H}$ NMR $\left(400 \mathrm{MHz}, \mathrm{CDCl}_{3}\right) \delta 5.74(\mathrm{~s}$, $1 \mathrm{H}), 2.68-2.56(\mathrm{~m}, 1 \mathrm{H}), 2.56-2.47(\mathrm{~m}, 1 \mathrm{H}), 2.47-2.38(\mathrm{~m}, 1 \mathrm{H}), 2.38-2.27(\mathrm{~m}, 1 \mathrm{H}), 2.27-2.20$ (m, 1H), 2.05-1.96 (m, 1H), 1.89-1.79 (m, 1H), 1.73-1.64 (m, 1H), 1.62-1.48 (m, $1 \mathrm{H})$, 1.35-1.25 (m, 1H), 1.04 (s, 3H), 1.00 (d, 3H, $J=6.6 \mathrm{~Hz}), 0.95$ (d, 3H, $J=6.6 \mathrm{~Hz}) ;{ }^{13} \mathbf{C}$ NMR $\left(100 \mathrm{MHz}, \mathrm{CDCl}_{3}\right) \delta 199.67,180.53,121.20,58.03,45.4,37.5,34.0,30.3,29.4,27.5,23.4,23.0$, 16.8; HRMS Calcd for $\mathrm{C}_{13} \mathrm{H}_{20} \mathrm{O}$ : 192.30. Found: 192.1516.

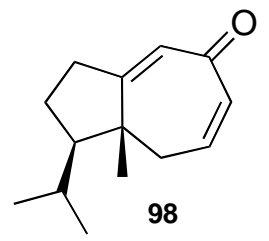

dienone 98: To a solution of $\left({ }^{i} \mathrm{Pr}\right)_{2} \mathrm{NH}(0.53 \mathrm{ml}, 3.786 \mathrm{mmol})$ in THF was added $n$-BuLi $(1.6 \mathrm{M}$ Hexane, $2.11 \mathrm{ml}, 3.380 \mathrm{mmol})$ at $-78{ }^{\circ} \mathrm{C}$. After $30 \mathrm{~min}$ at $0{ }^{\circ} \mathrm{C}$, the reaction mixture was cooled to $-78{ }^{\circ} \mathrm{C}$ and a THF solution of $94(0.26 \mathrm{~g}, 1.352 \mathrm{mmol})$ was added with stirring. After $30 \mathrm{~min}$, TMSCl (1 M THF, $2.7 \mathrm{ml}, 2.70 \mathrm{mmol}$ ) was added, the cold mixture was stirred for $30 \mathrm{~min}$, then warmed to room temperature and submitted to an aqueous workup. After evaporation in vacuo, the crude diene 95 was diluted with diethyl ether and cooled to $0{ }^{\circ} \mathrm{C}$. Diethyl zinc $(1.9 \mathrm{ml} ., 1.864$ mmol) and diiodomethane $(0.11 \mathrm{ml}, 1.367 \mathrm{mmol})$ were successively added and the reaction mixture was warmed to room temperature. After being stirred overnight, the reaction mixture was cooled in an ice-water bath and quenched with ammonium chloride. After separation, the ether layer was filtered through a short pad of silica gel, which was washed with 20:1 (v:v) etherpentane. The combined filtrates were washed with ammonium chloride and brine. After evaporation in vacuo, the crude trimethylsilyloxycyclopropane $\mathbf{9 6}$ was diluted with DMF. To this was added, via syringe pump during $2 \mathrm{hr}$, a solution of $\mathrm{FeCl}_{3}$ in DMF, previously prepared by slowly adding anhydrous $\mathrm{FeCl}_{3}(0.548 \mathrm{mg}, 3.380 \mathrm{mmol})$, with stirring, to DMF precooled at 0 ${ }^{\circ} \mathrm{C}$. After the addition was complete, the resulting brown solution was stirred at room temperature for 2 more hours, then quenched with ice-cold $1 \mathrm{~N} \mathrm{HCl}$. After aqueous workup and evaporation in vacuo, the crude chlorocycloheptenone $\mathbf{9 7}$ was dissolved in methanol saturated with $\mathrm{NaOAc}(5 \mathrm{ml})$ and heated at reflux for overnight. The reaction mixture was cooled to room temperature and submitted to aqueous workup. After evaporation of organic solvent, the crude 
product was purified by column chromatography to afford $98(110.5 \mathrm{mg}, 40 \%)$. $[\alpha]_{\mathbf{D}}{ }^{22.7}-65.6(\mathrm{C}$ 0.35, $\left.\mathrm{CHCl}_{3}\right) ;{ }^{1} \mathbf{H}$ NMR (400 MHz, $\left.\mathrm{CDCl}_{3}\right) \delta 6.42(\mathrm{~m}, 1 \mathrm{H}), 6.13(\mathrm{~m}, 1 \mathrm{H}), 5.97(\mathrm{~d}, 1 \mathrm{H}, J=1.9$ $\mathrm{Hz}), 2.72$ (m, 1H), 2.64-2.45 (m, 3H), 1.96-1.86 (m, 1H), 1.75-1.67 (m, 1H), 1.56-1.47 (m, 2H), 1.09 (s, 3H), 1.03 (d, 3H, $J=6.7 \mathrm{~Hz}), 0.95$ (d, 3H, $J=6.7 \mathrm{~Hz}) ;{ }^{13} \mathrm{C}$ NMR $(100 \mathrm{MHz}$, $\left.\mathrm{CDCl}_{3}\right) \delta 191.13,173.20,140.83,133.61,124.78,58.32,48.32,39.07,32.92,28.15,26.61$, 24.10, 22.42, 17.74; HRMS Calcd for $\mathrm{C}_{14} \mathrm{H}_{20} \mathrm{O}$ : 204.31. Found: 205.159. 

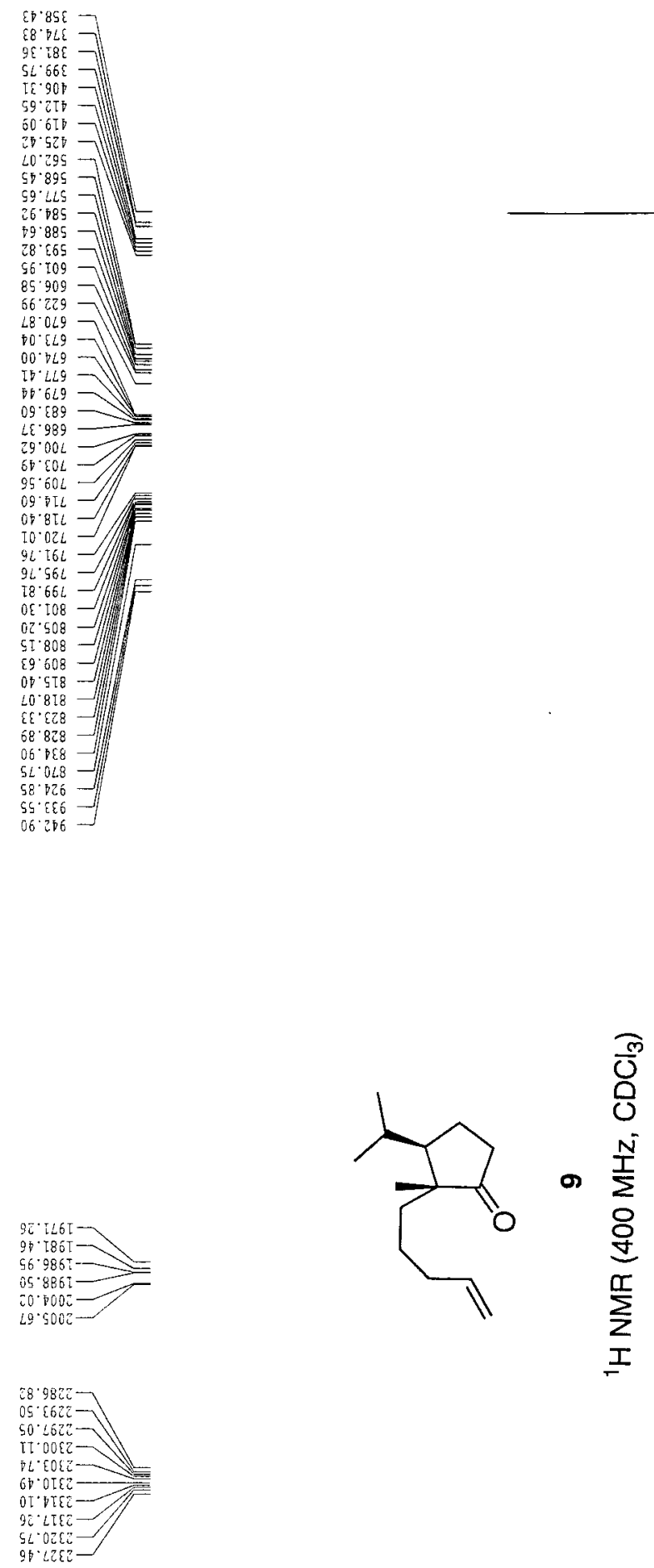

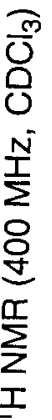
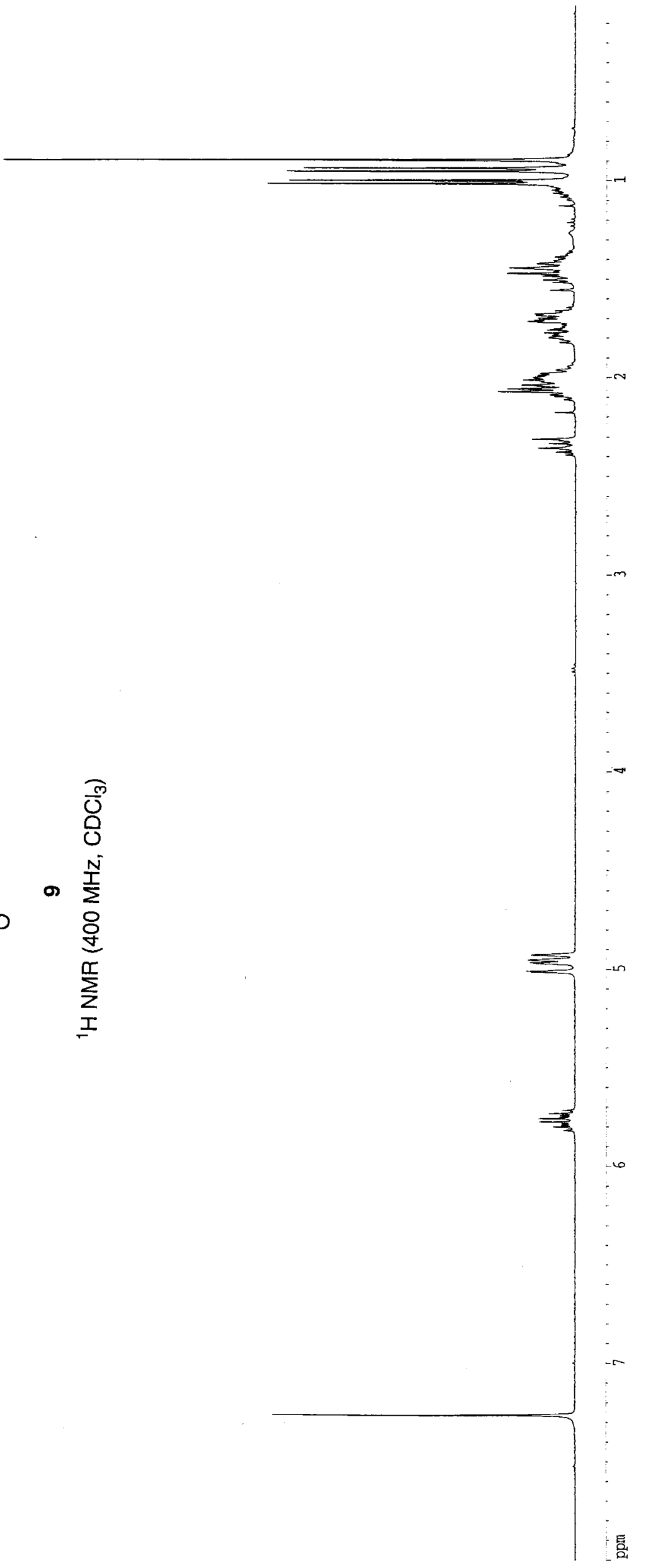


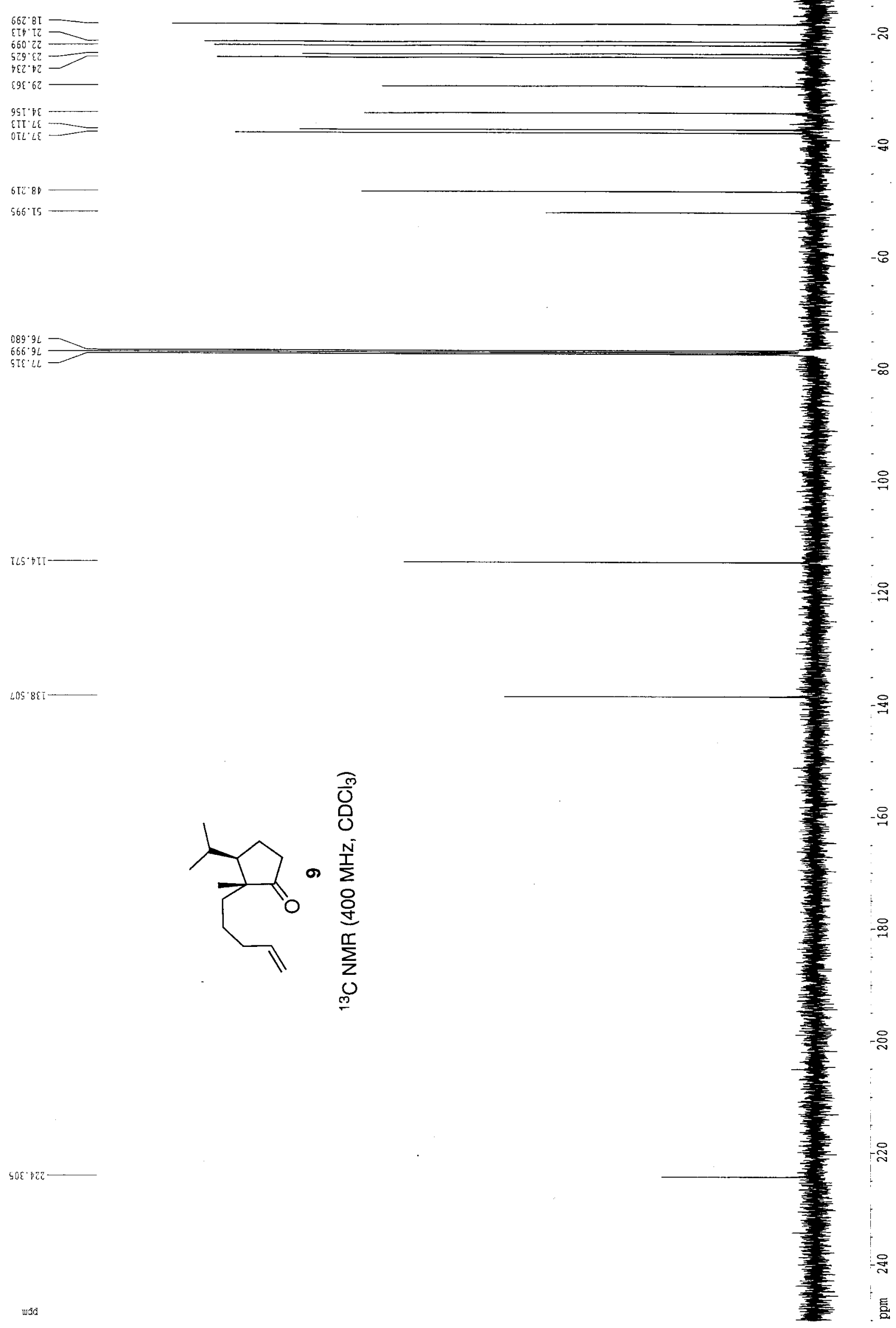




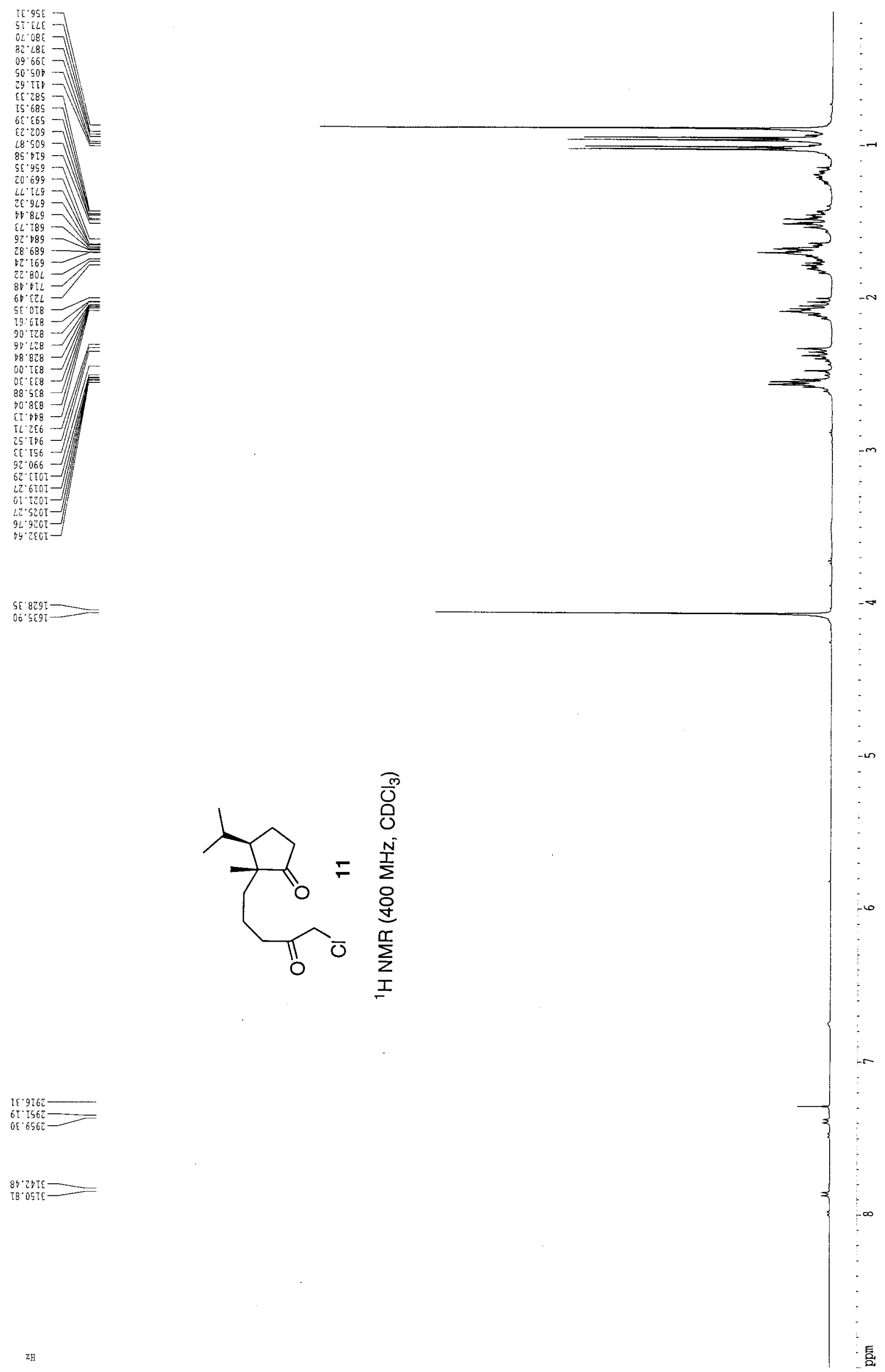




$$
1
$$



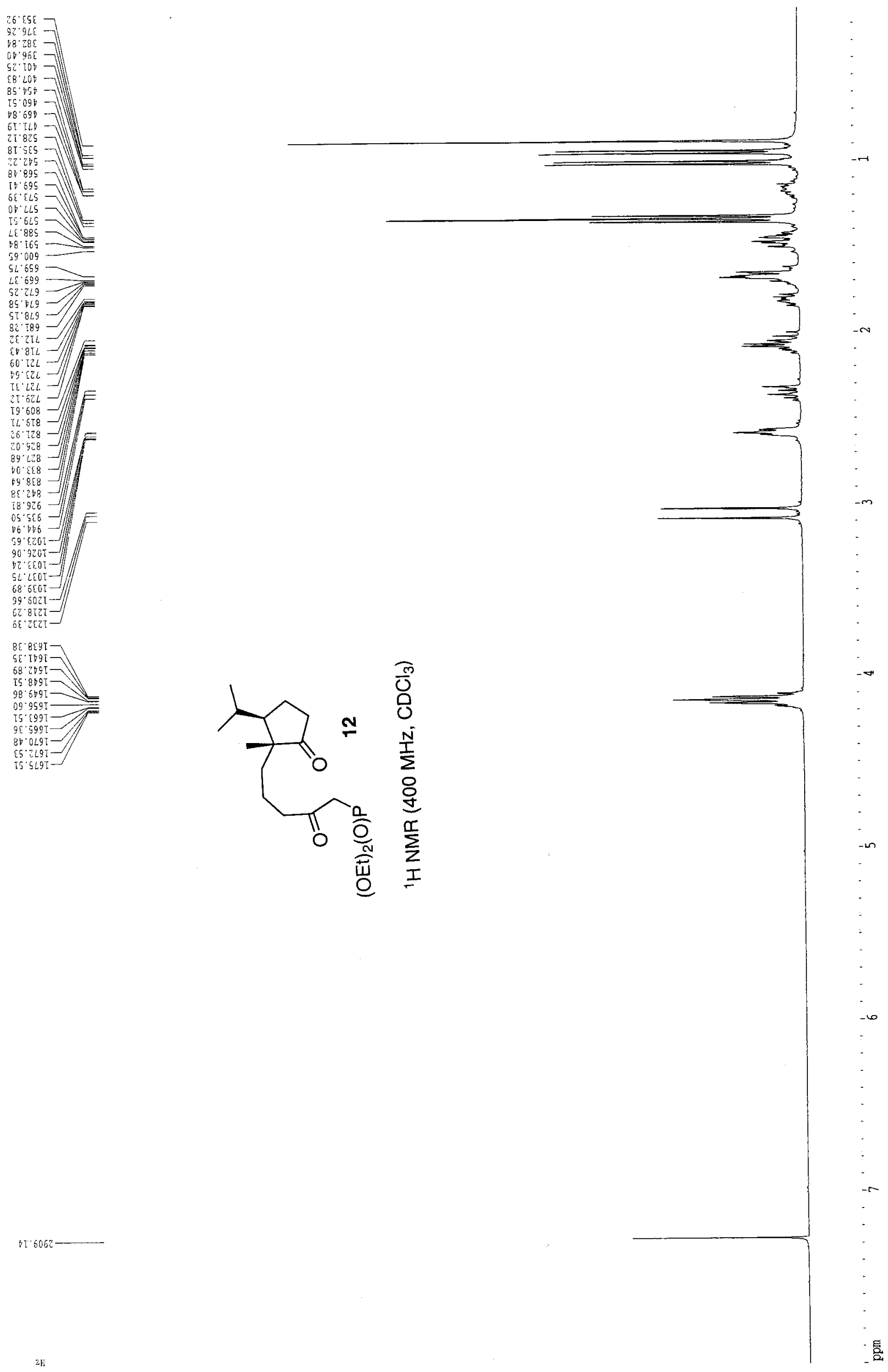


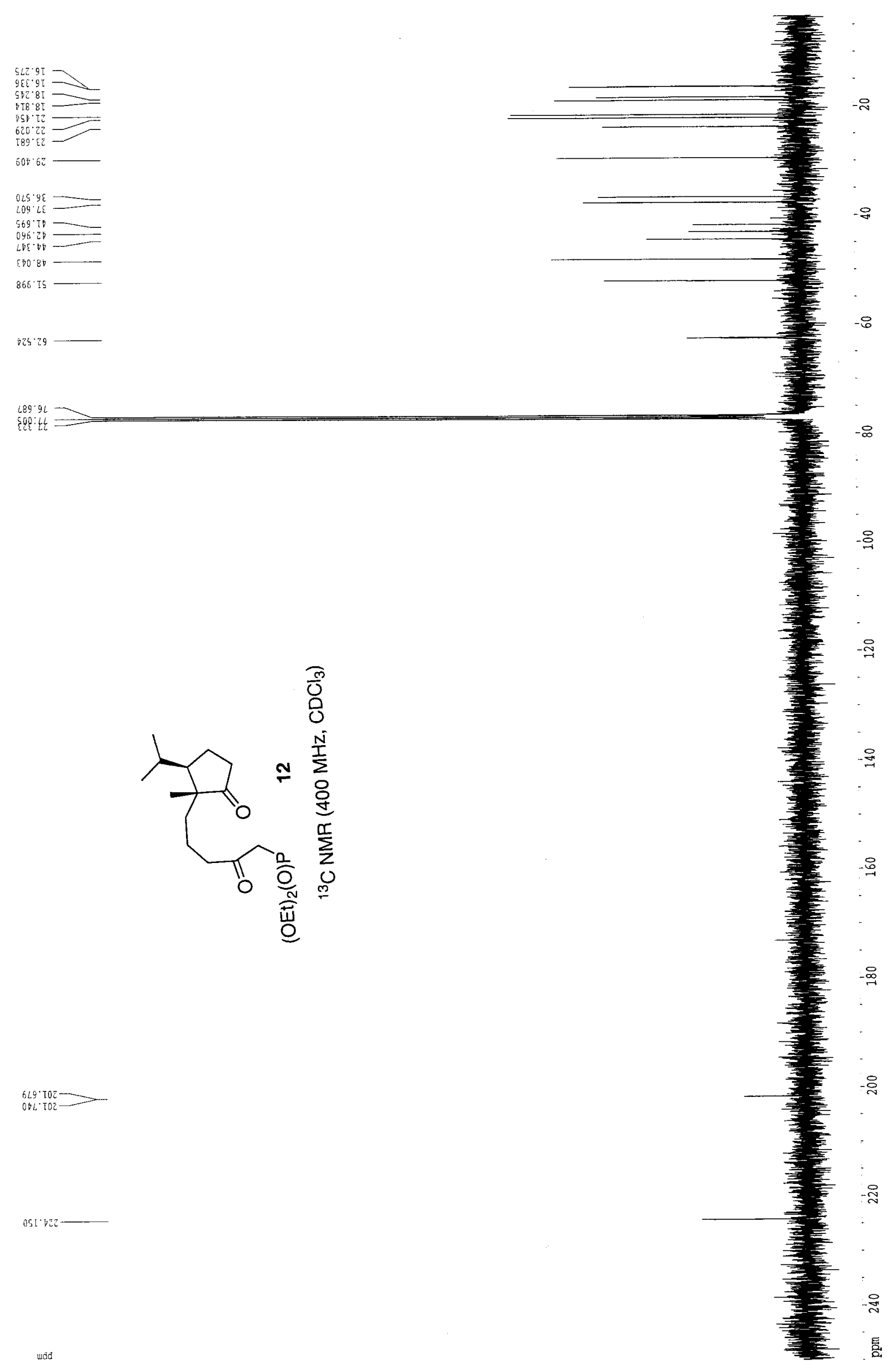




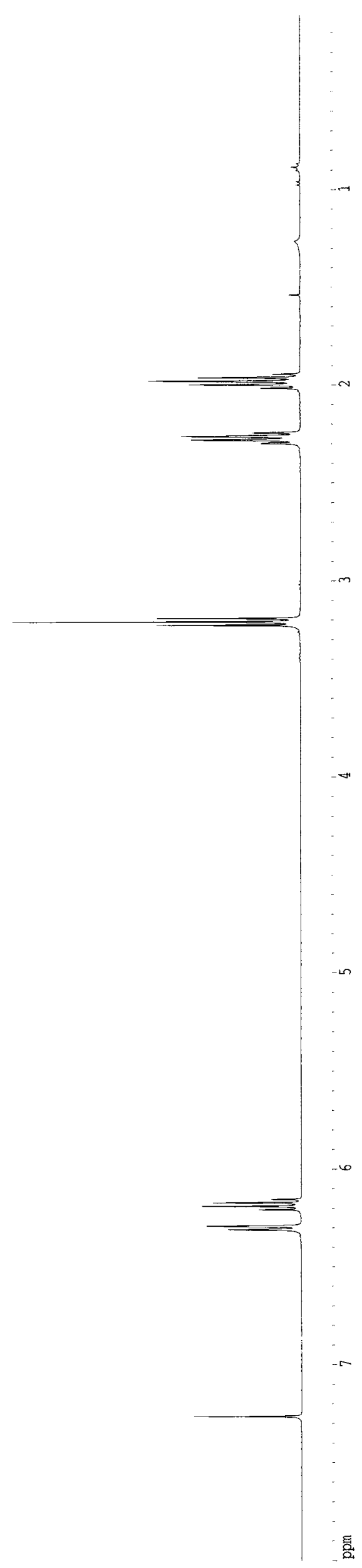

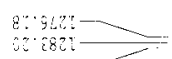

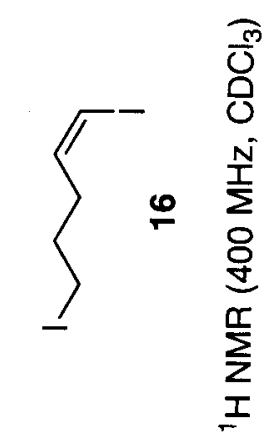

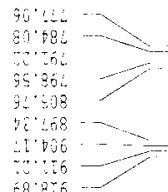




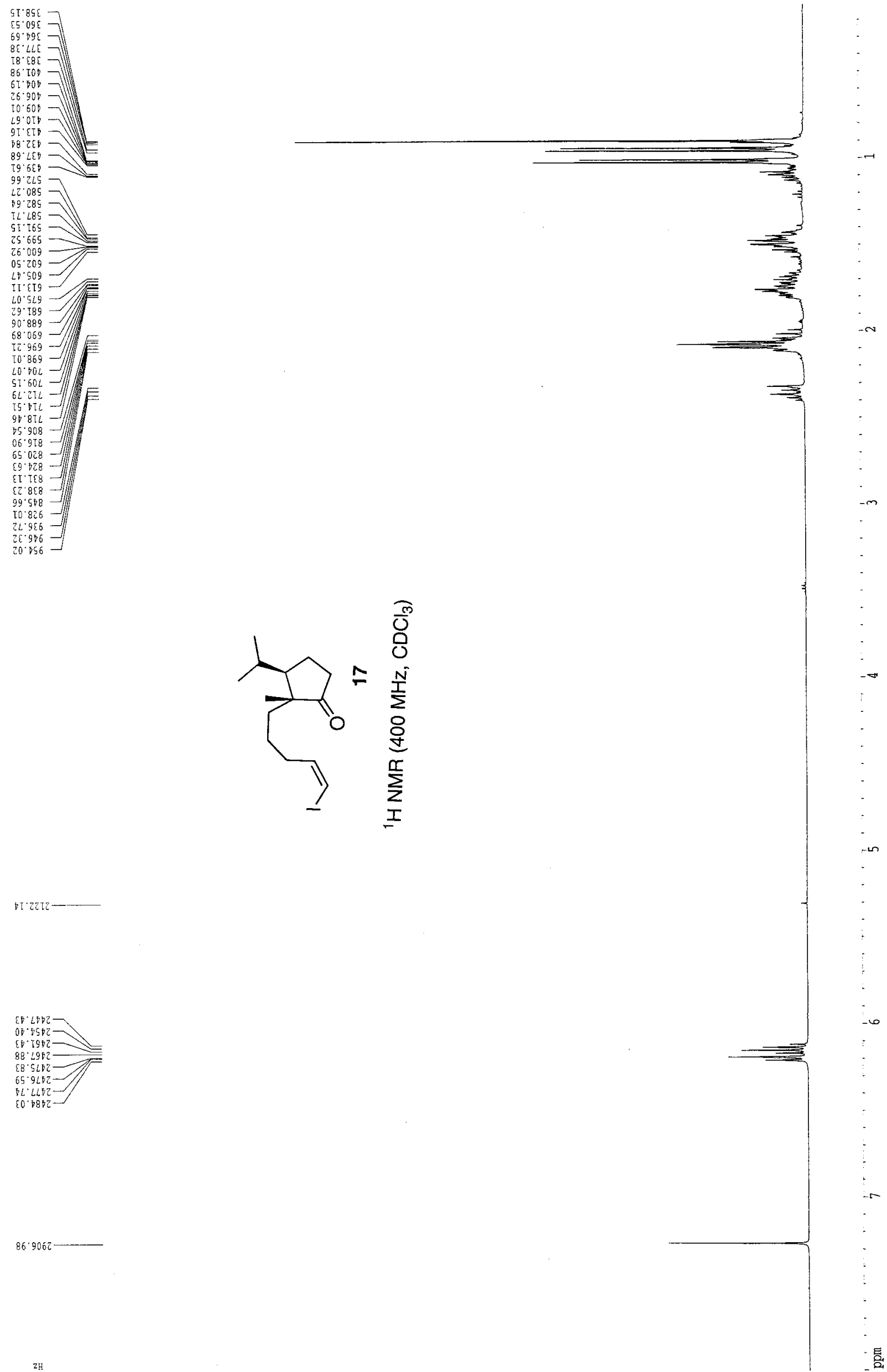

言 

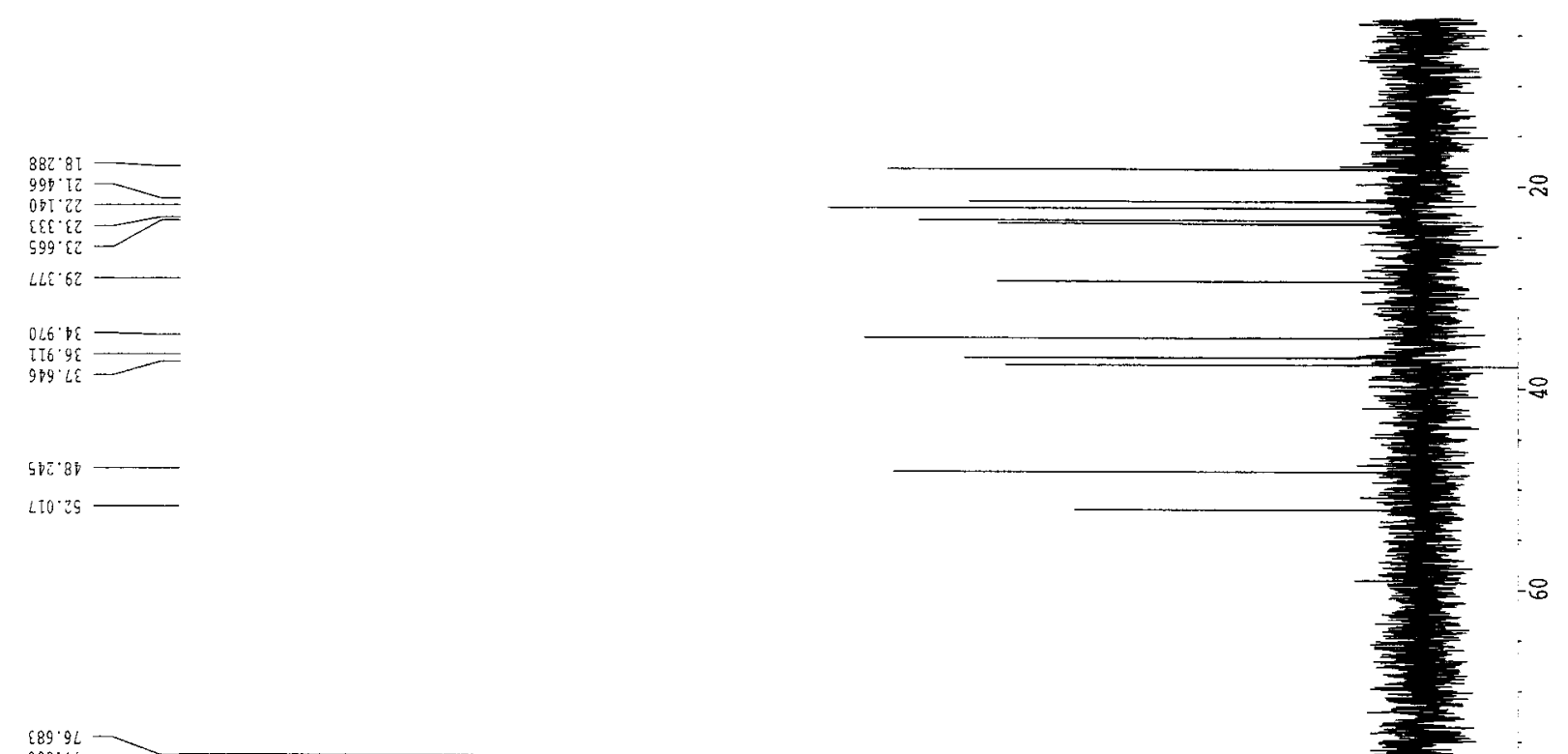

$289.9 L$
$000{ }^{\circ} L L$
$2 I C^{\circ} L L$

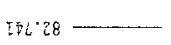

$8: 8 \cdot 061-$
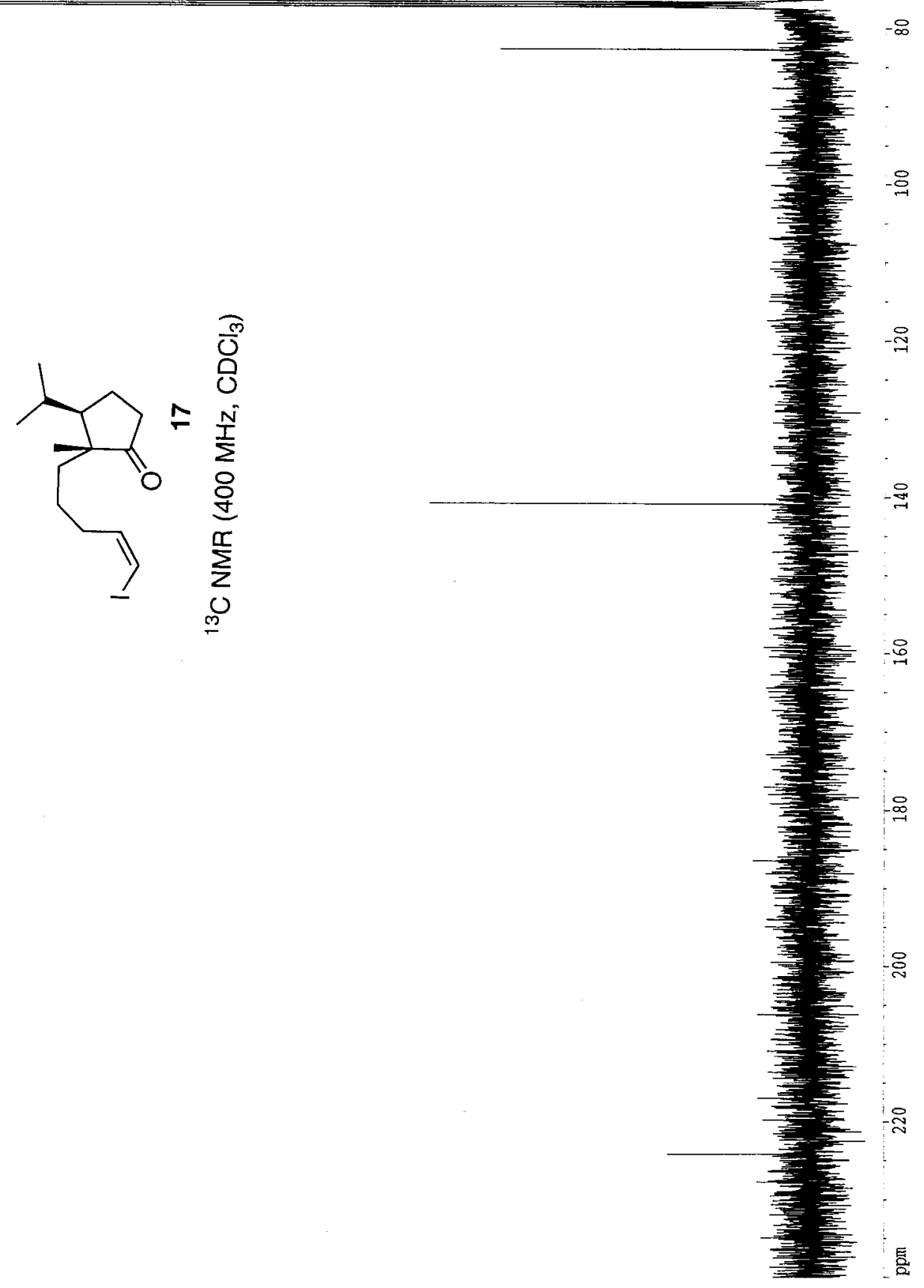

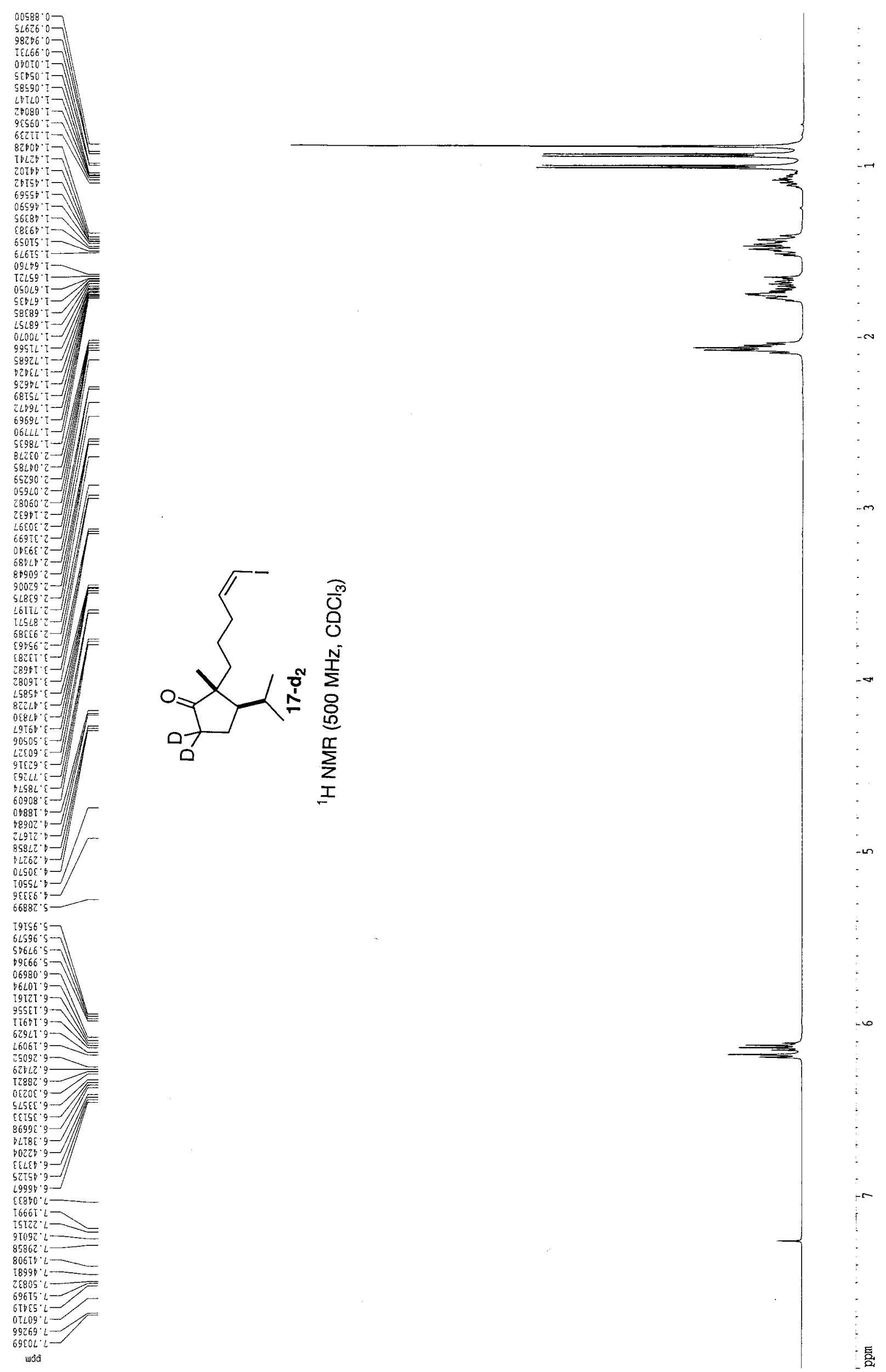


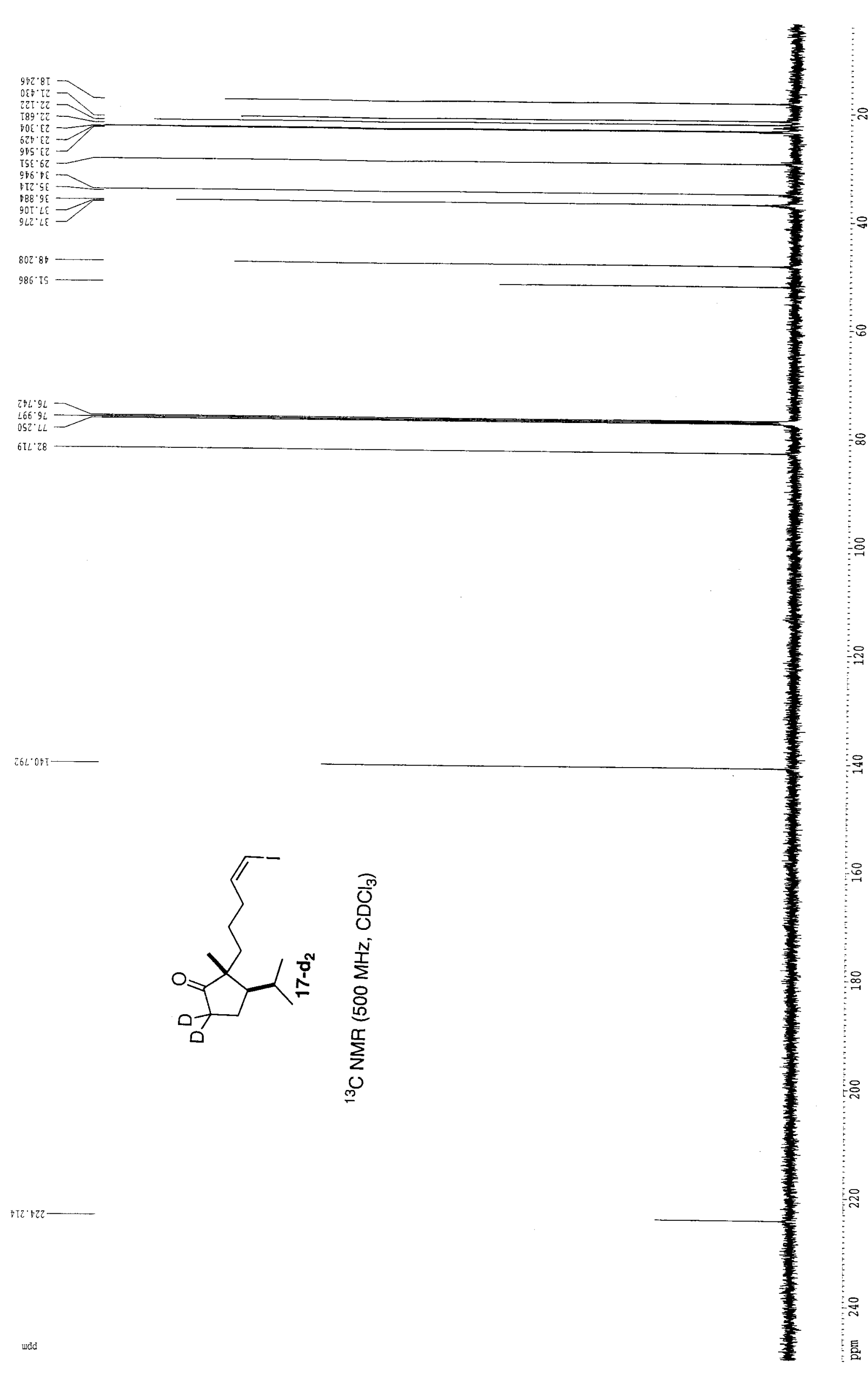

S32 

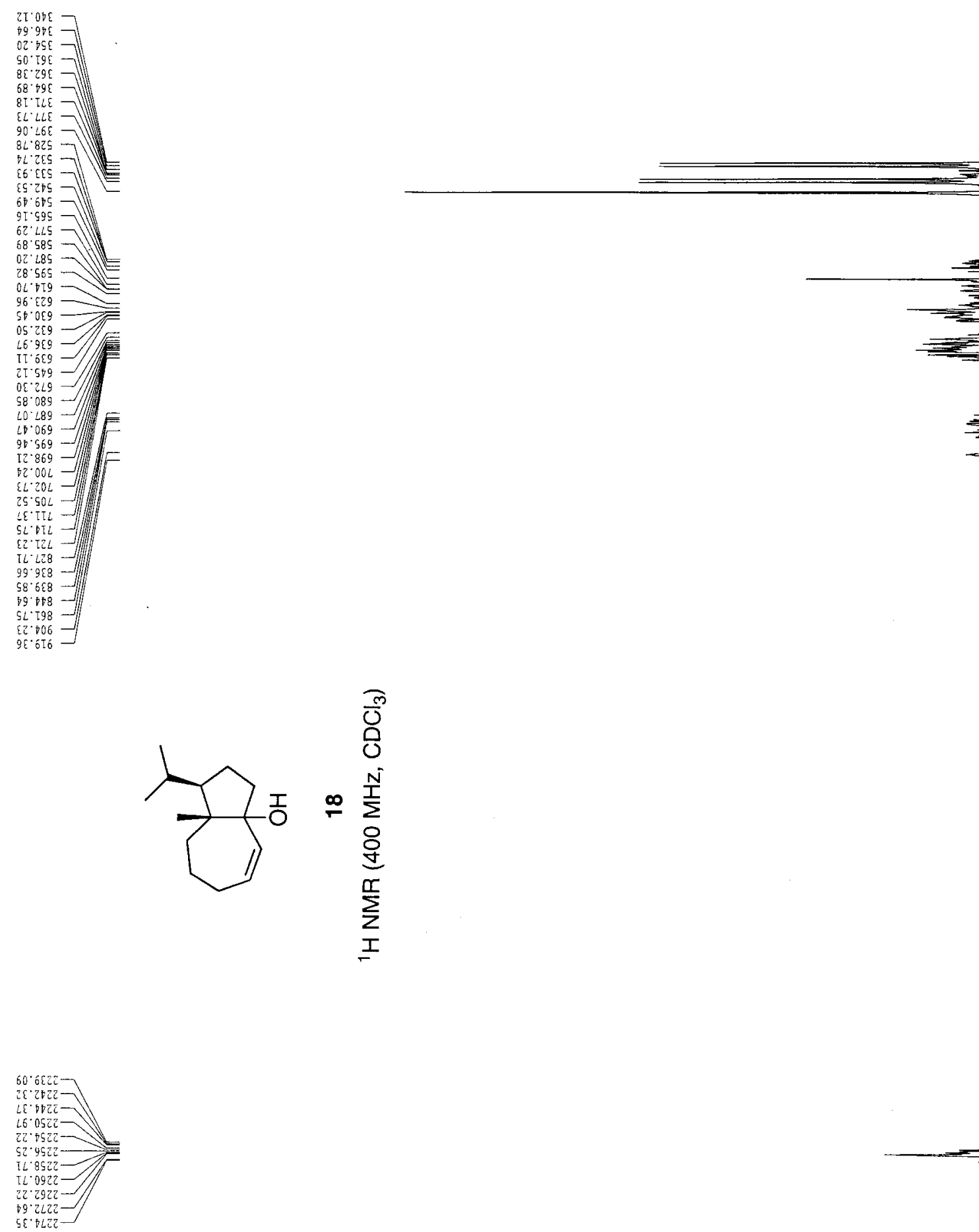

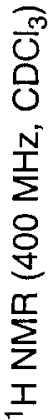



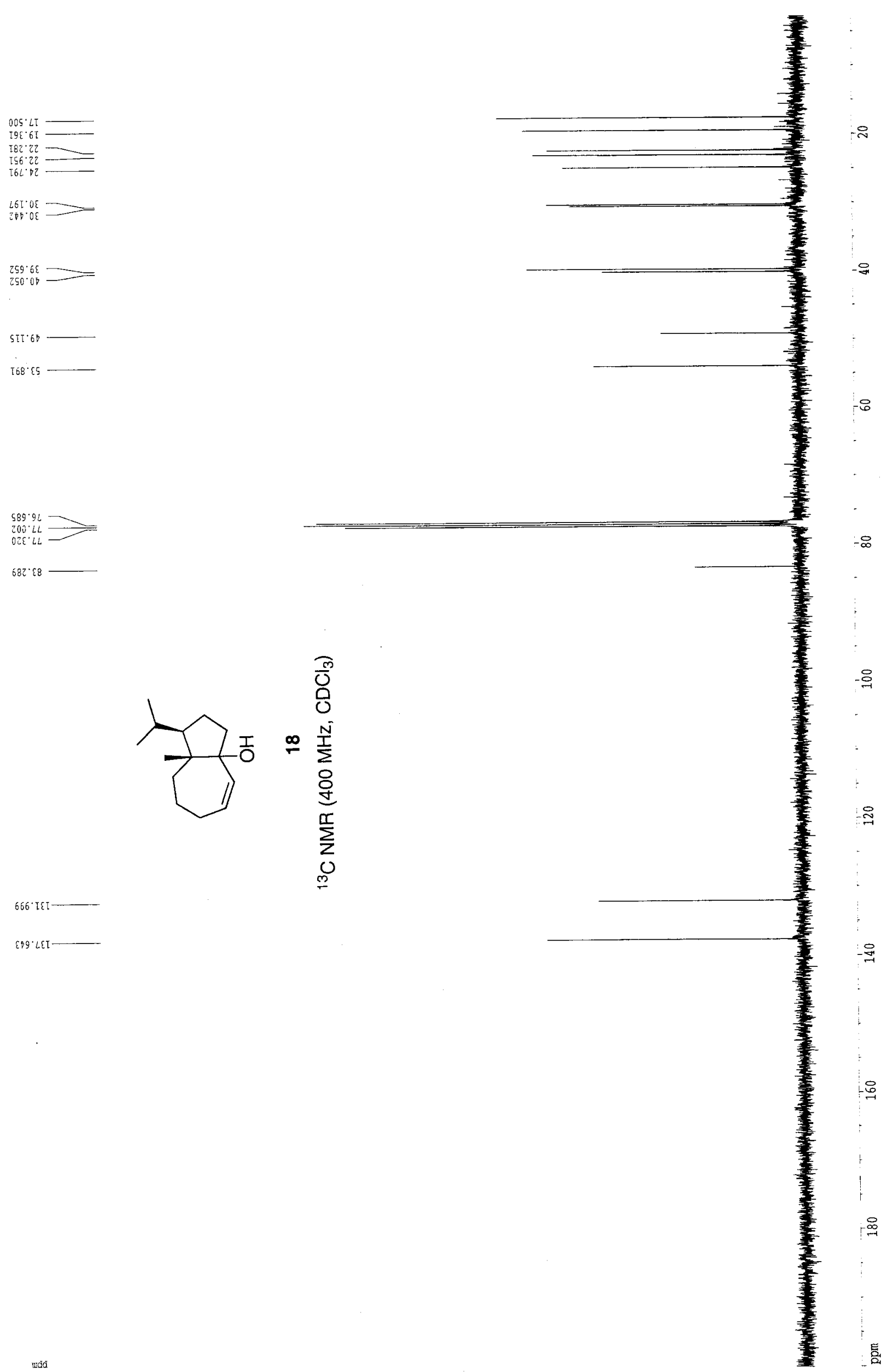

$\gamma_{0}$

$666 \mathrm{k} 20 \mathrm{-}$

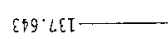




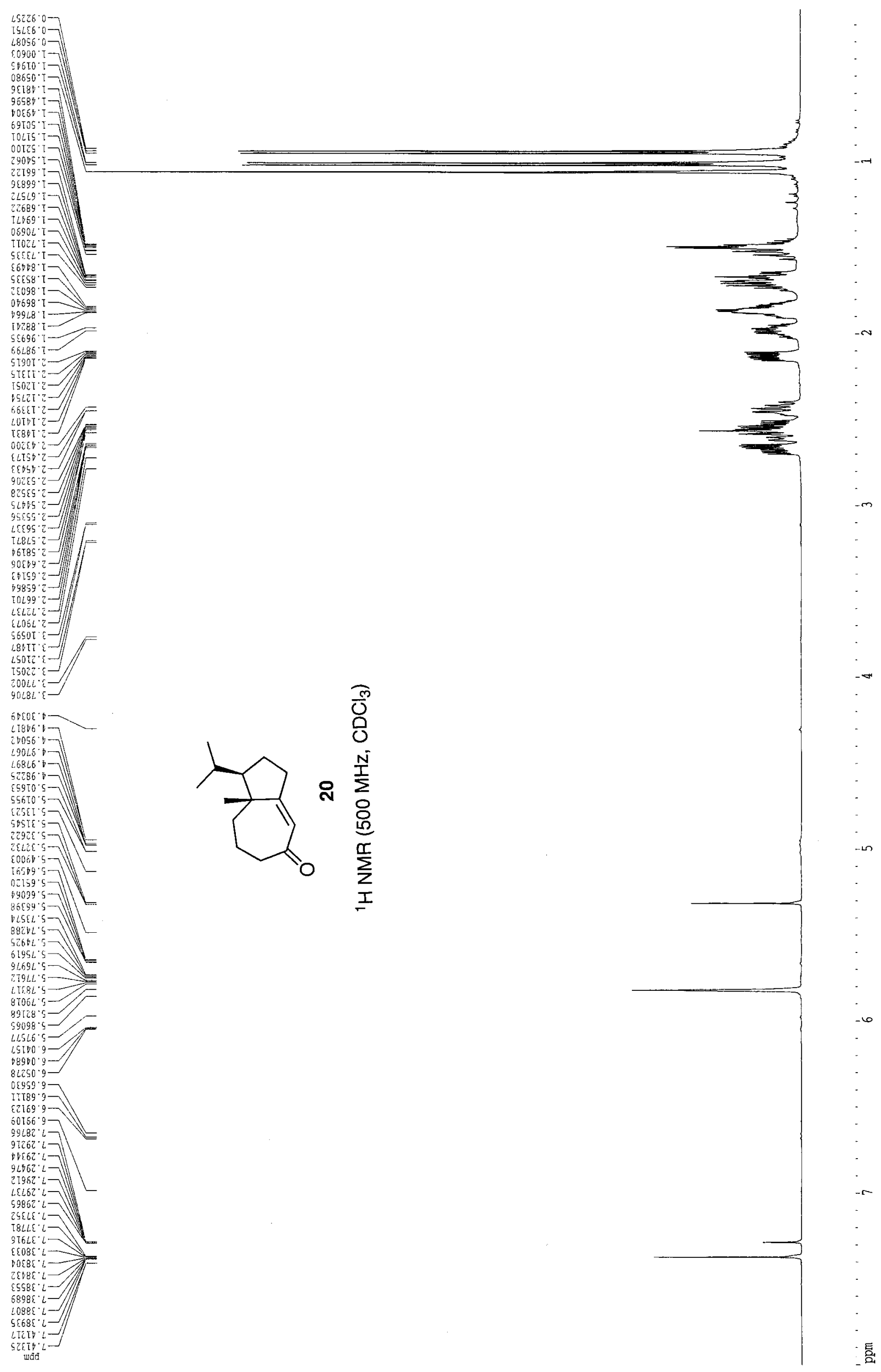




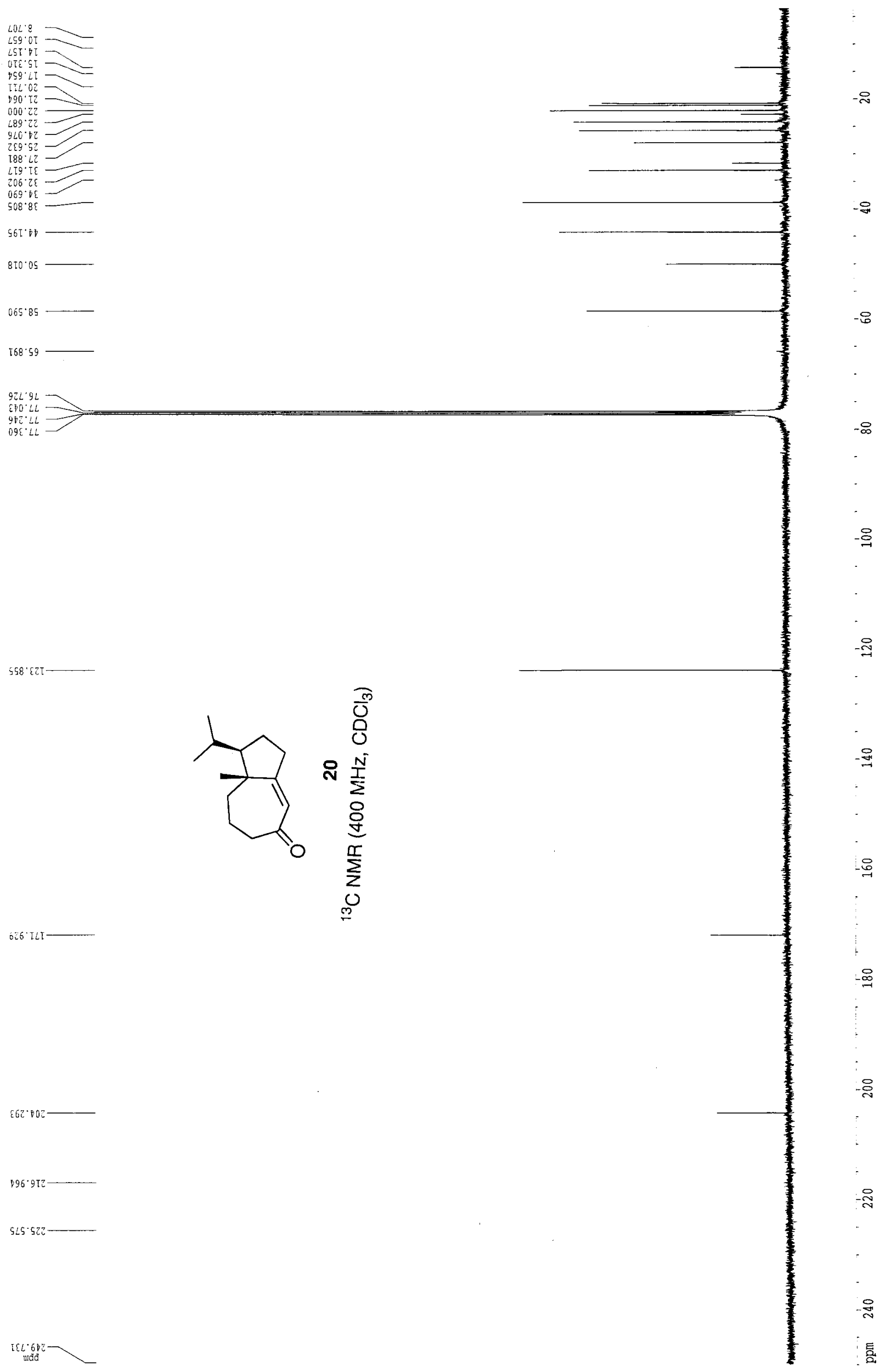



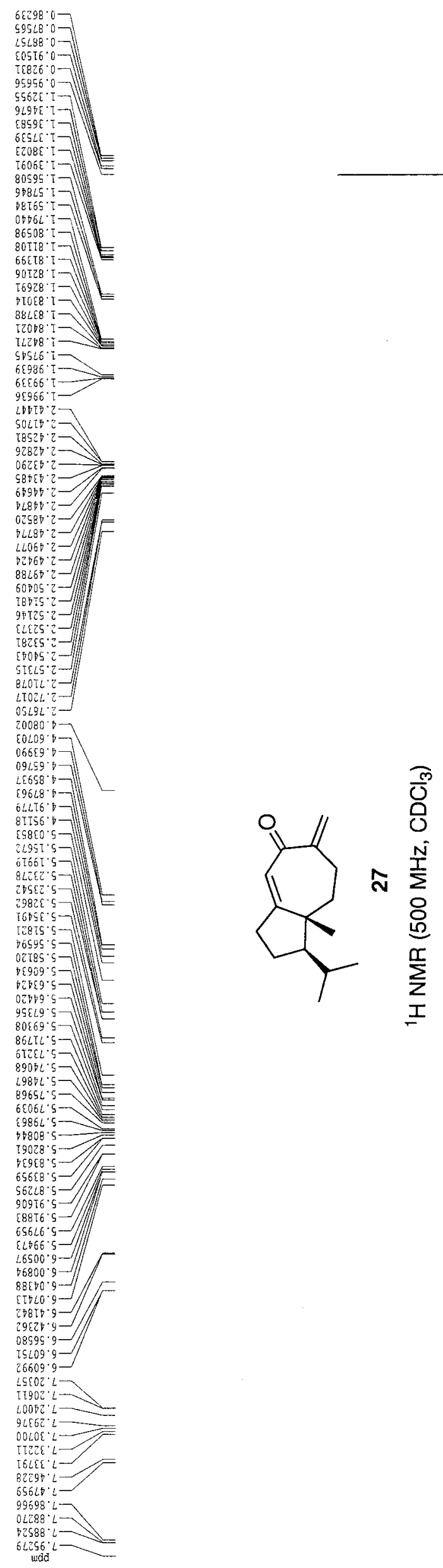

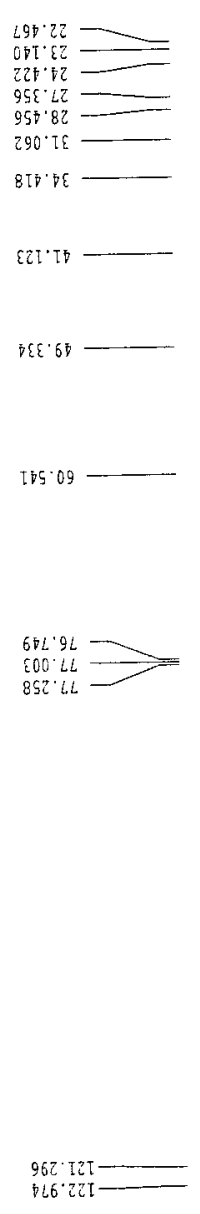

oxcist-

096 625

str:56! -

แä

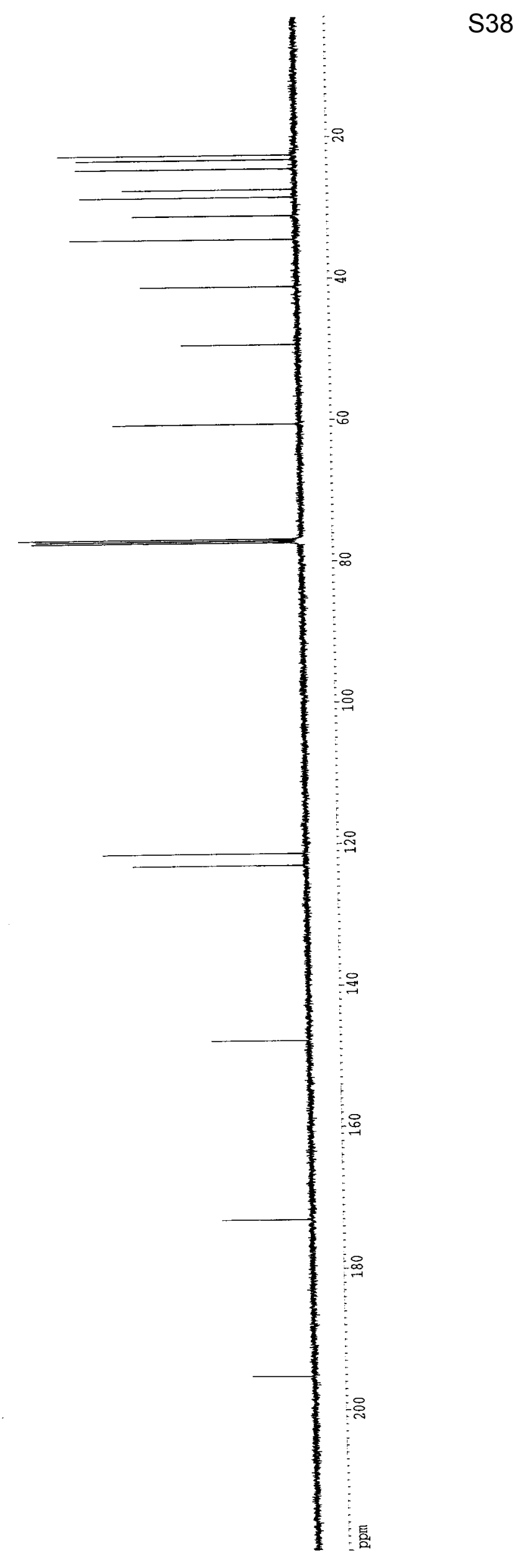




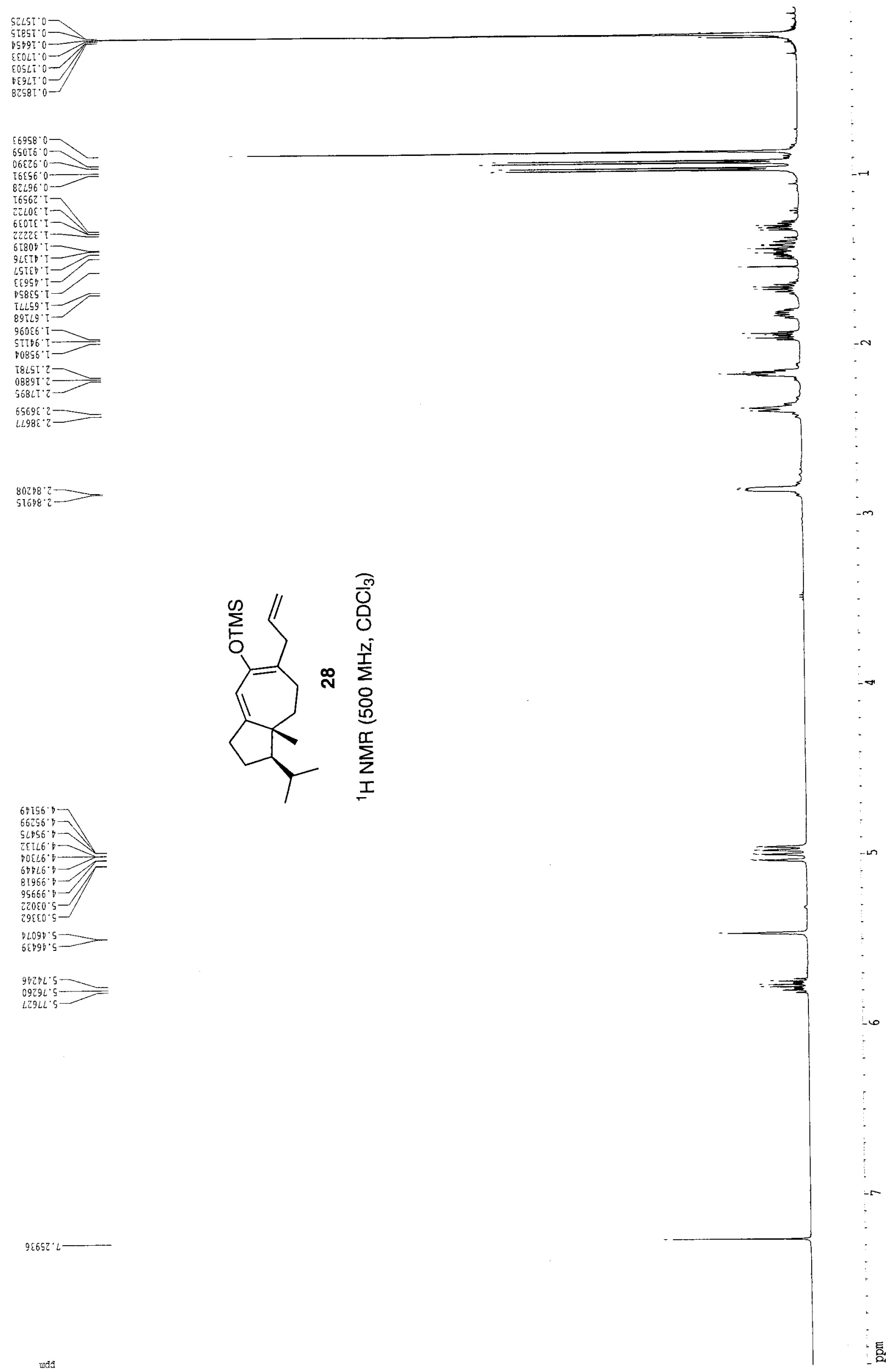


㗂引

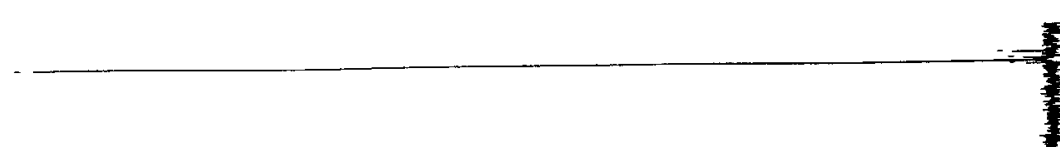

DEL ST -

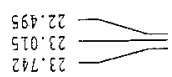

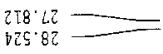

LIE. ZT -

$385 \cdot L E=$
$\angle E T \cdot 8 E=$

SS6' $9 \overline{\mathrm{V}}$

$667^{\circ} 85$

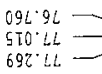

$\angle 5 g \cdot \mathrm{DIT}-$
$\angle 58^{\circ} \angle \mathrm{LT}=$
$5 L L \cdot 6 \mathrm{IT}$

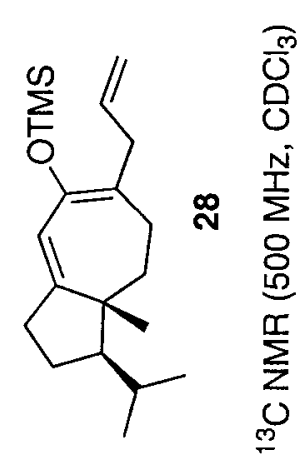

BIT $\angle โ T-$

gze'tpז——_.

$6 T \cdot 65$

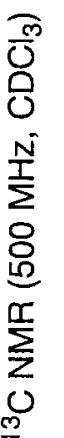

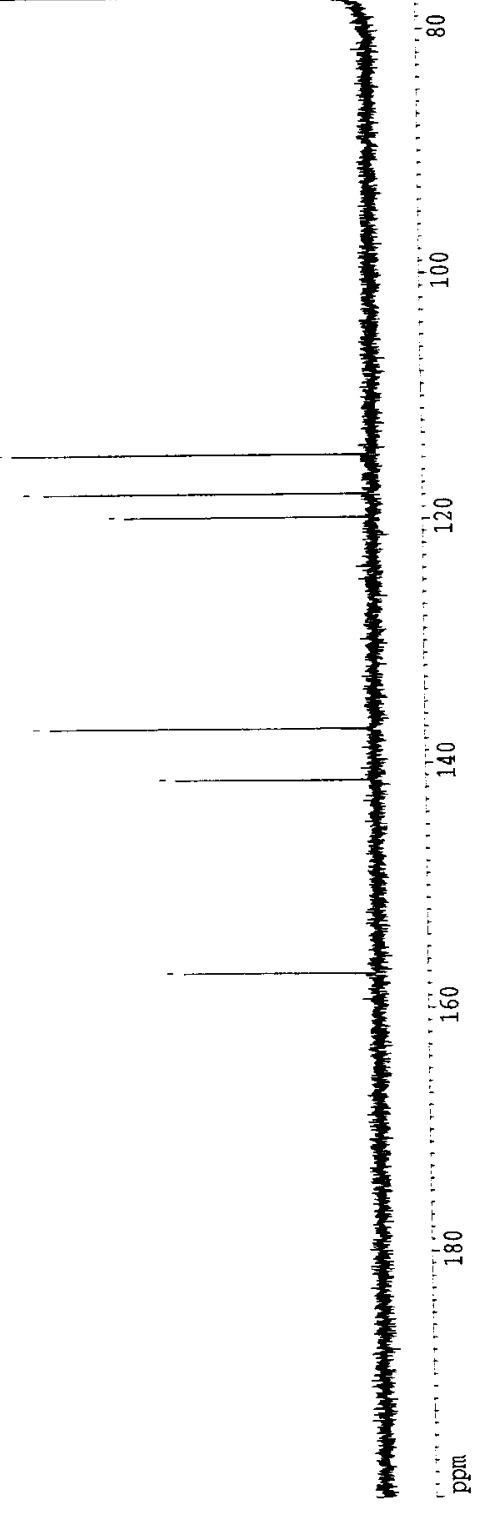




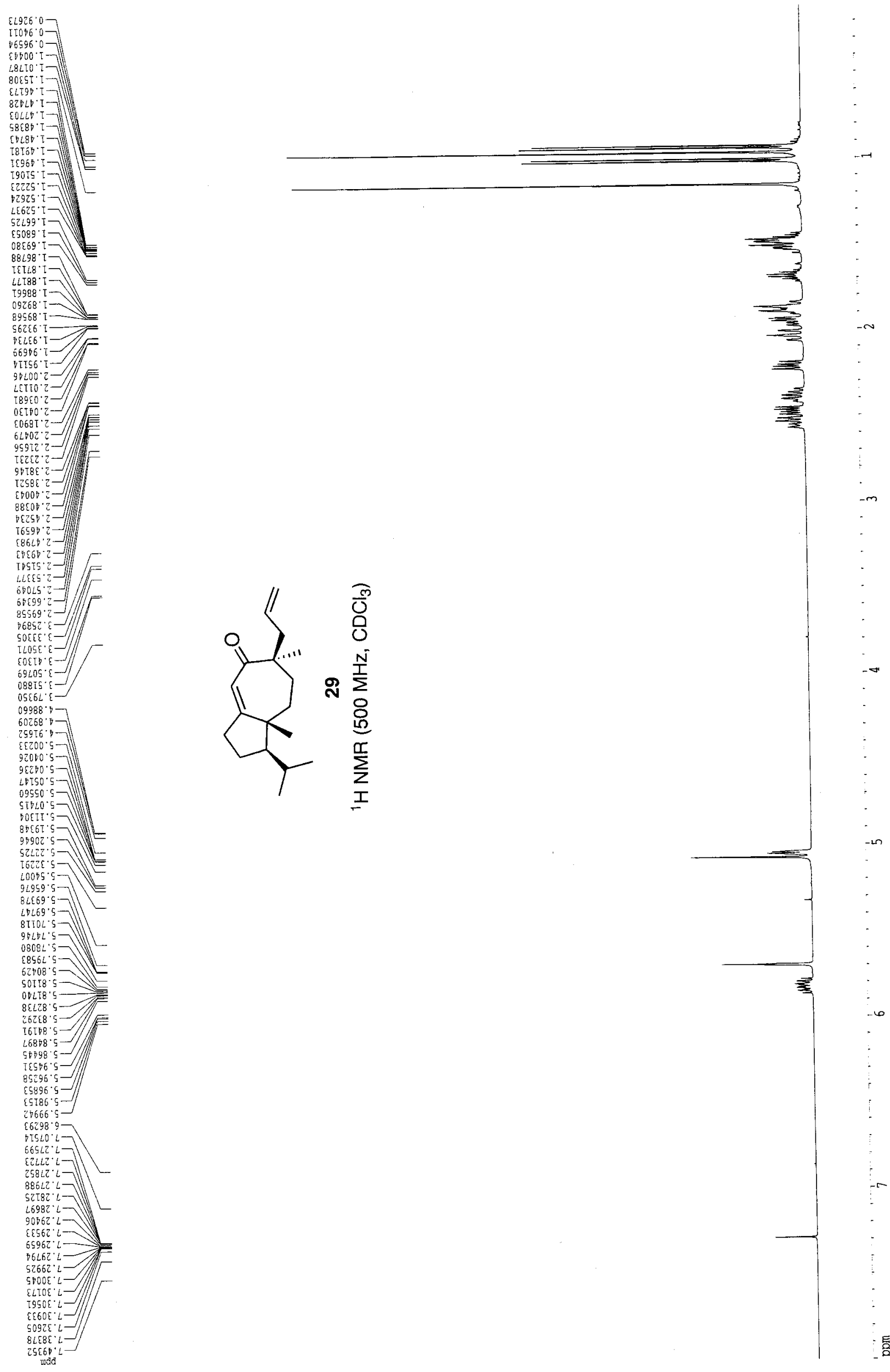




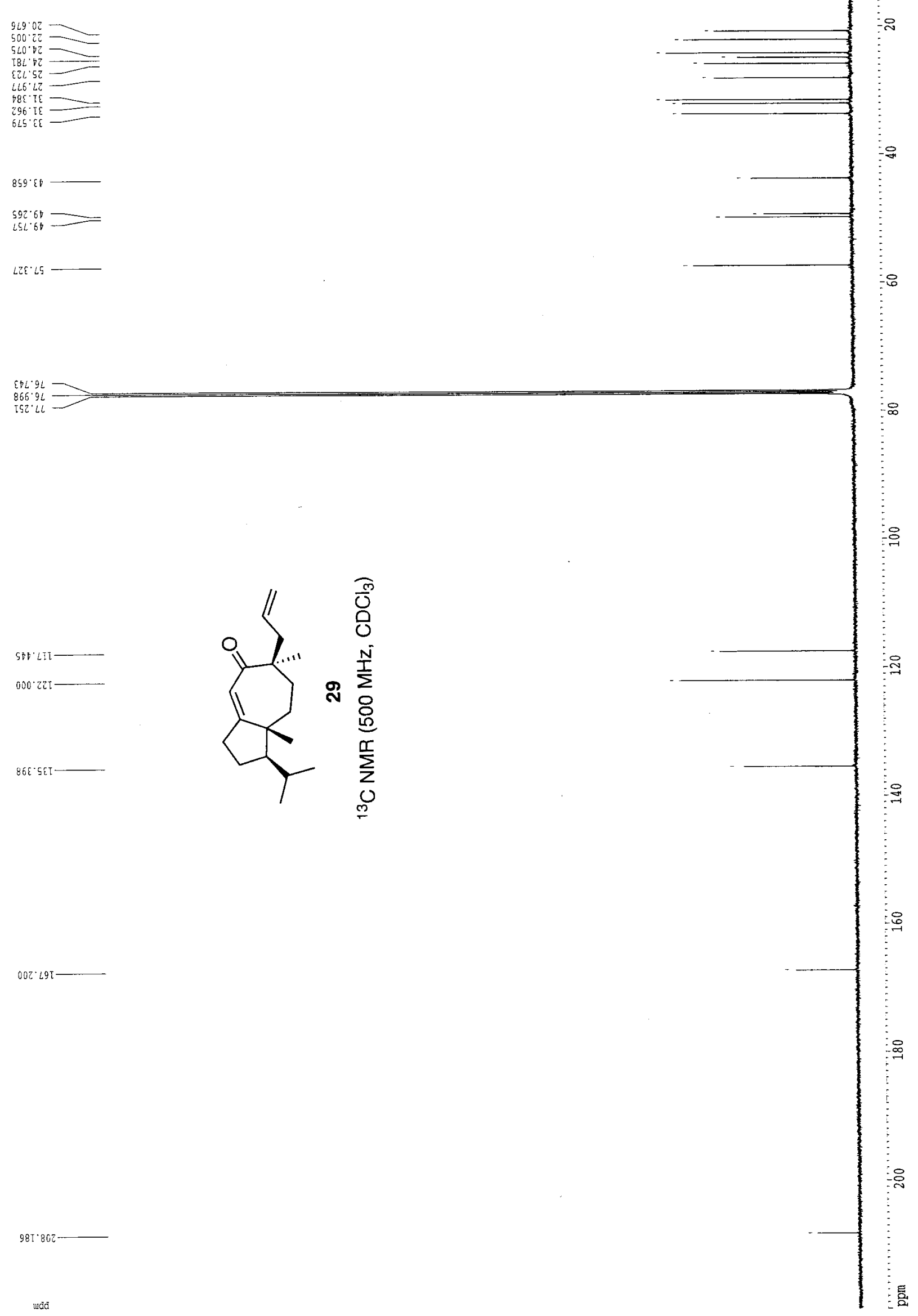




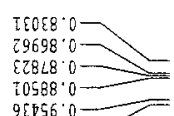

ios $0588^{\circ} 0$

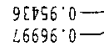

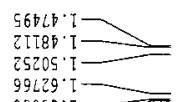

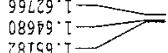

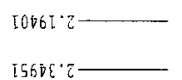

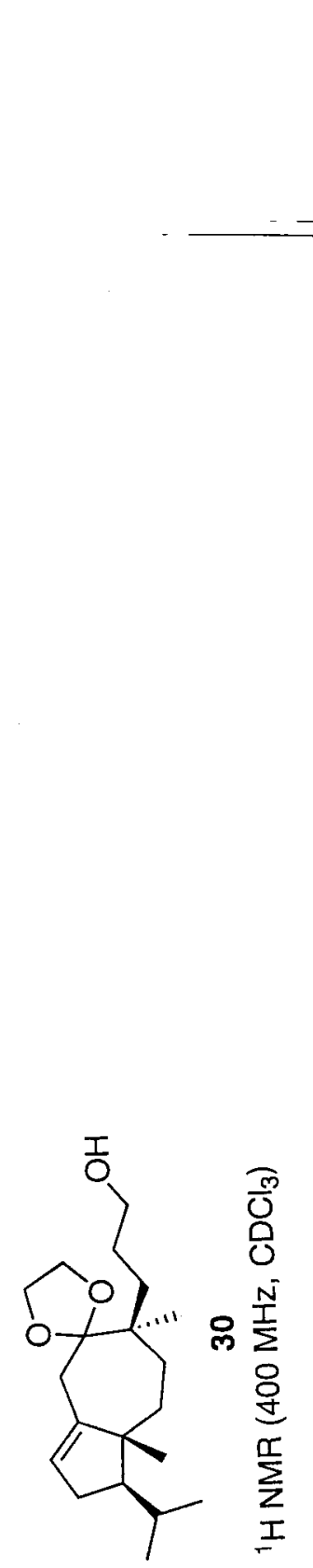

$0 z 29 \varepsilon^{\circ} 5$

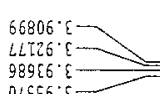

年

(and 


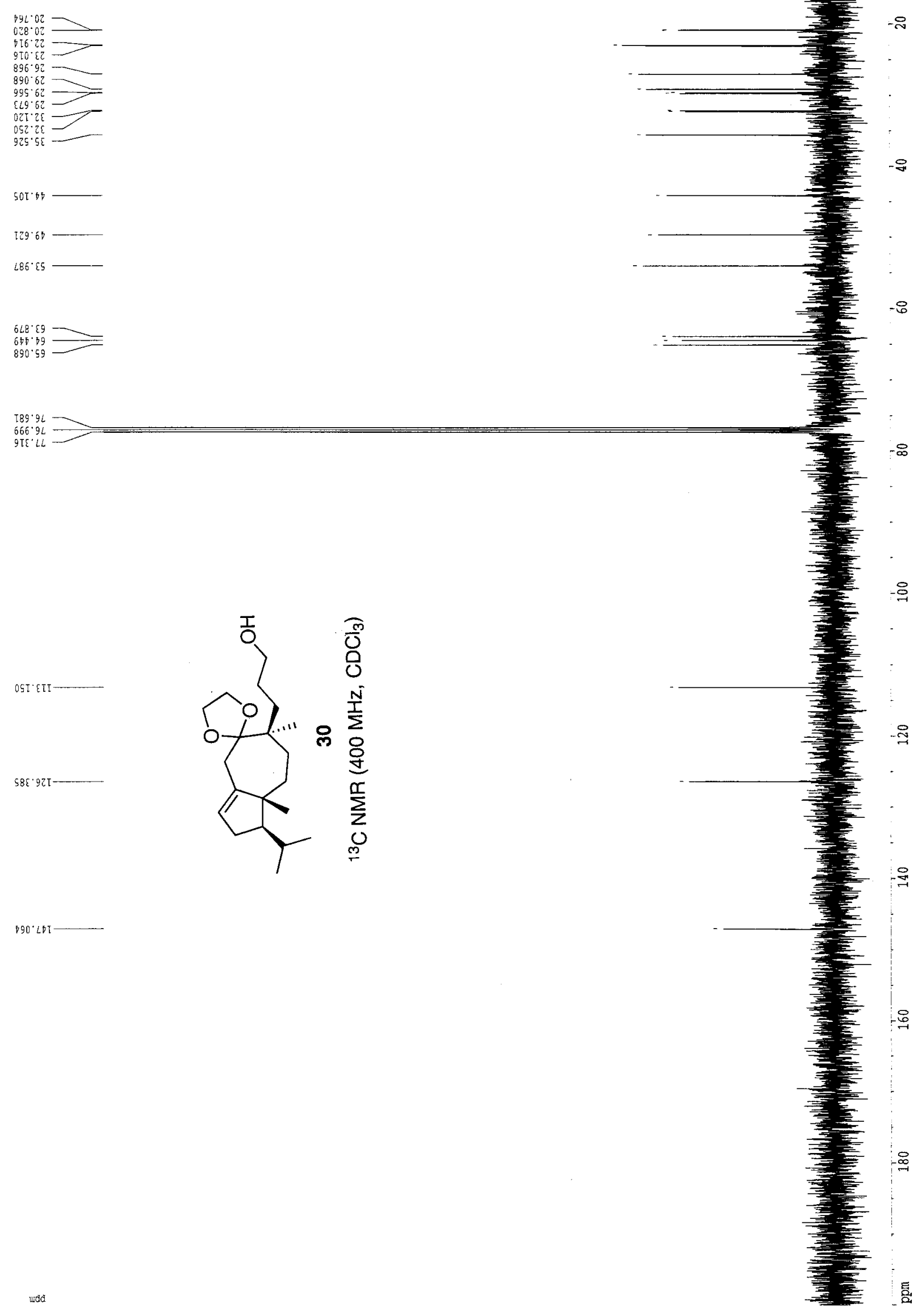



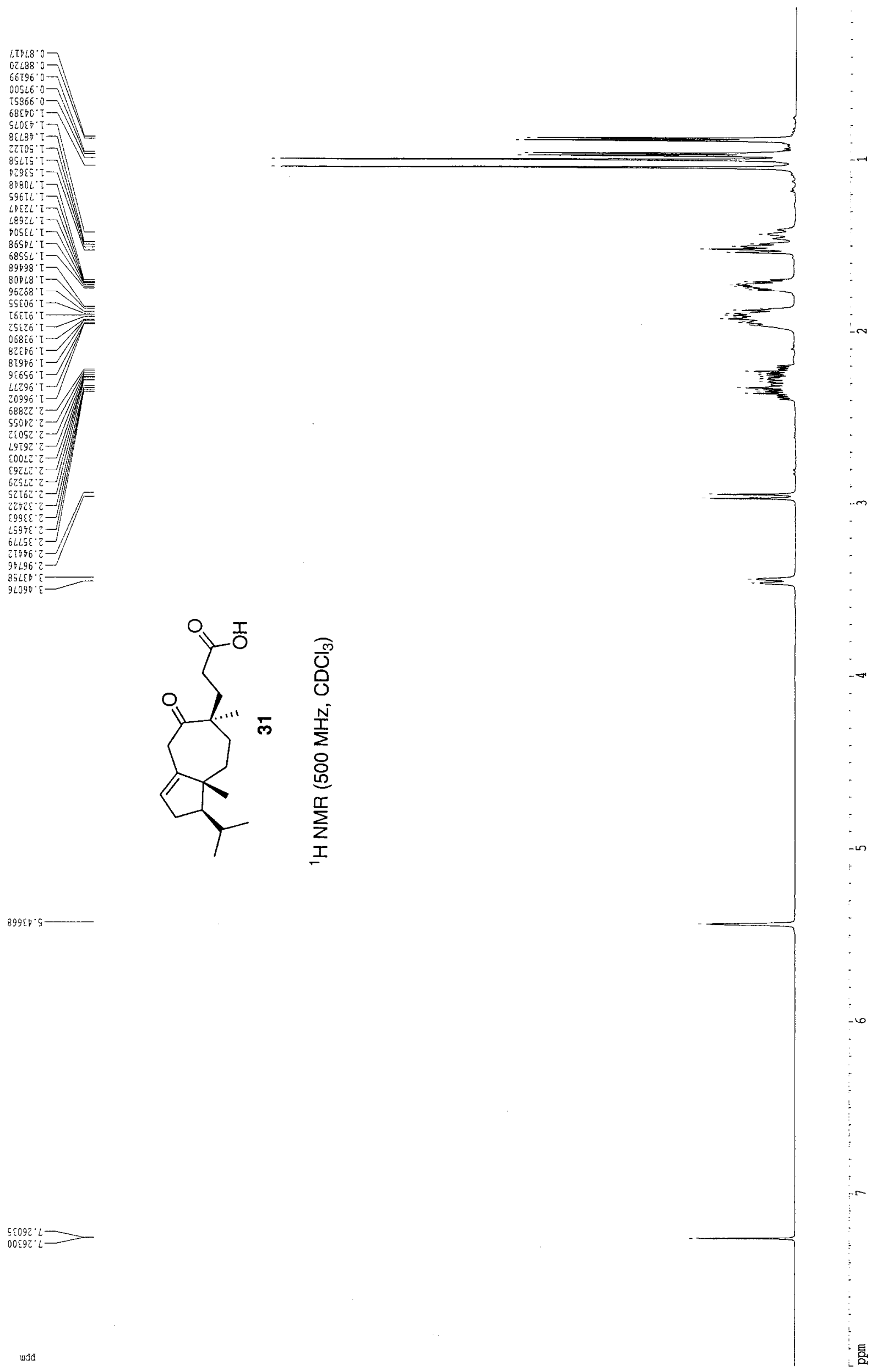

899605 


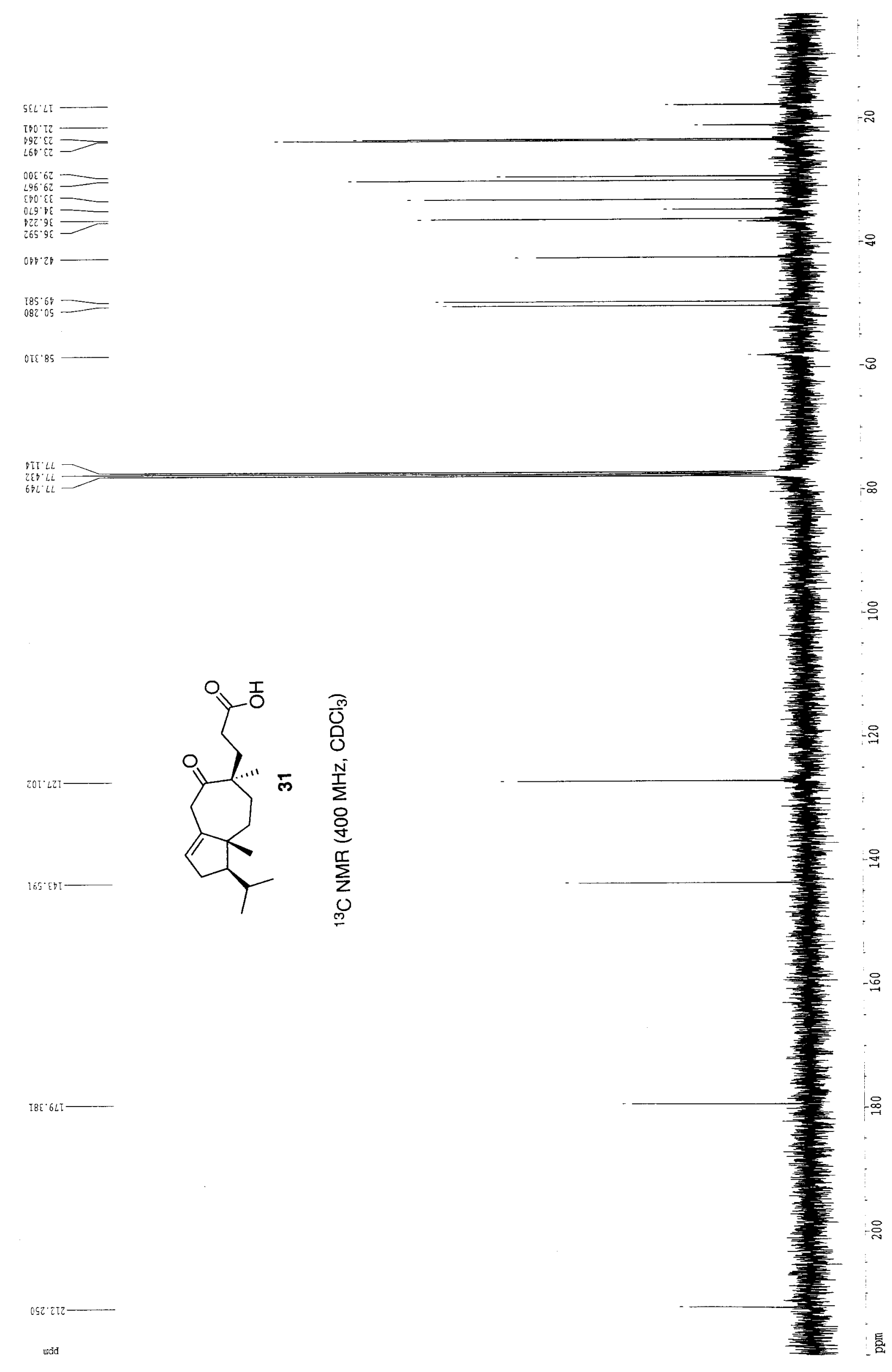




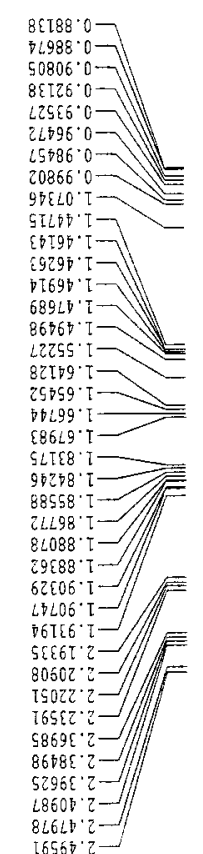

$\underbrace{\infty}_{\infty}$

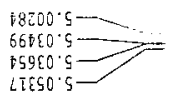

年

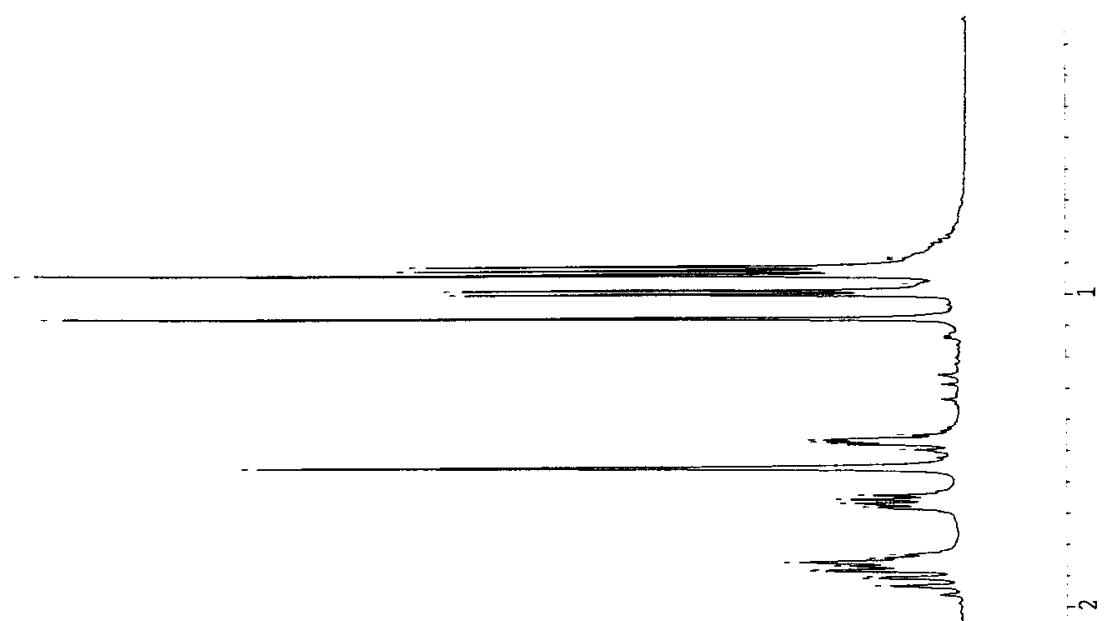




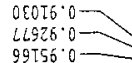

年

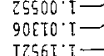

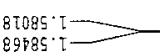

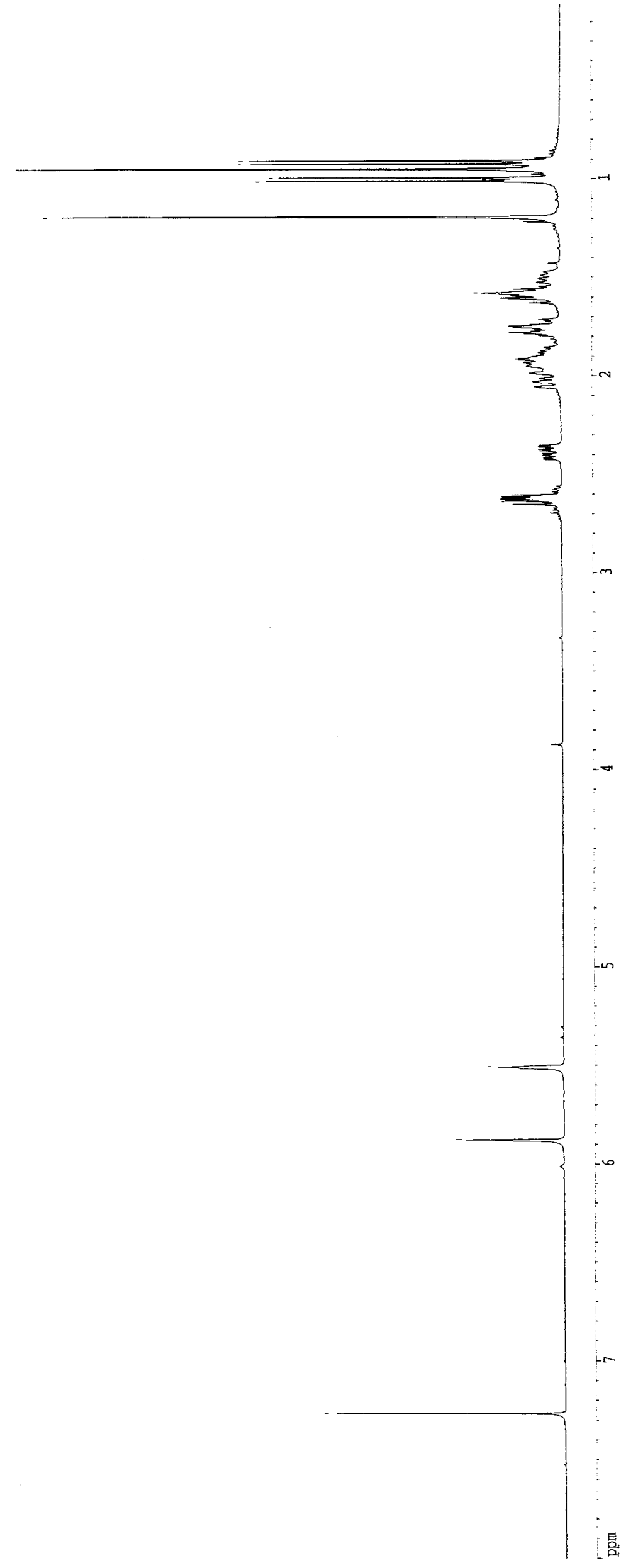

$06605 \cdot 9+2$

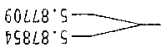

$28892^{\circ}\llcorner$

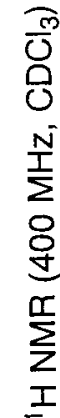




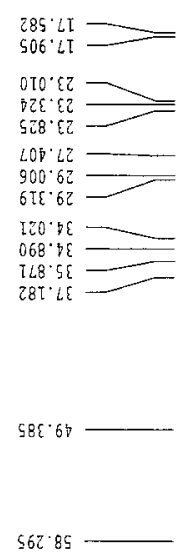

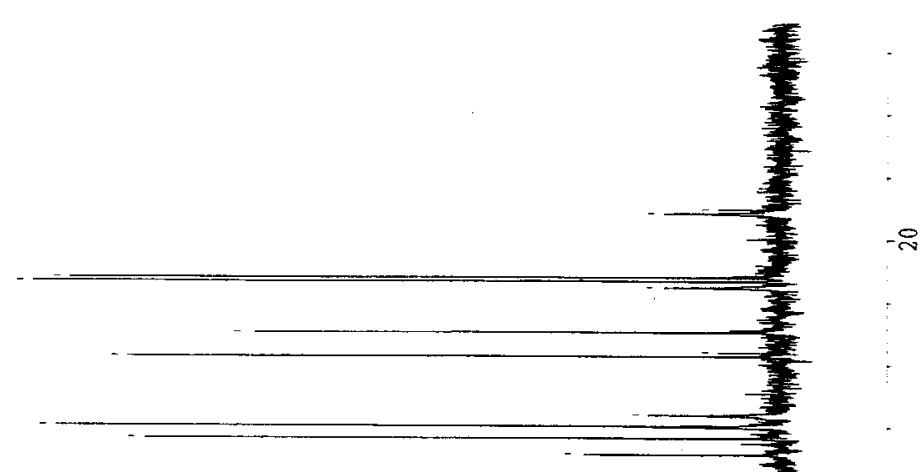

829.94
96696

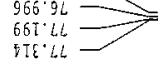

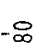

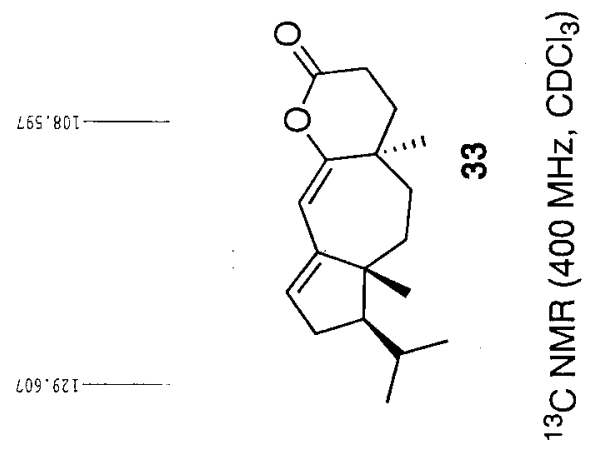

$I E l \mathcal{S}_{\mathrm{S}} \mathrm{T}$

STE' BST 


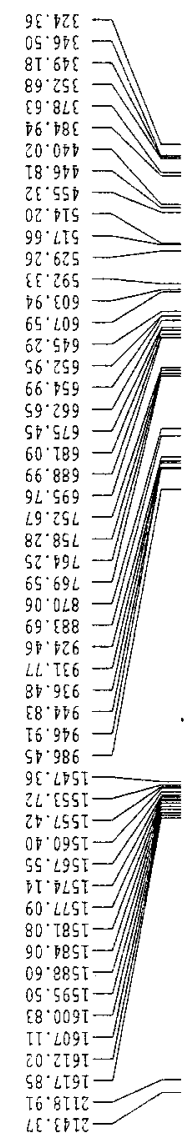

LT 5062
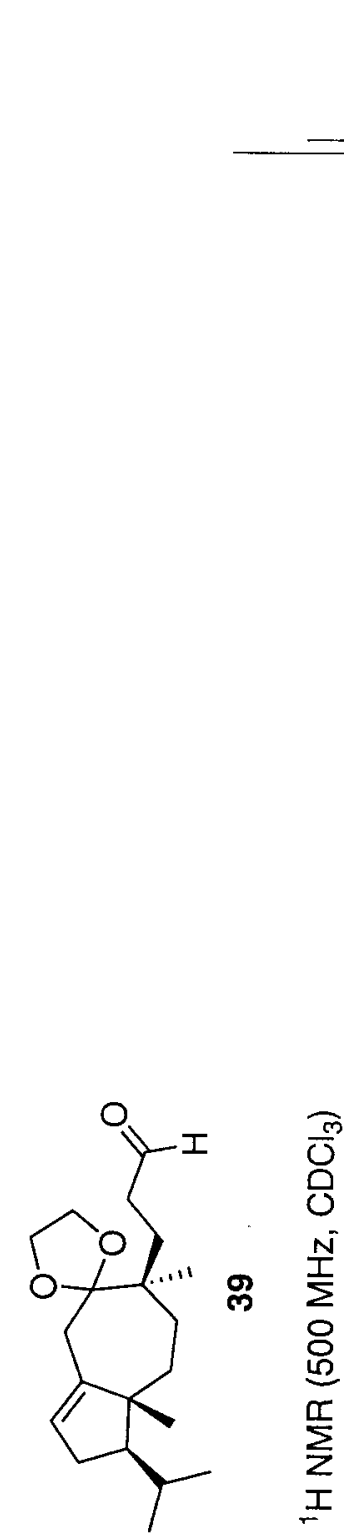

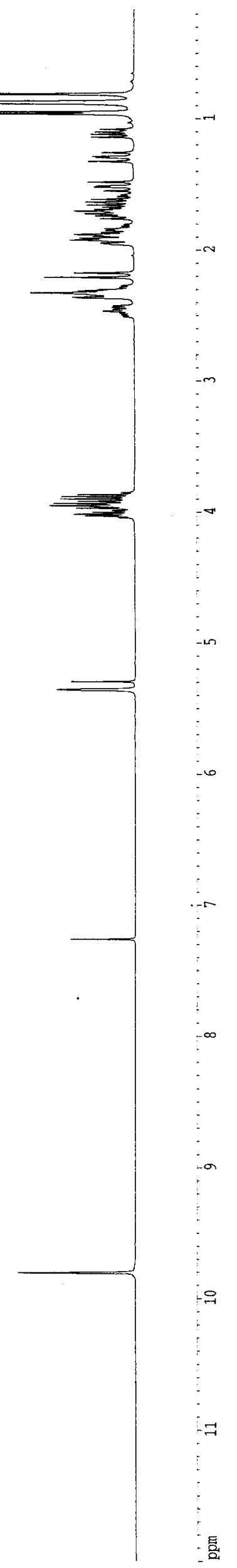




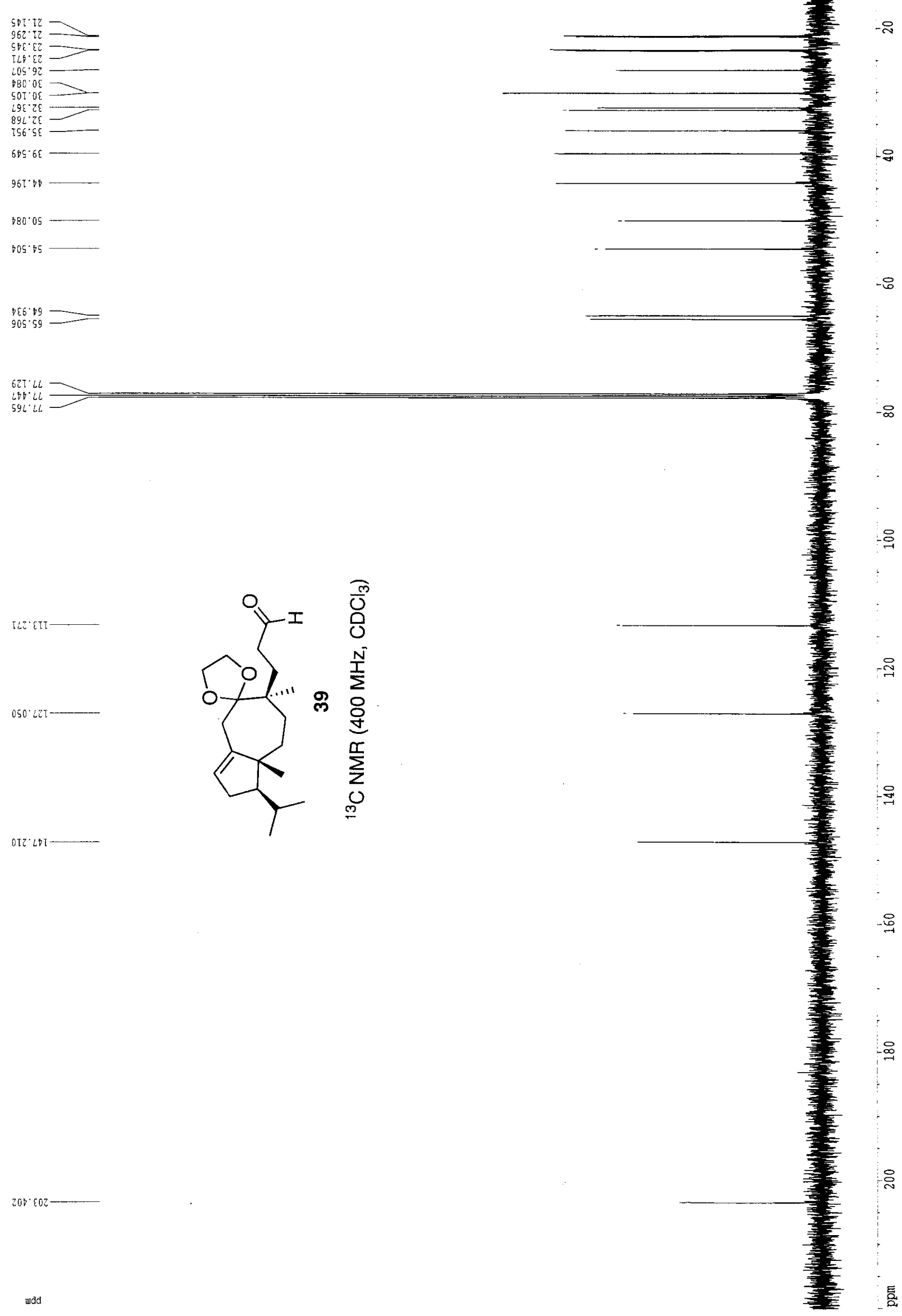




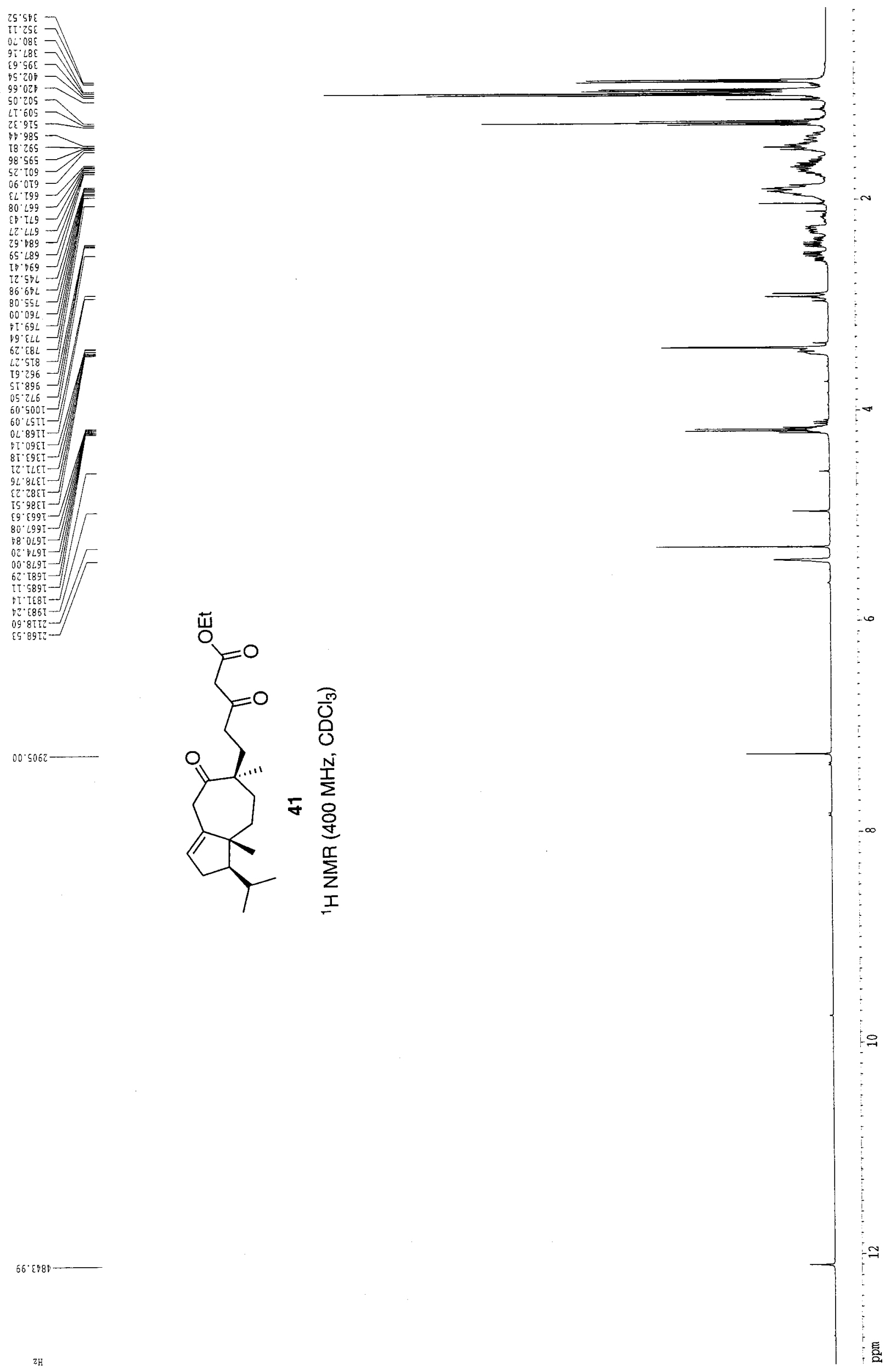




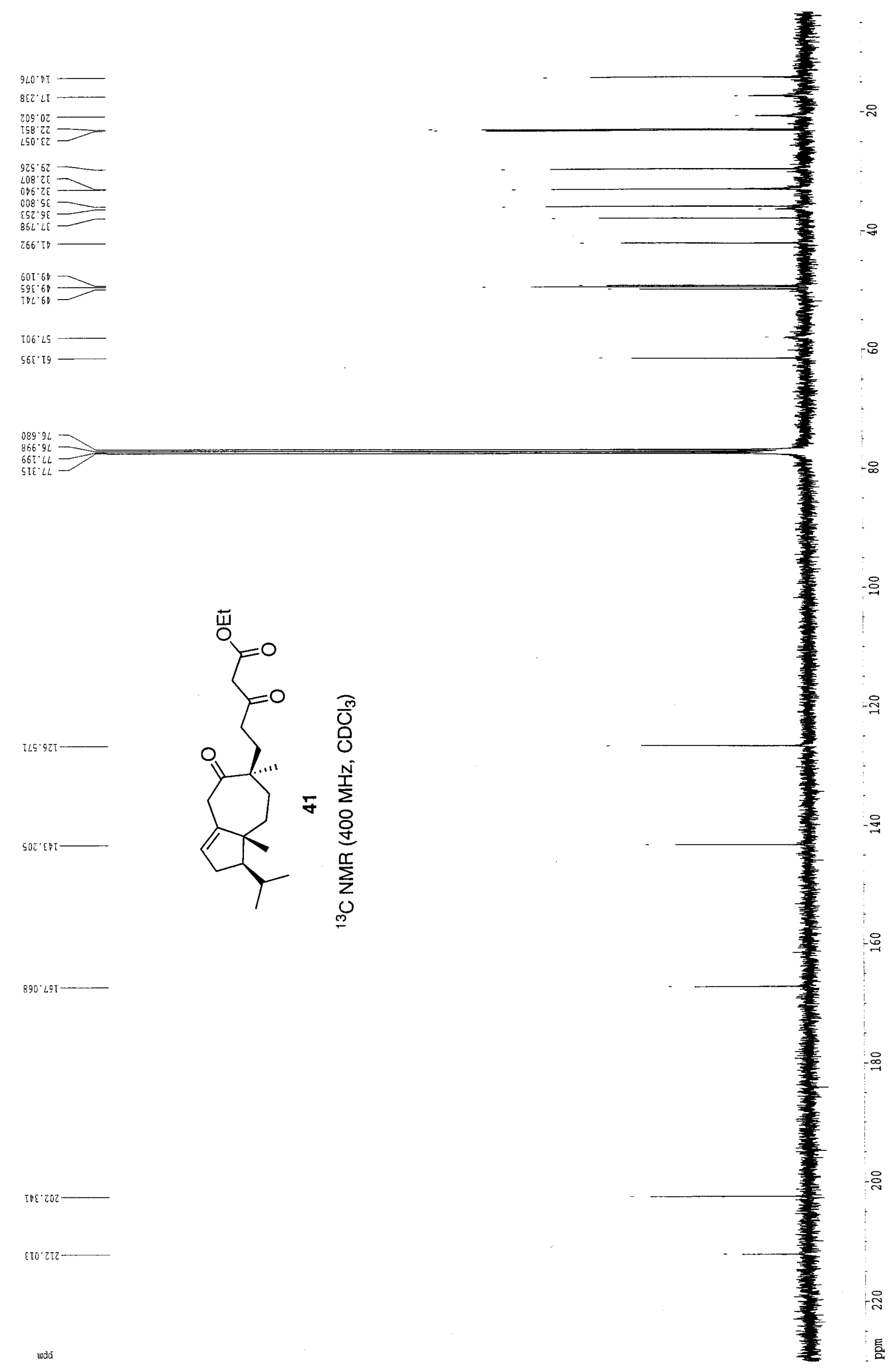




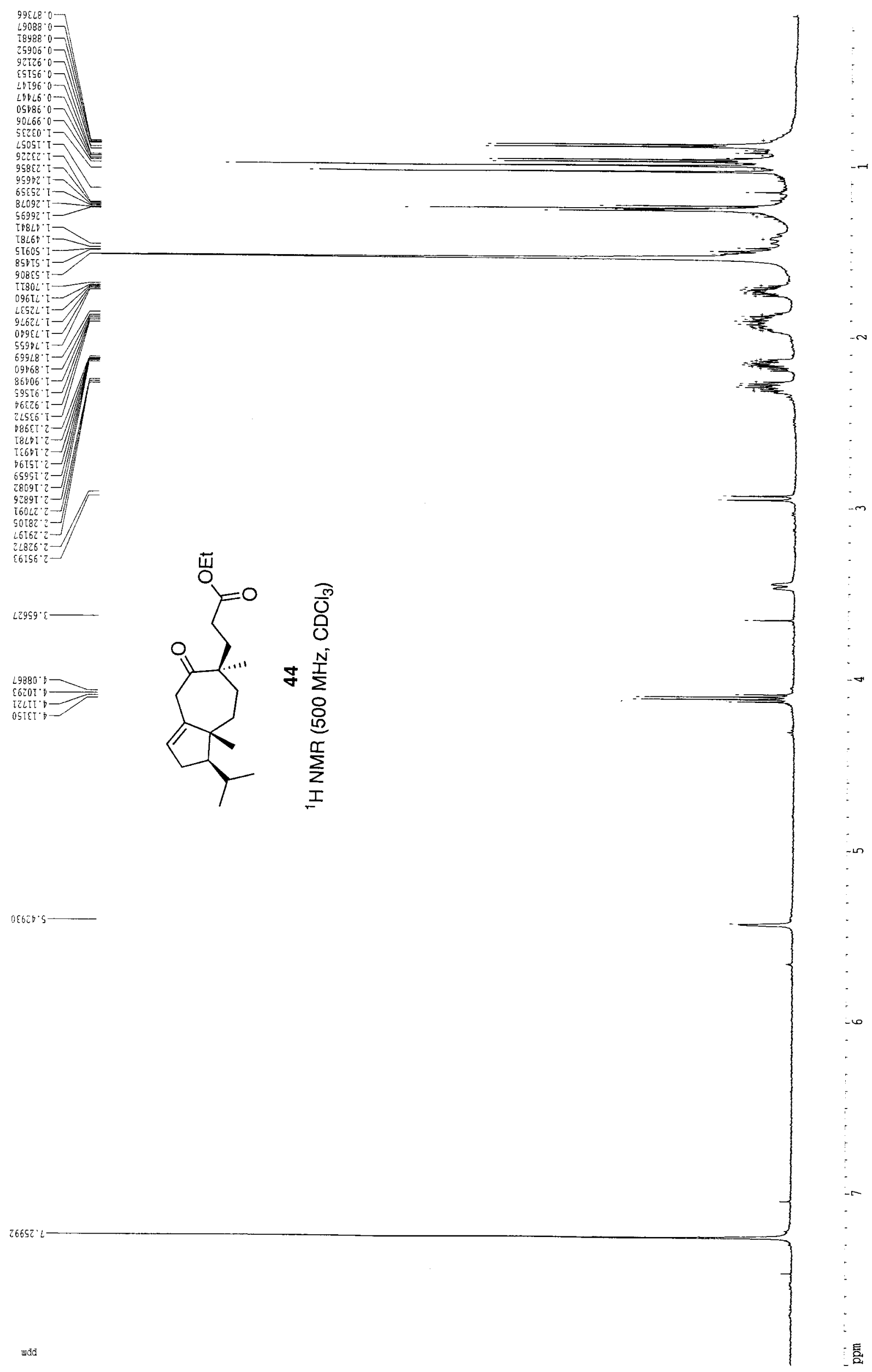




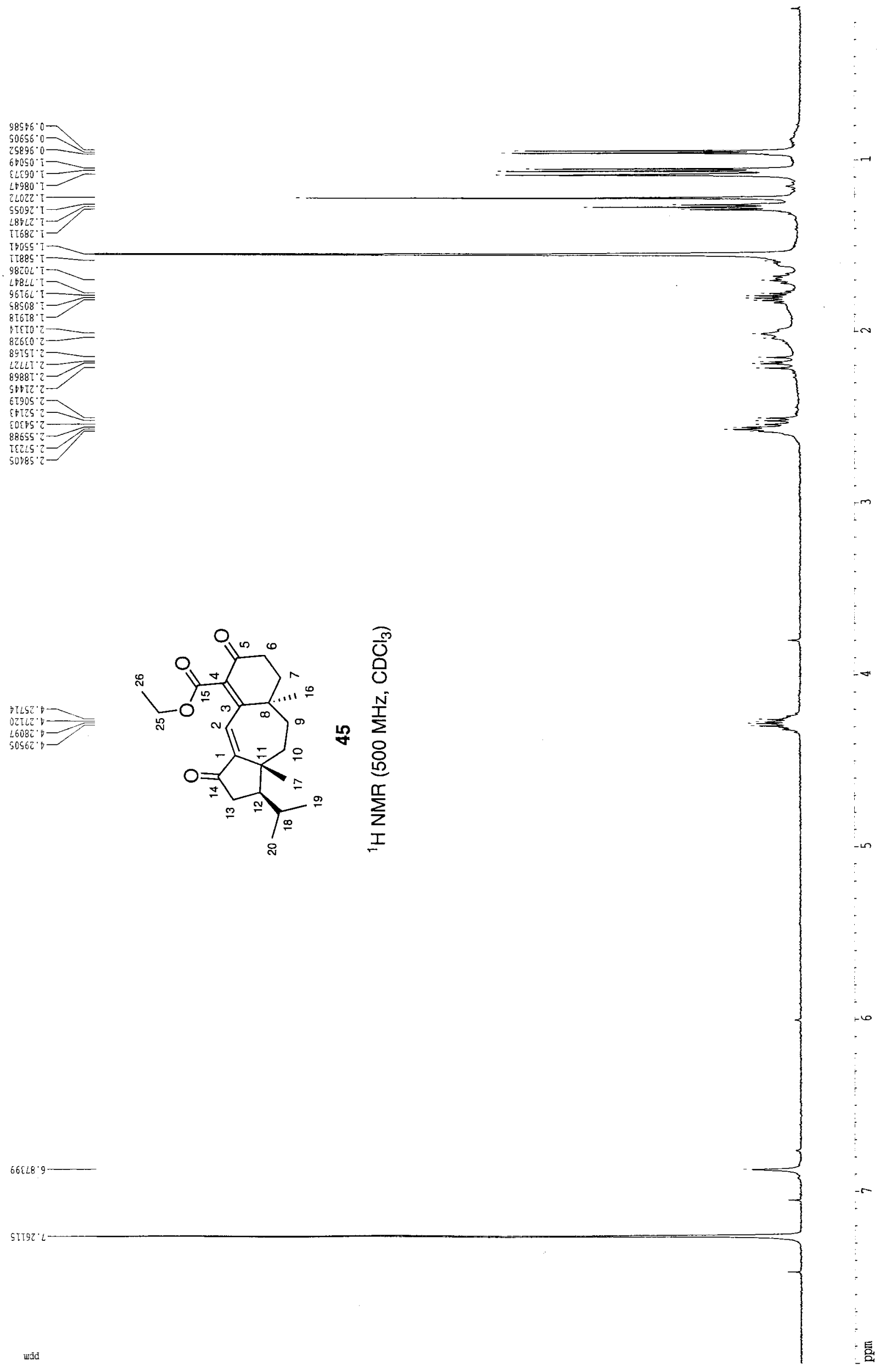




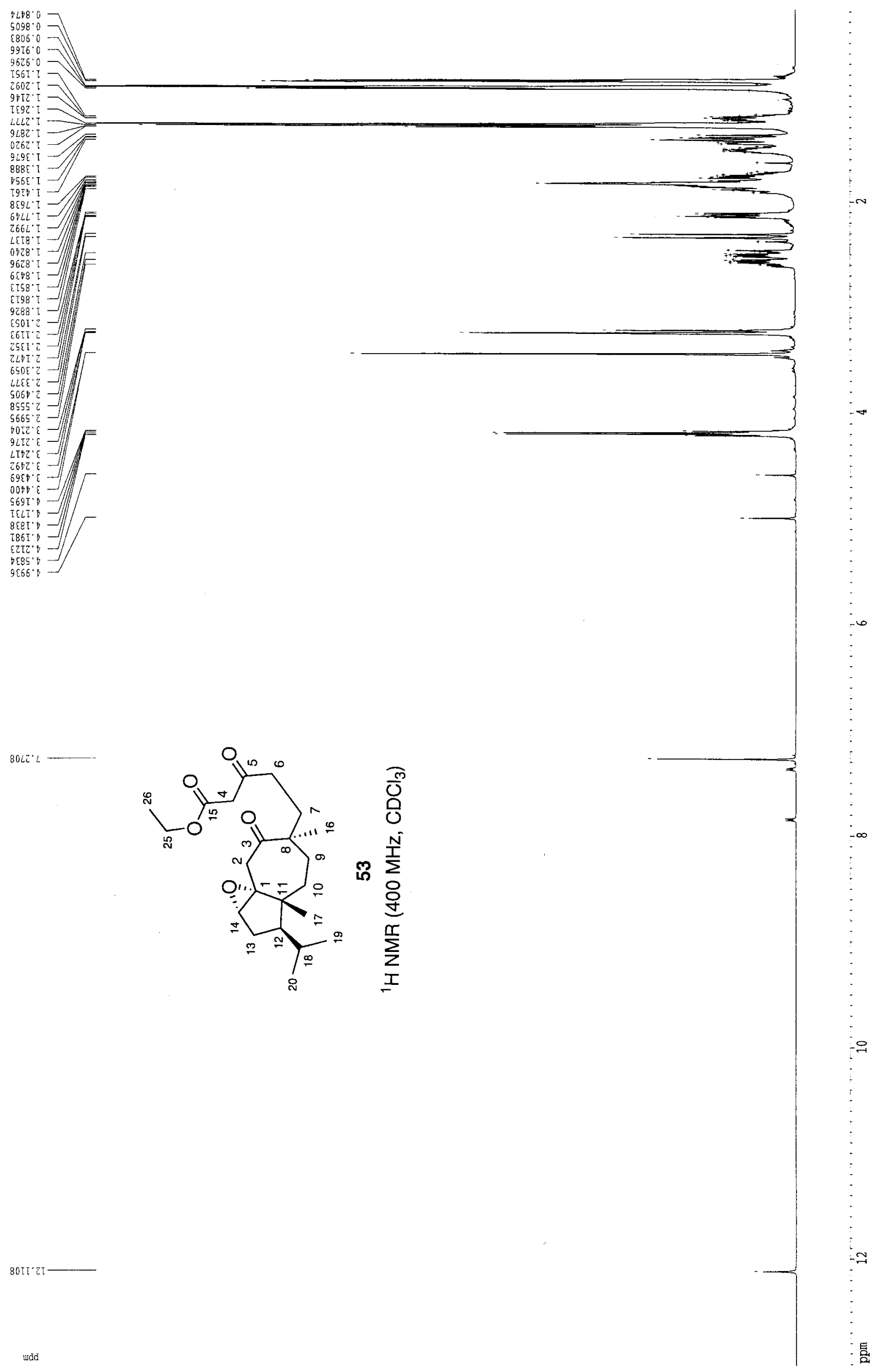




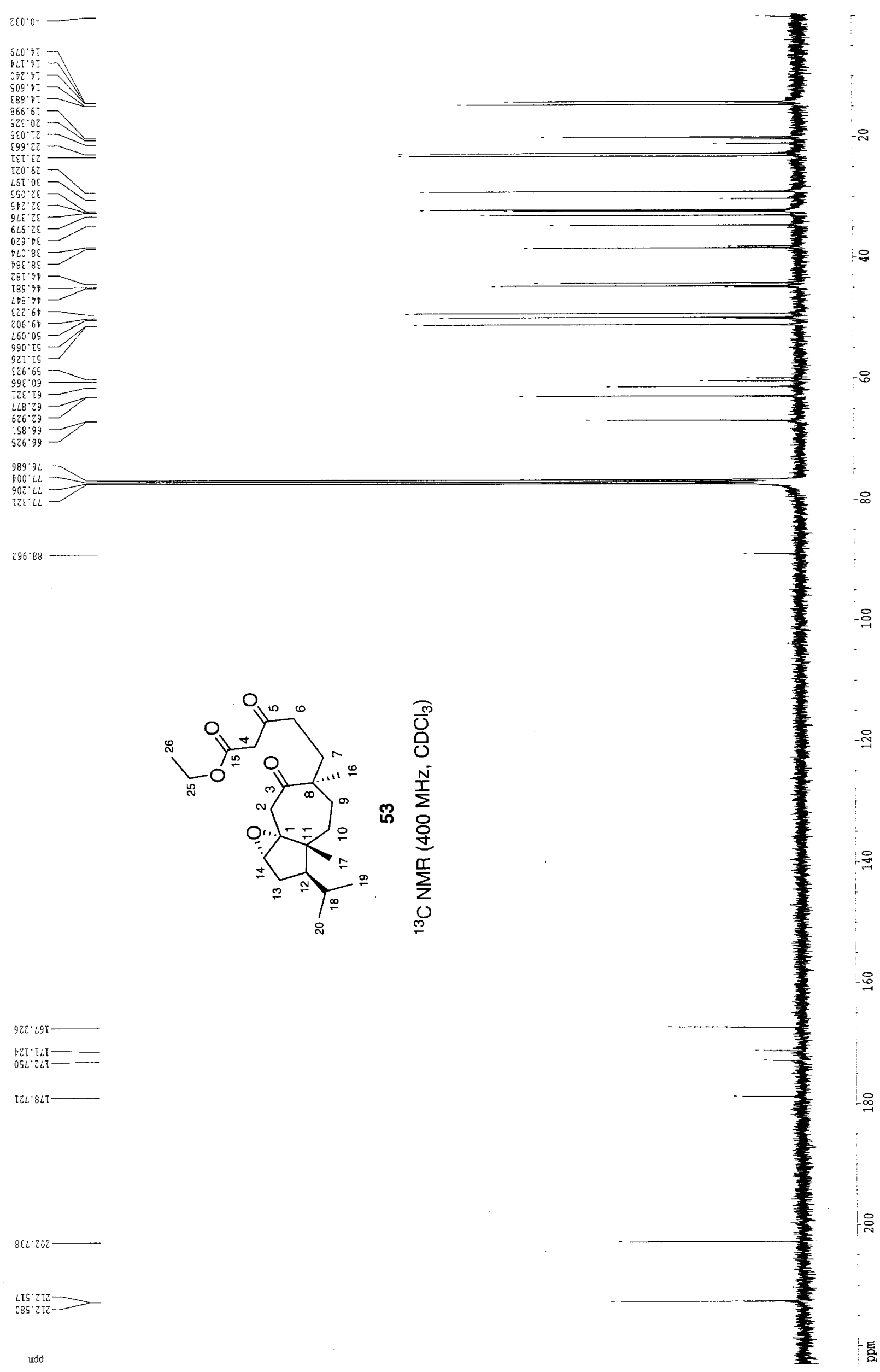



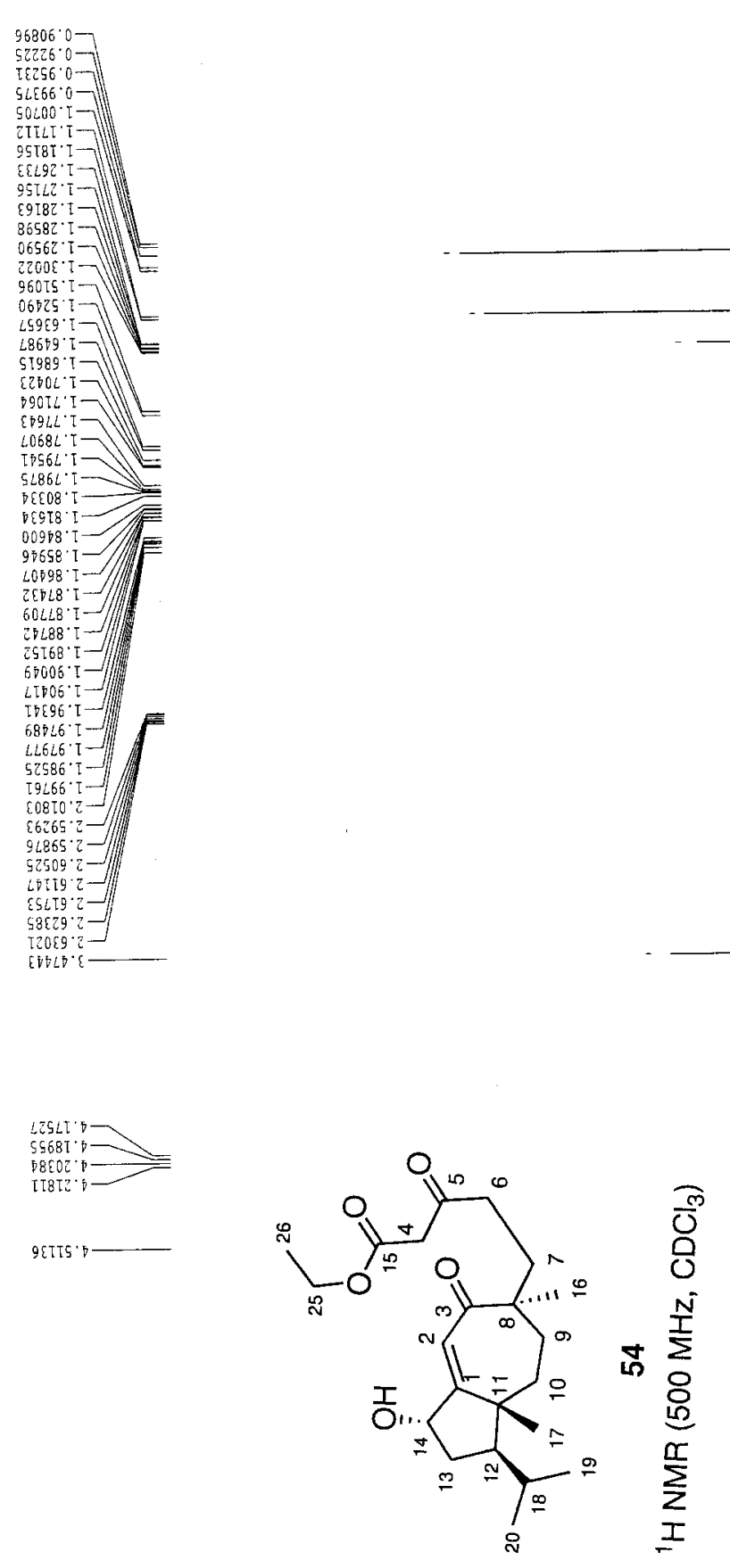

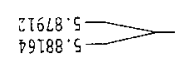

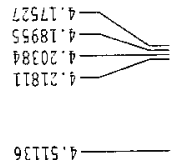

9etT5' 

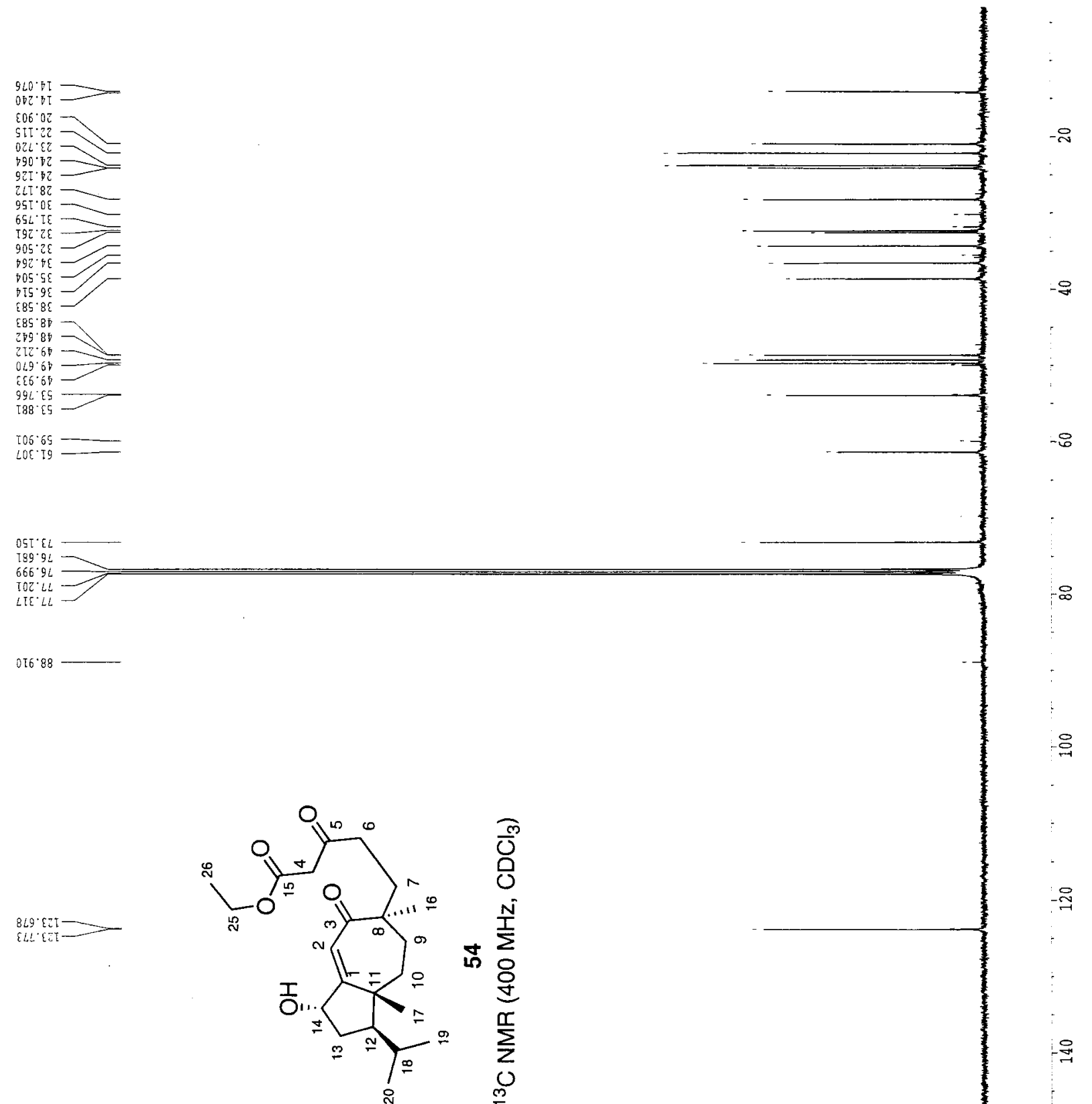

$68 L .991=$
$562.291=$

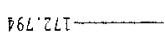

$\angle 50.6 L 1 \ldots$

90528 


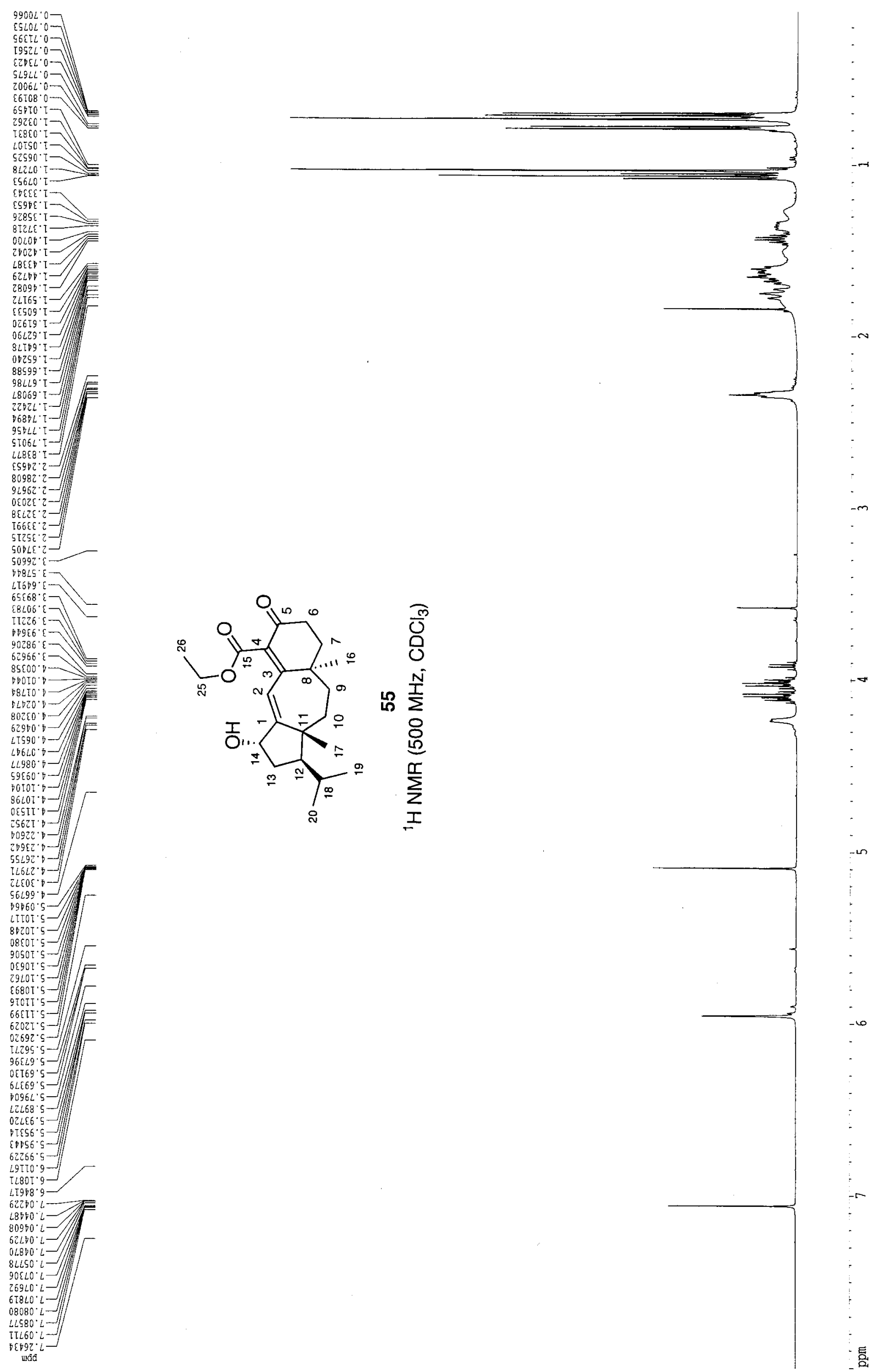



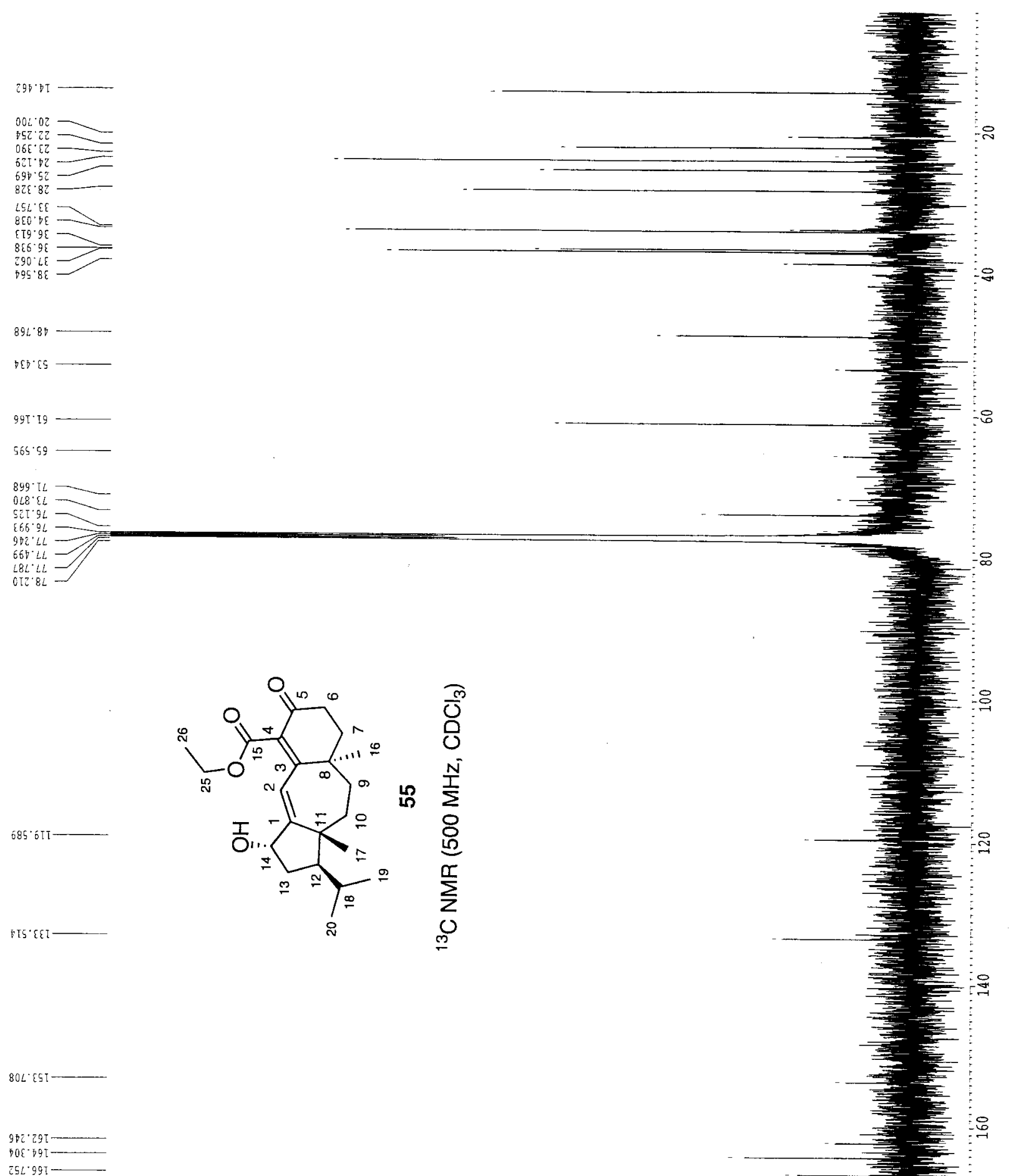

¿5L.99 -

$$
\begin{aligned}
& \text { 잉 } \\
& \text { N } \\
& \text { 员 } \\
& \text { 过 }
\end{aligned}
$$




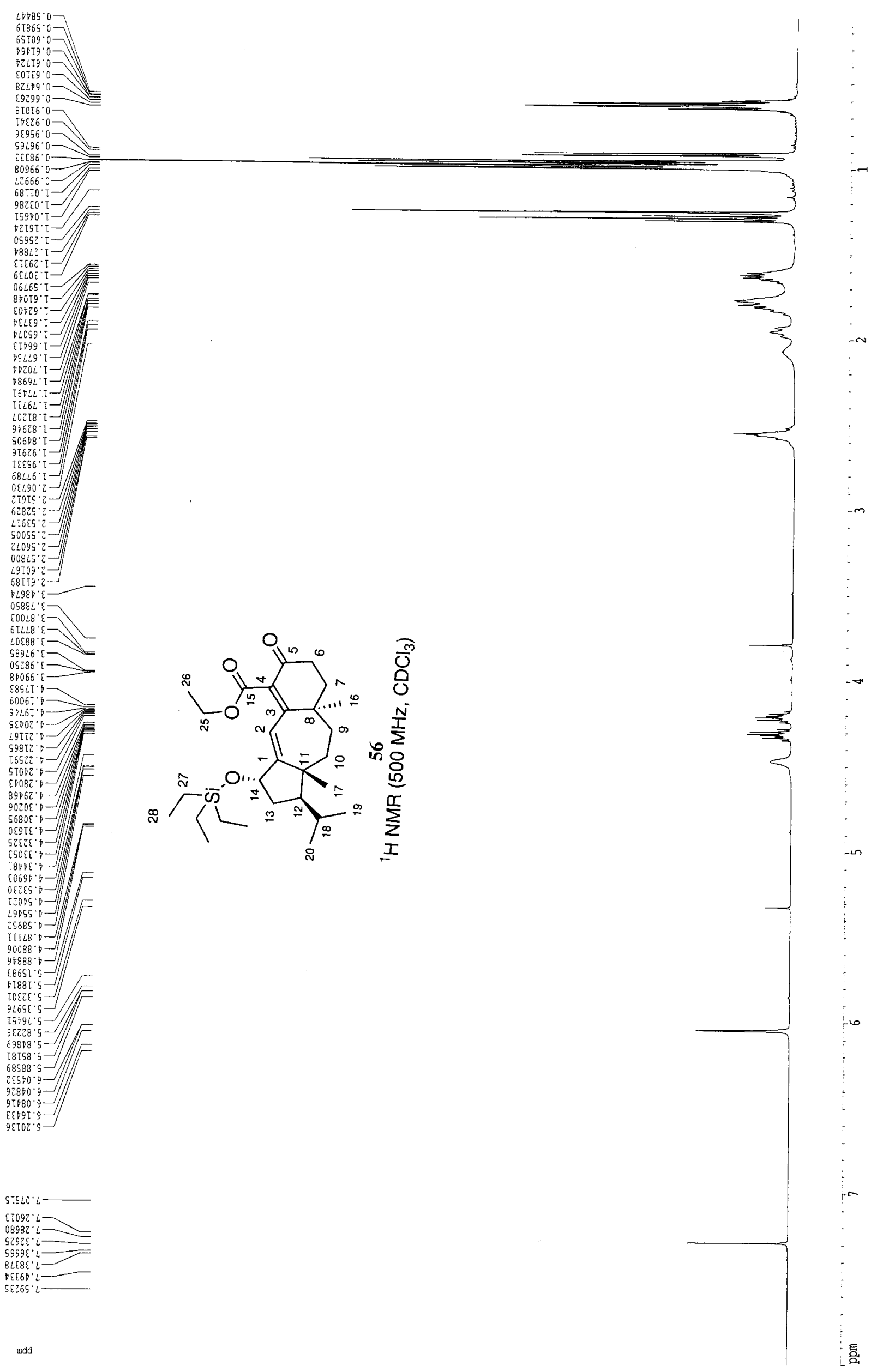




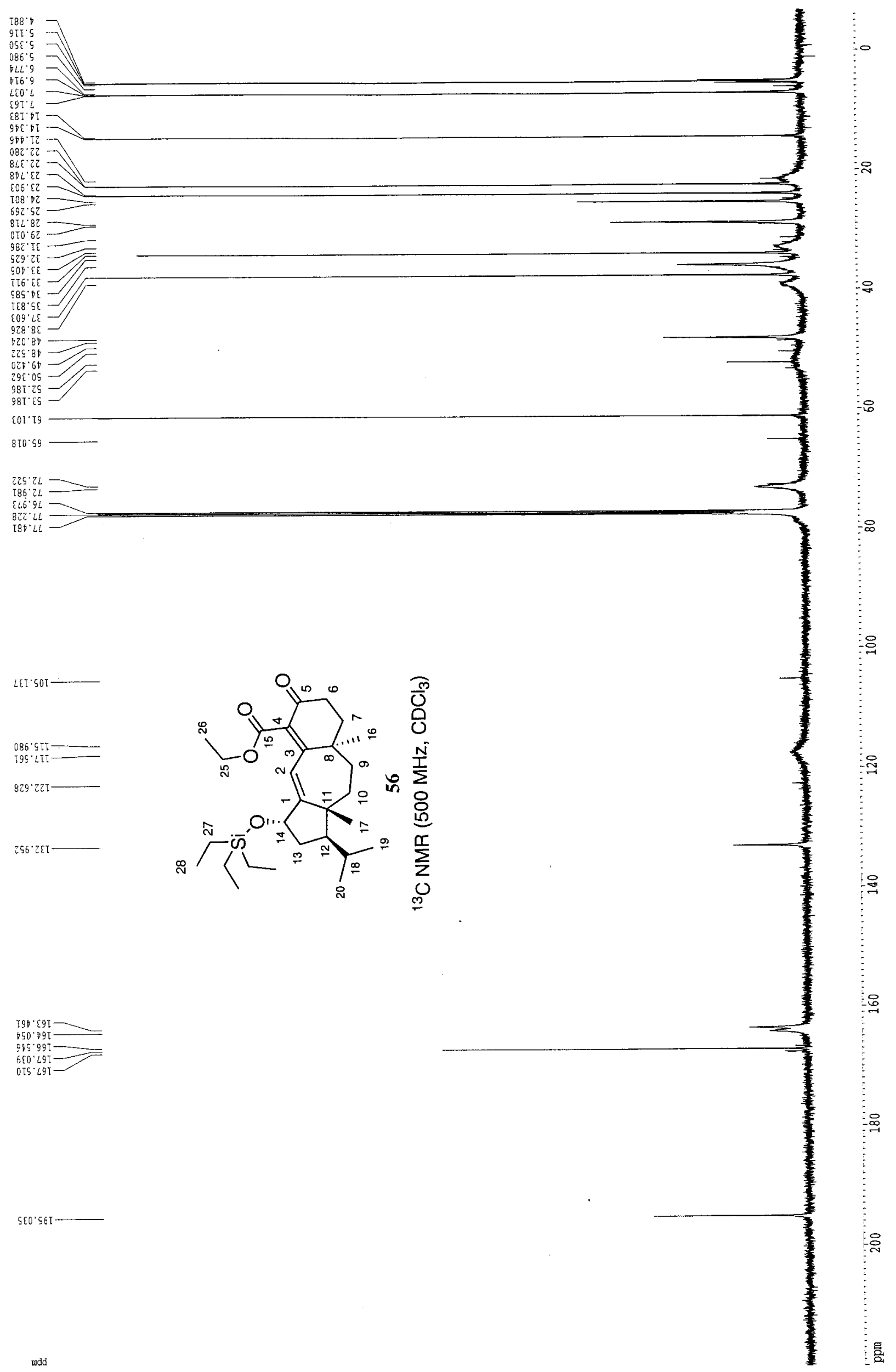



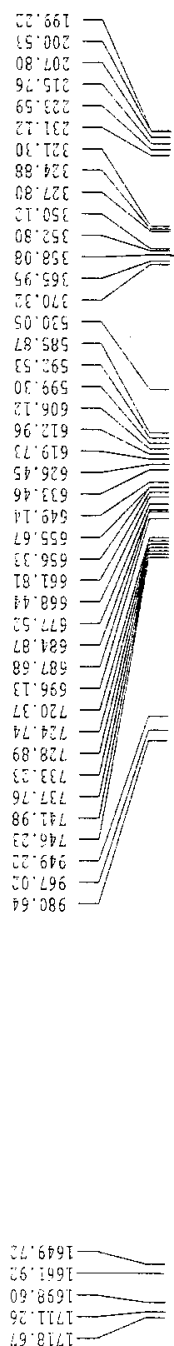

$40^{\circ} 5$ S

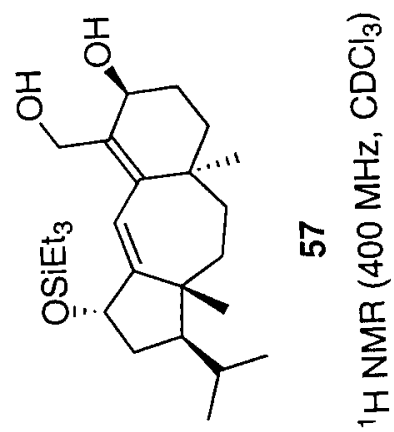

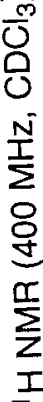

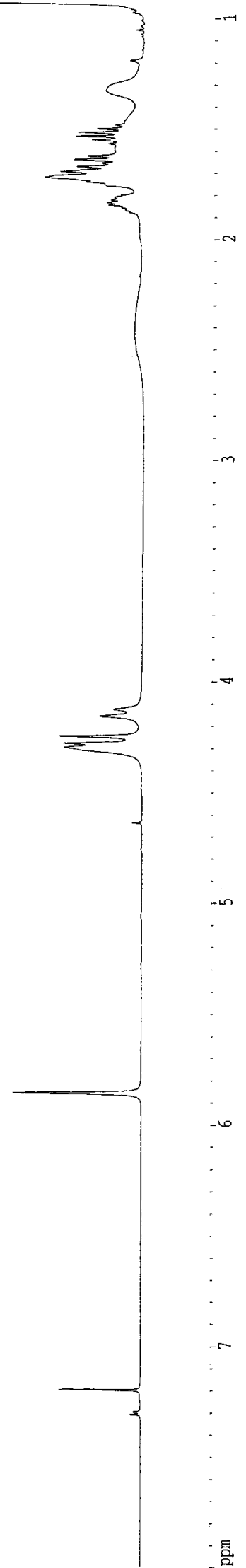



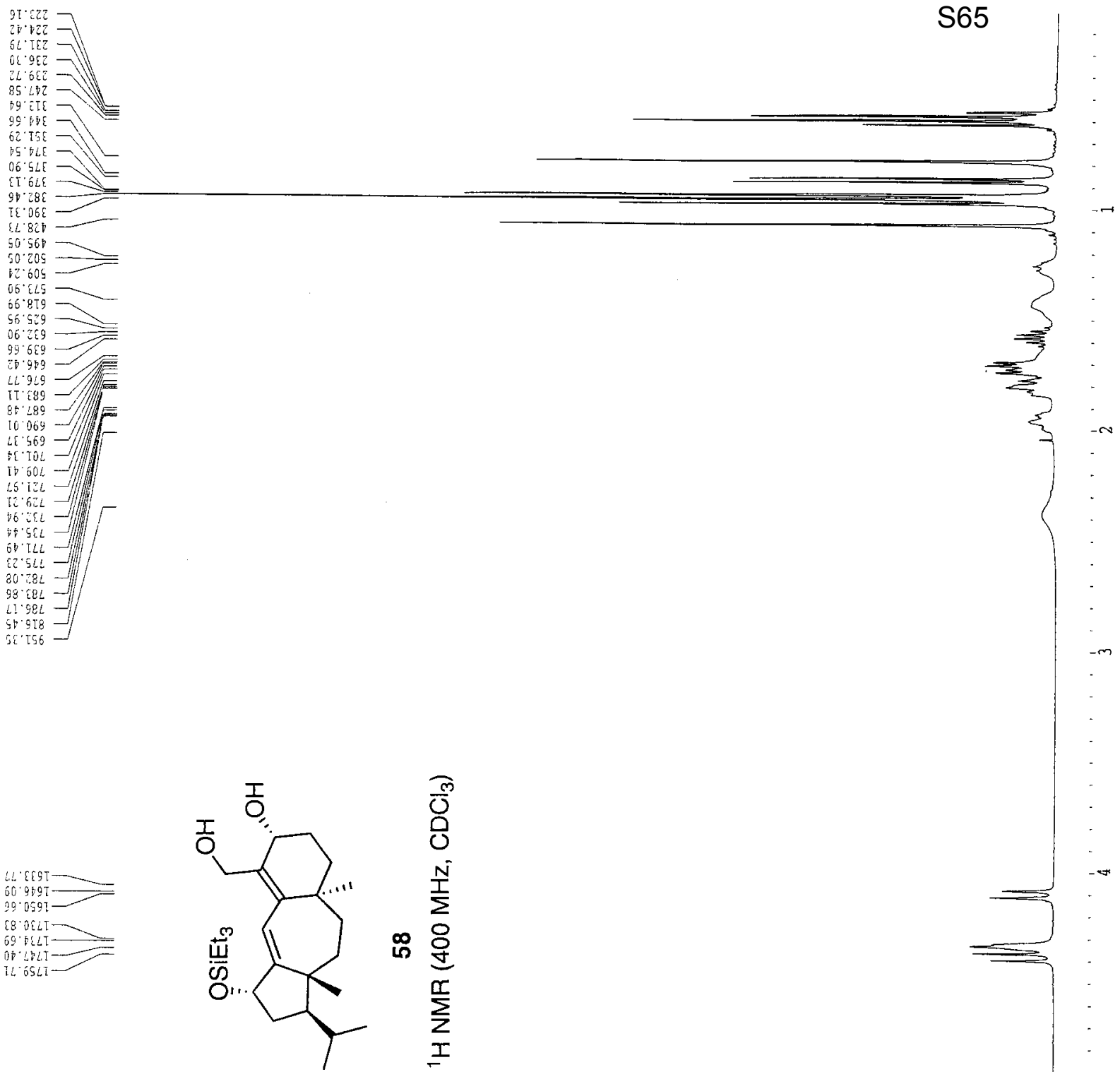

$69+40 t-\ldots$ 


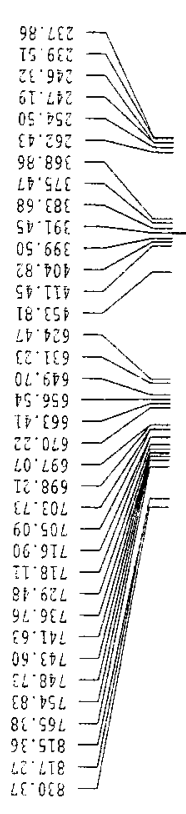

S66
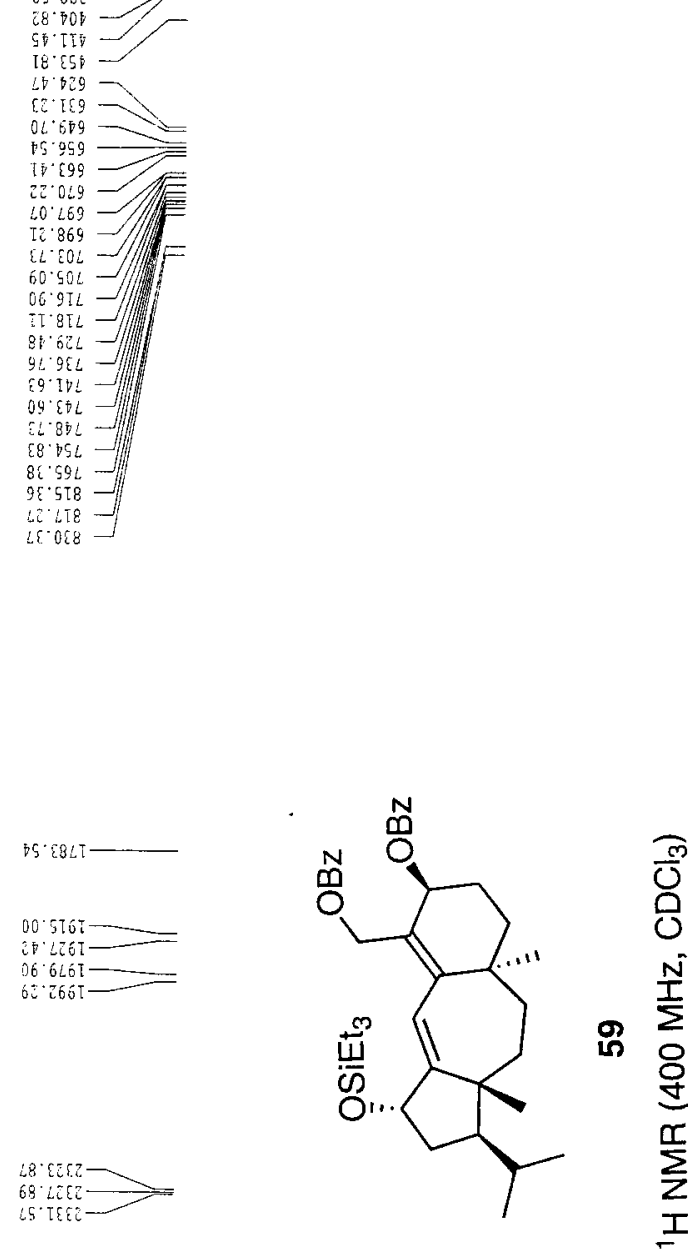

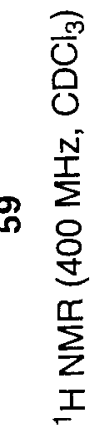

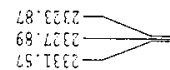

$88.65 k-$

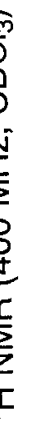
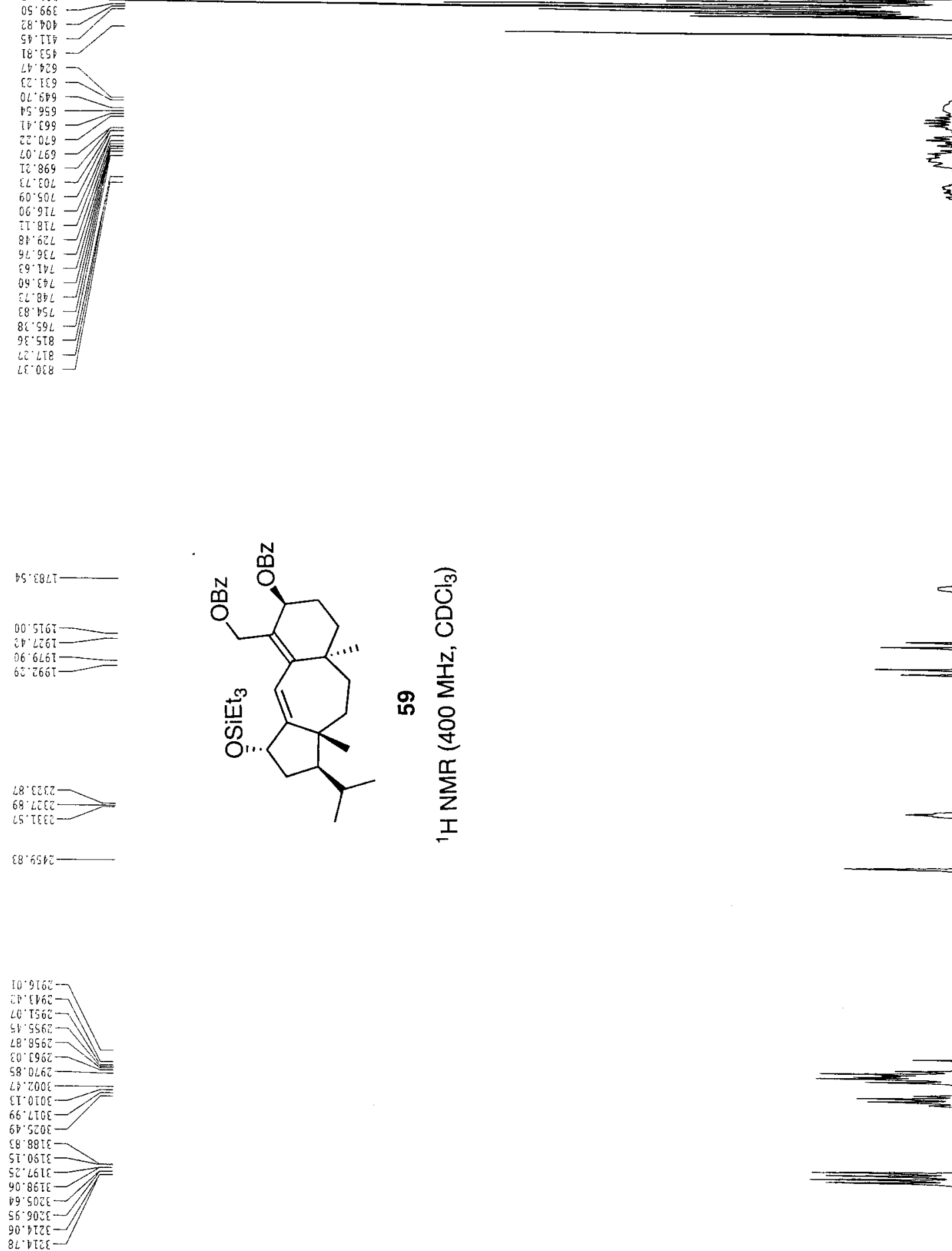


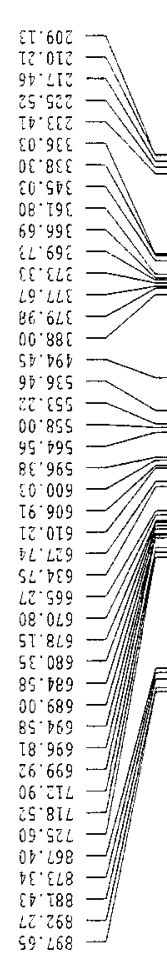

$512591-$

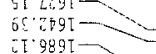

17. 6642

$5 \%$

$90^{\circ} \mathrm{LELT}$

$08.82 L T$
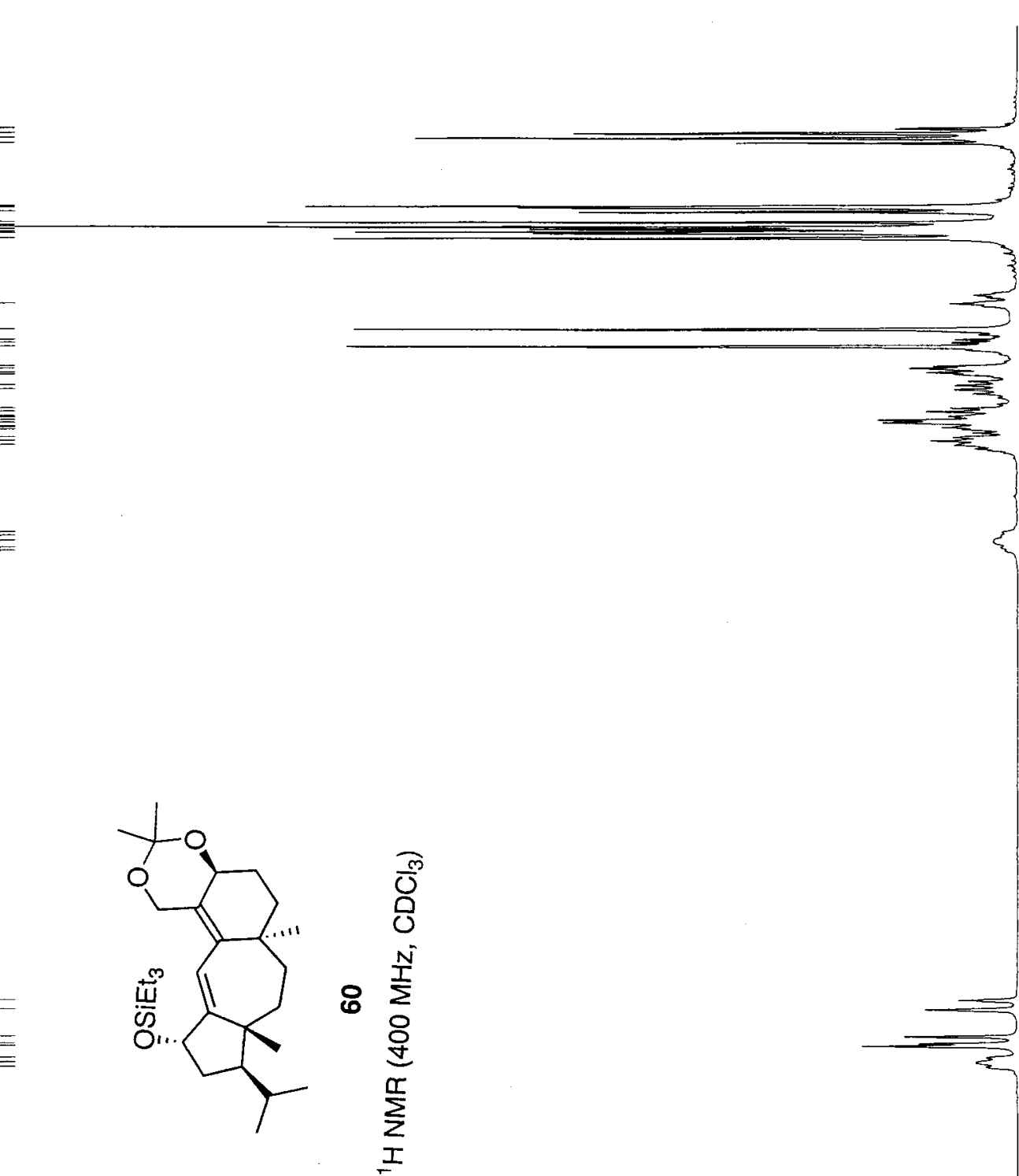

0
0
0
0
$N$
$\frac{1}{\Sigma}$
8
$\frac{1}{1}$
$\frac{1}{2}$
2

$24 \cdot 6922$

$98 \cdot 9682$ 


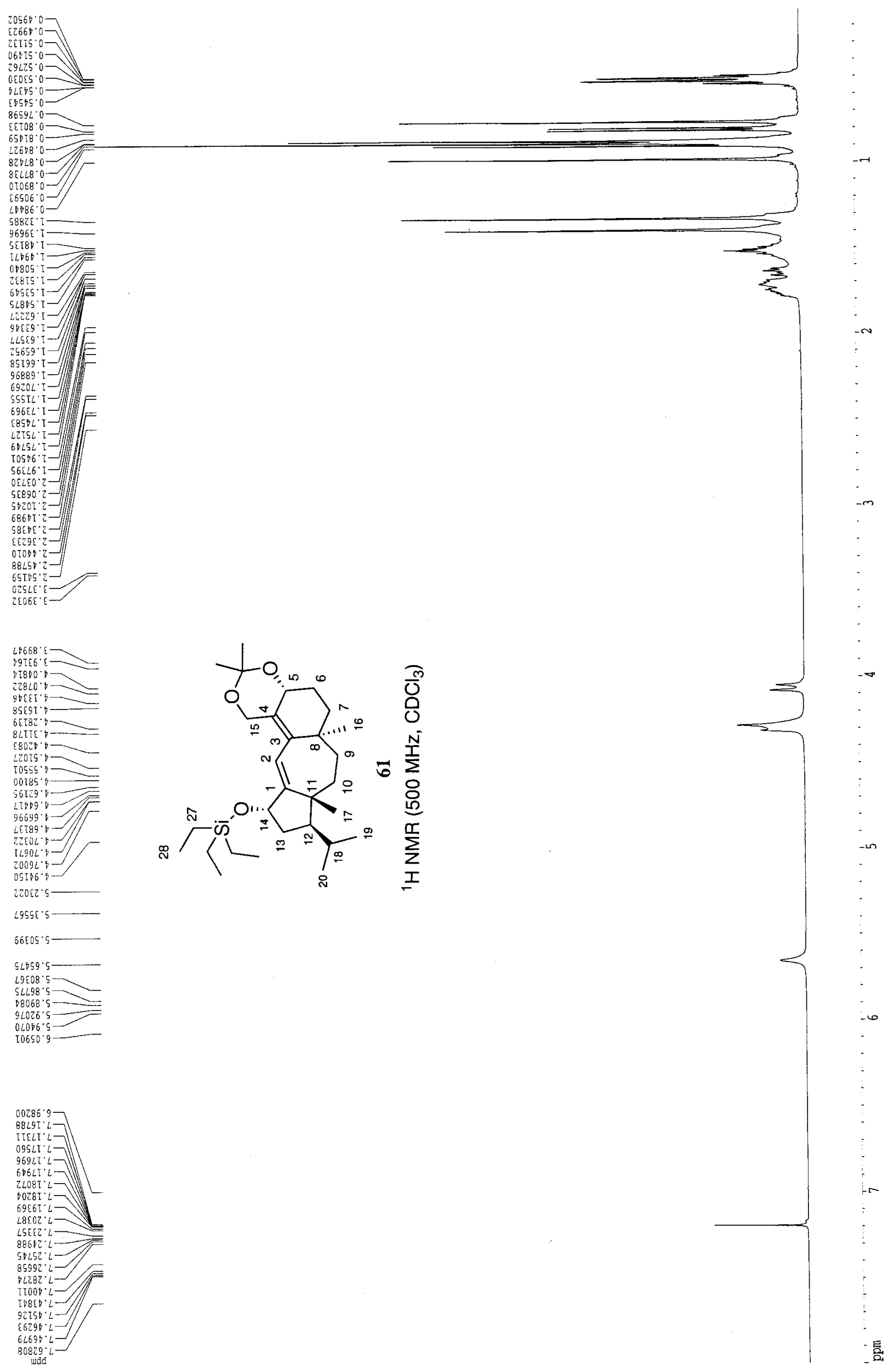




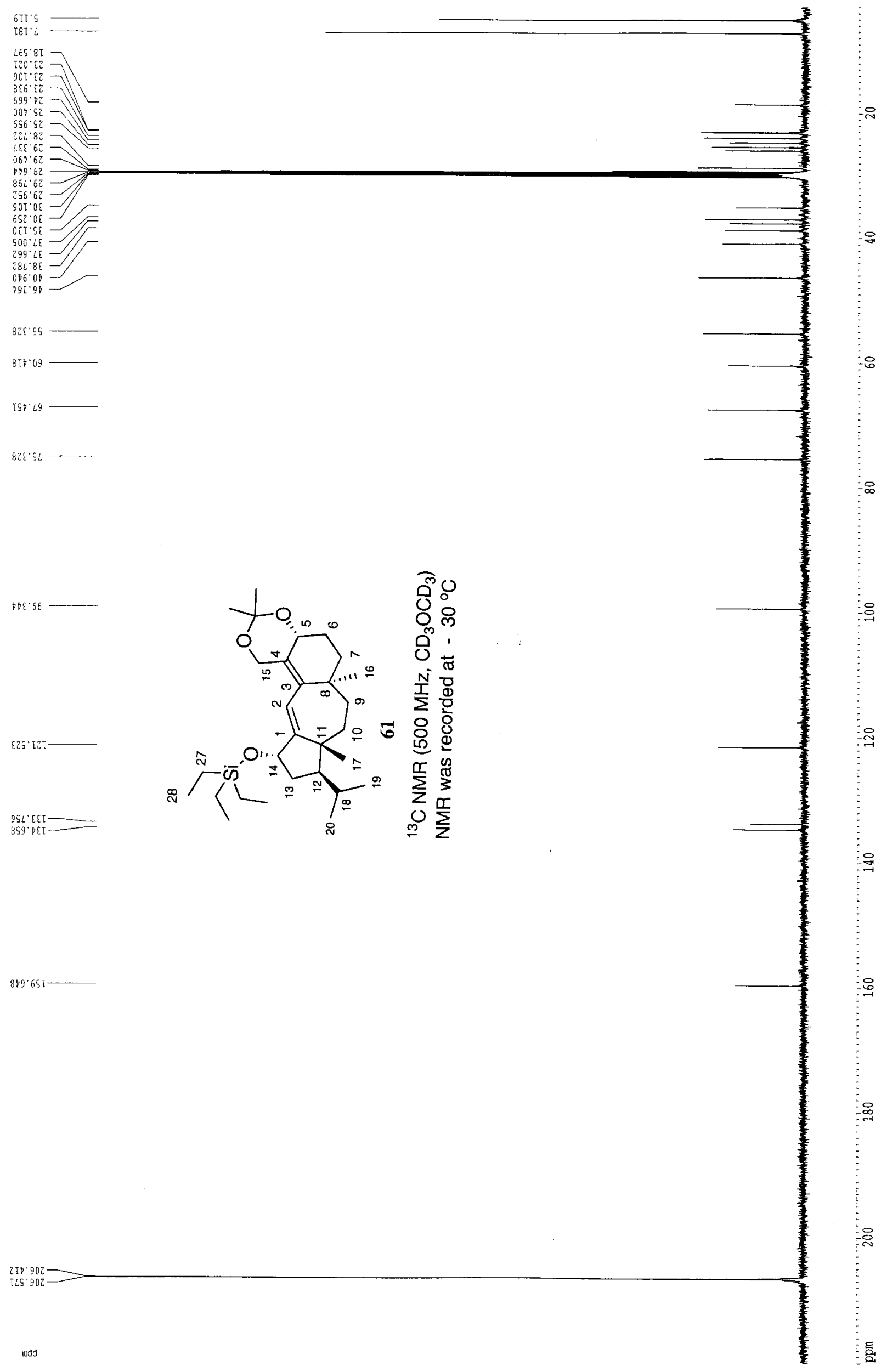




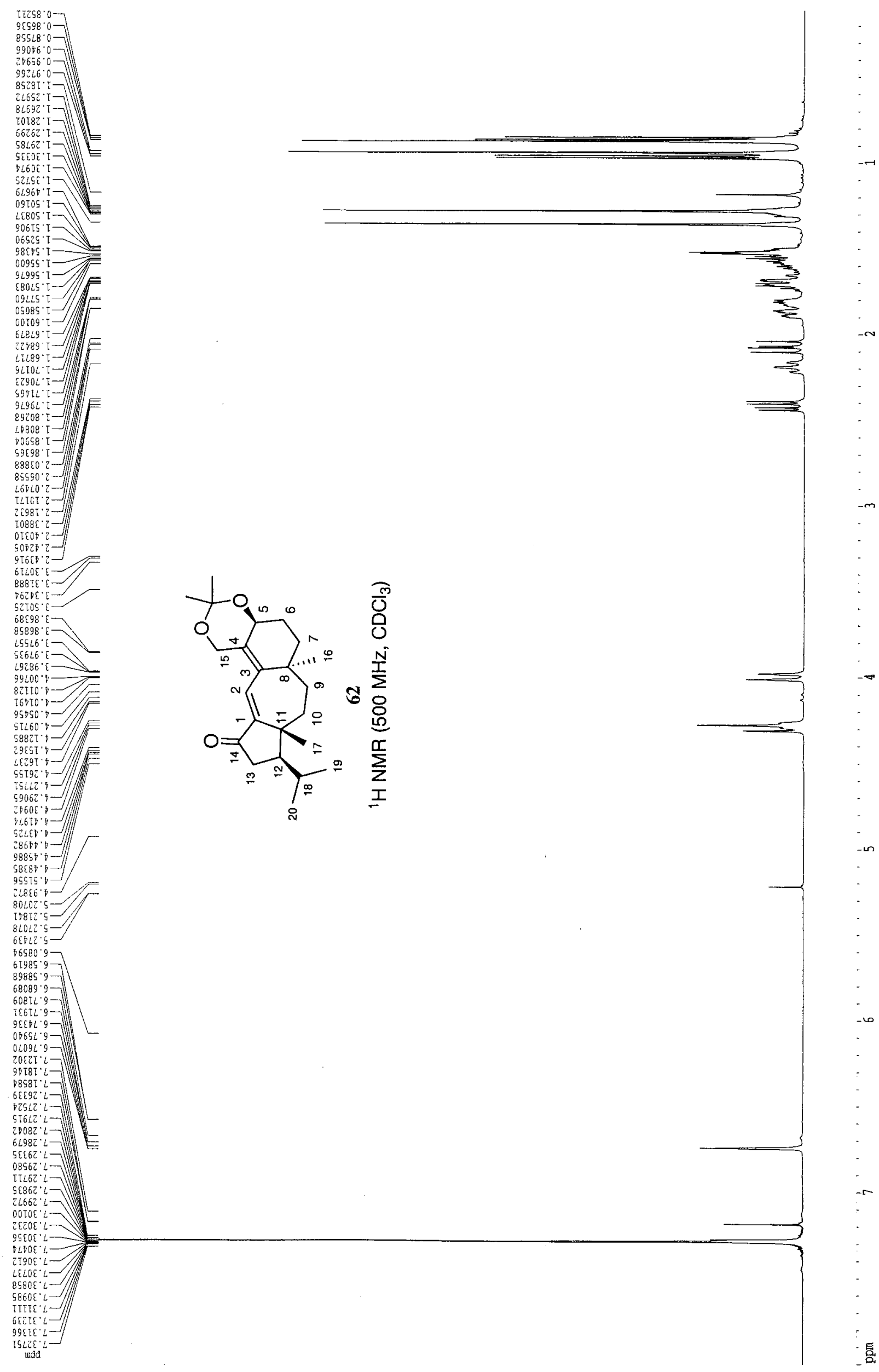




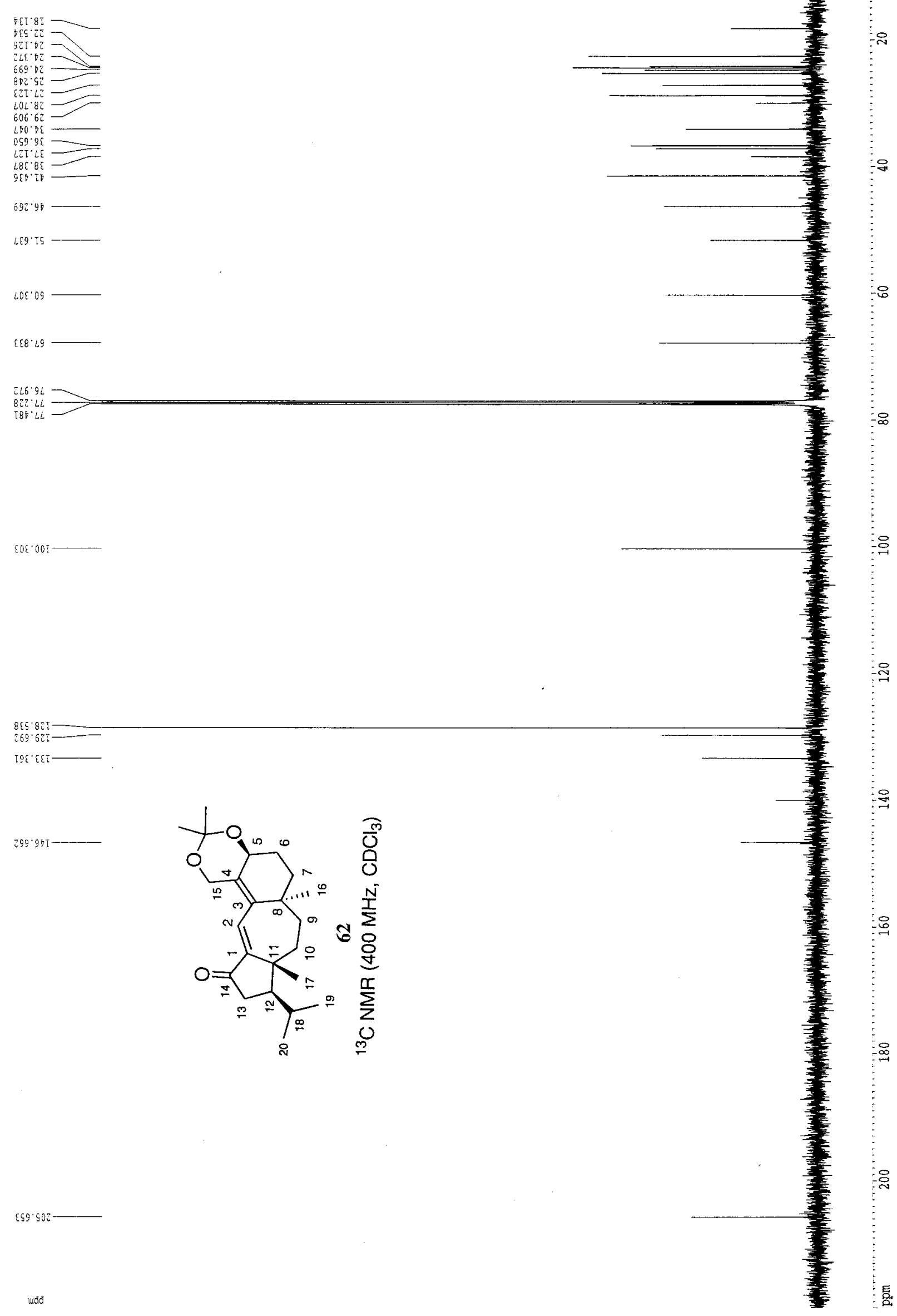



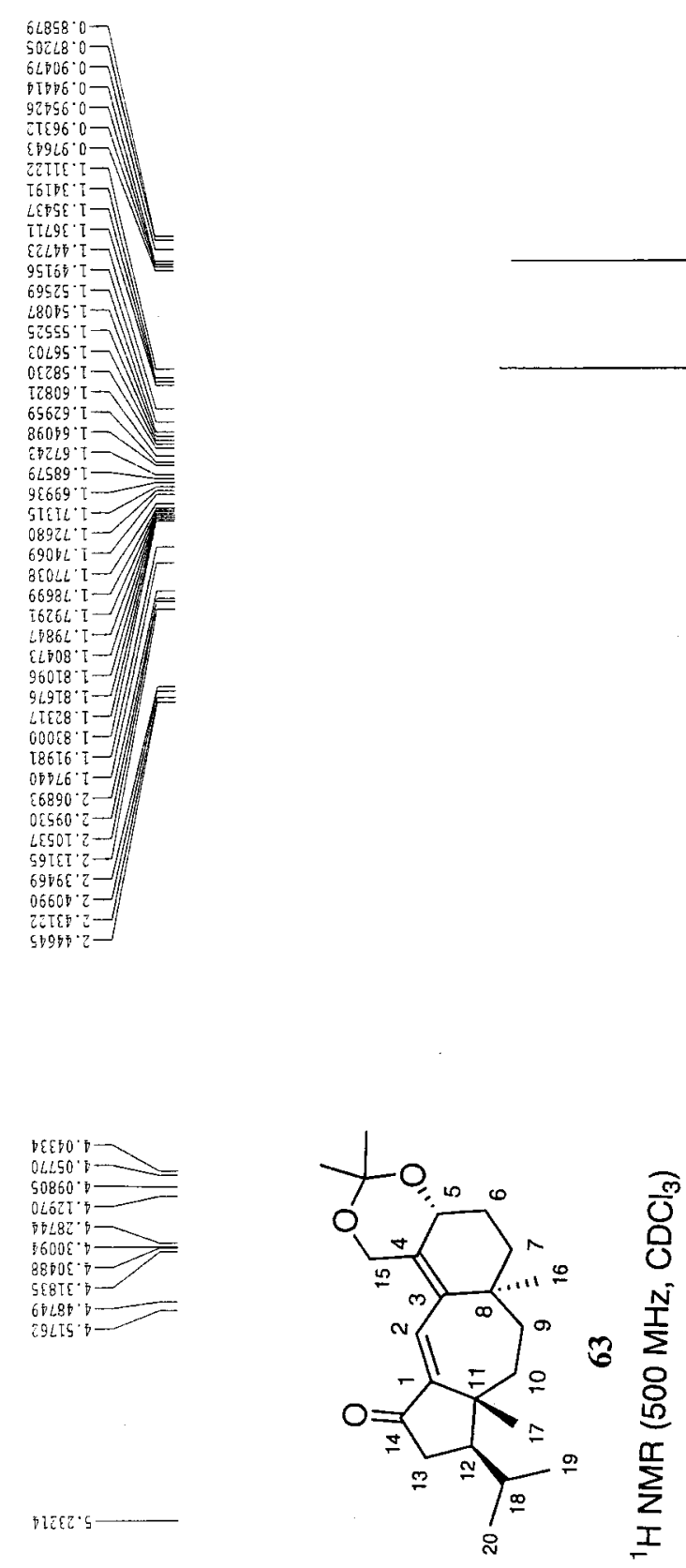

$72789 \cdot 9$

$29002: L$

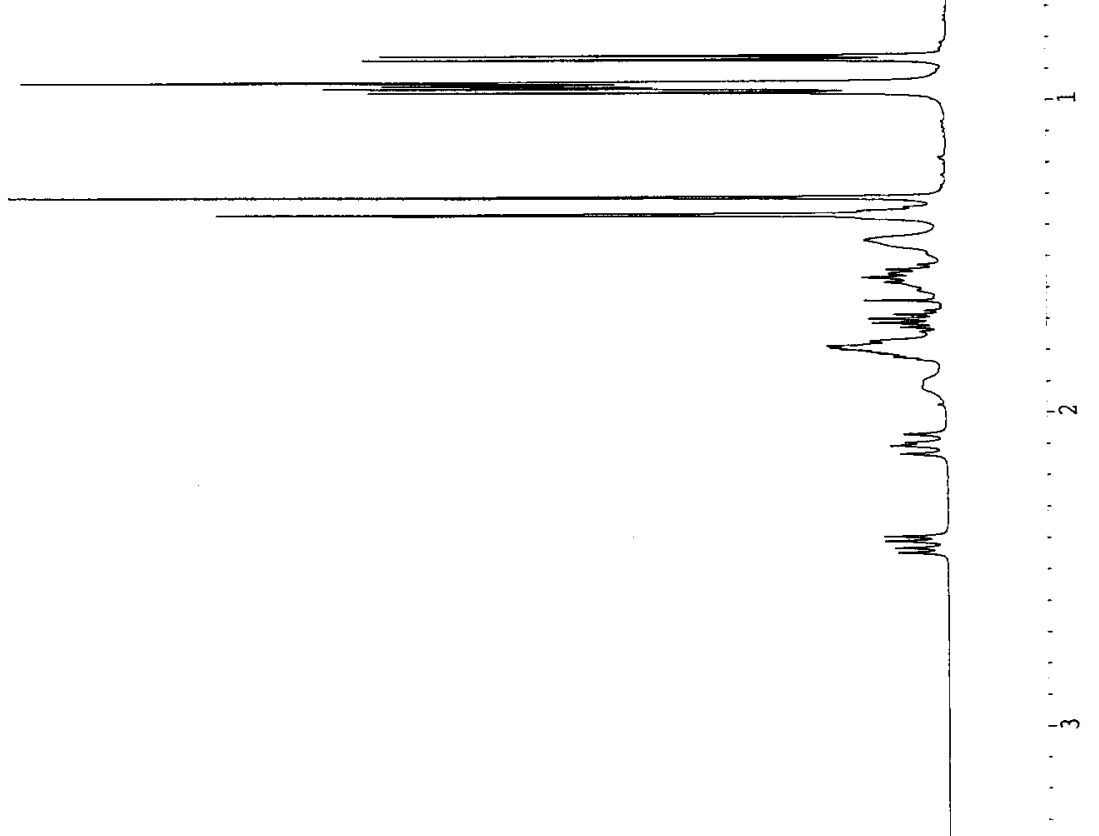

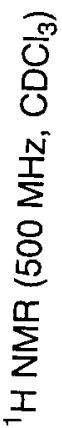




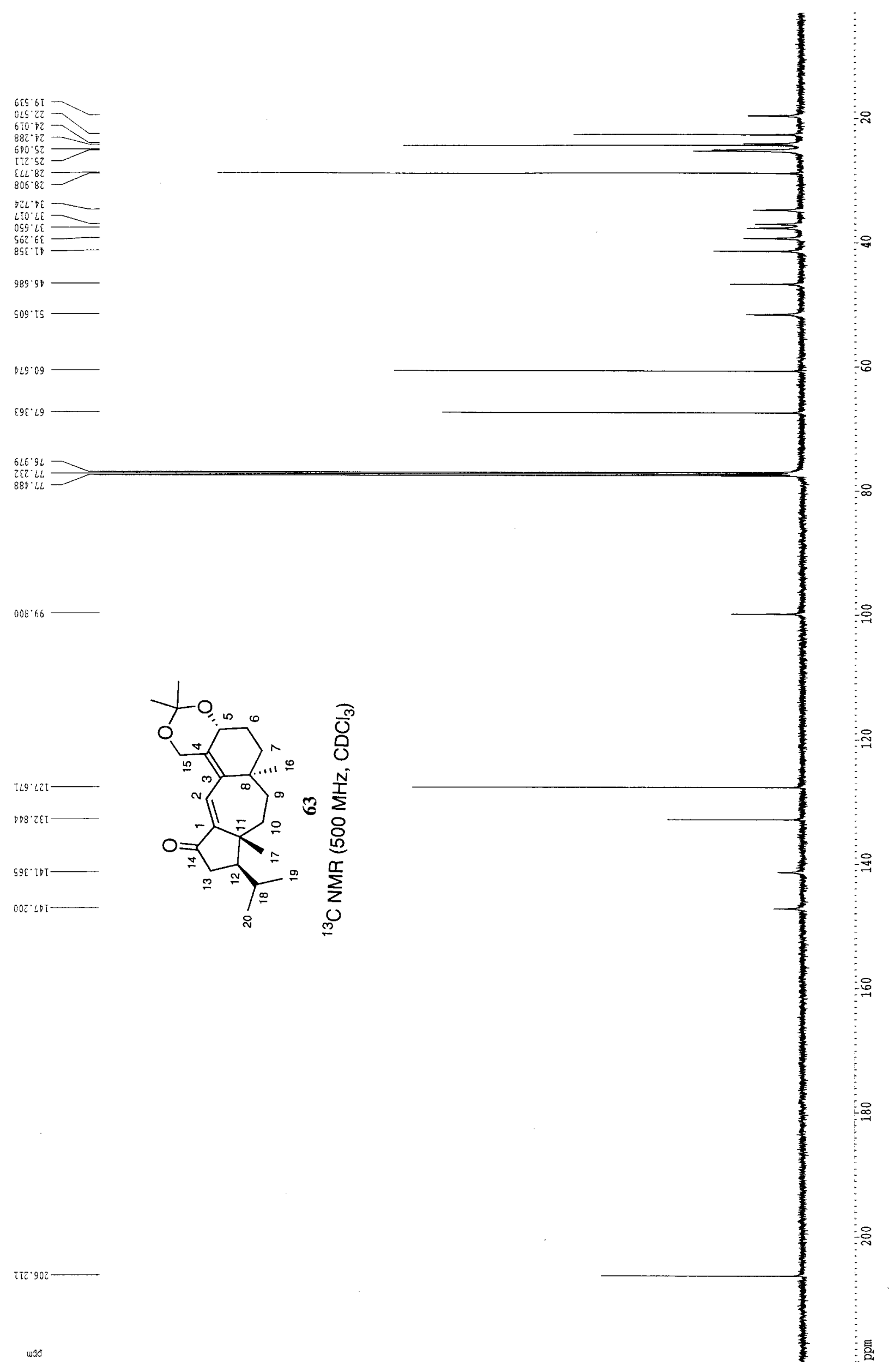




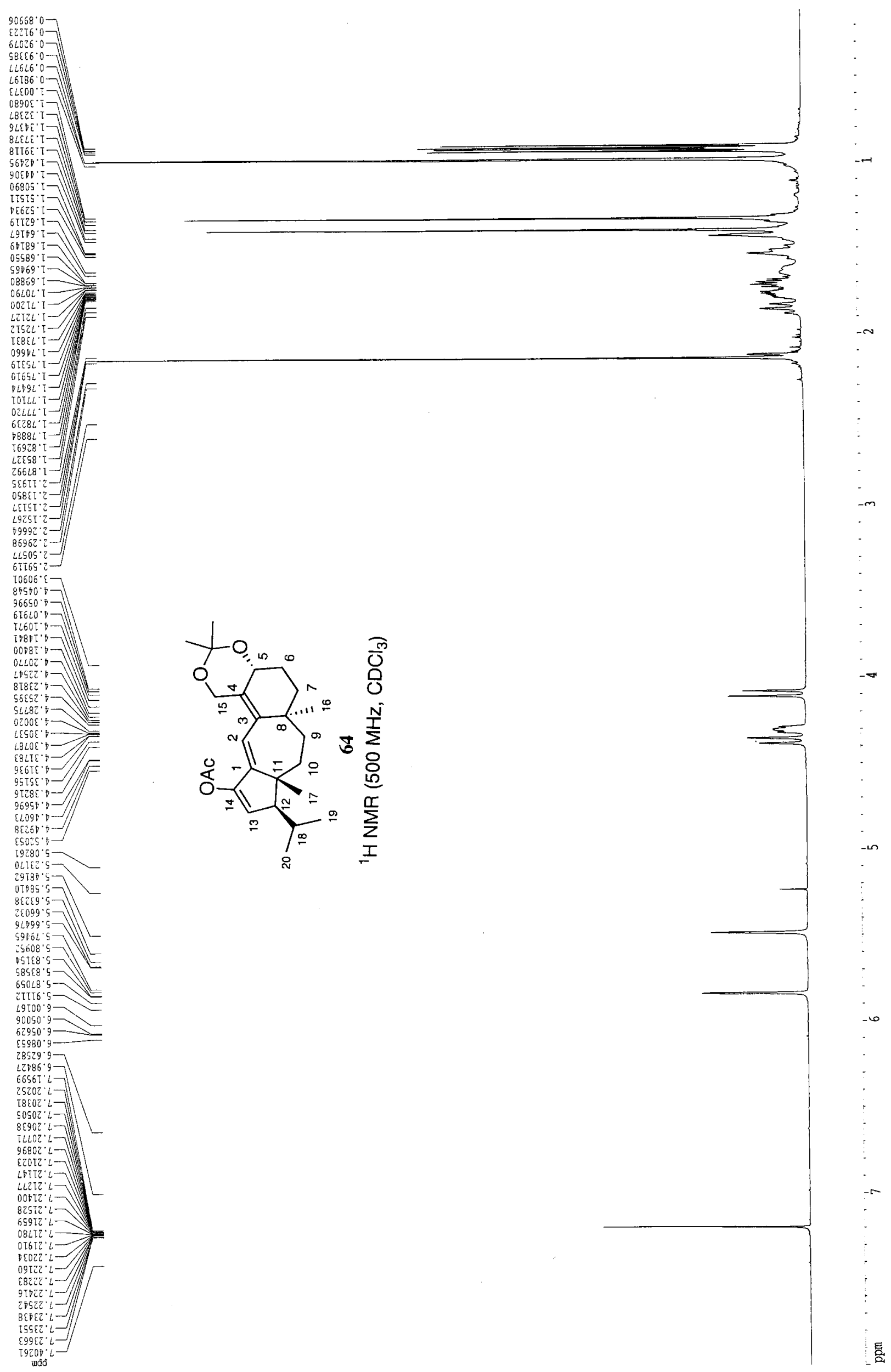




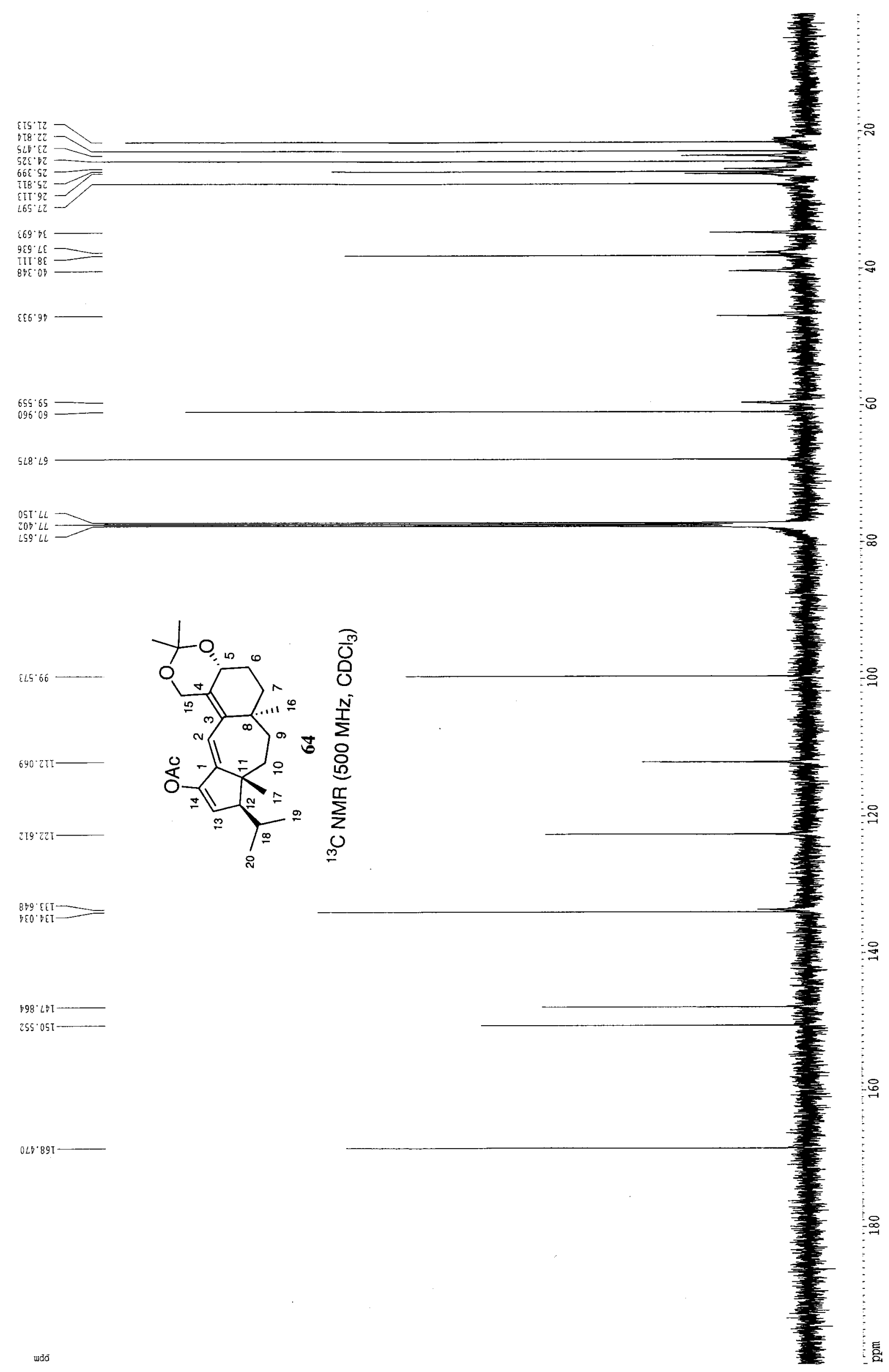




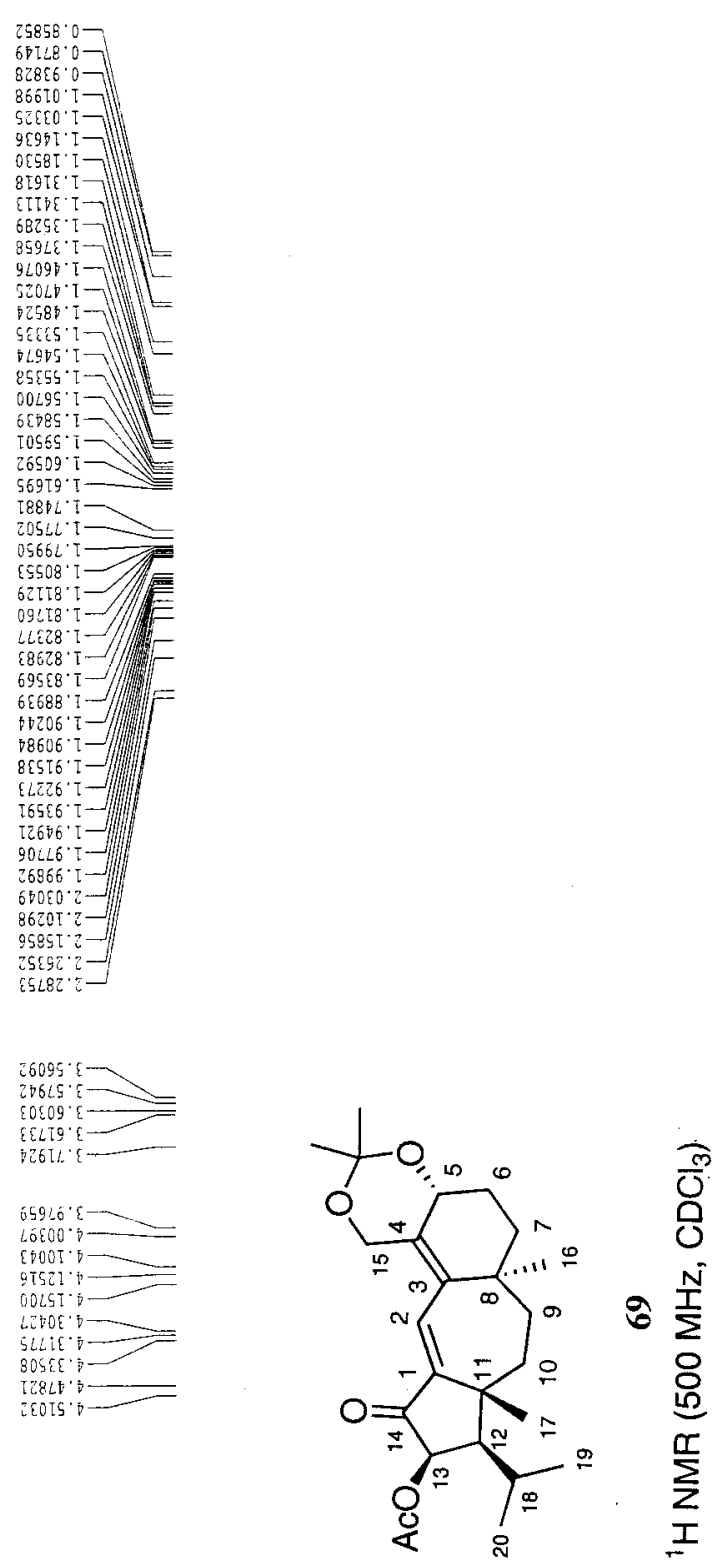

70:52: 5

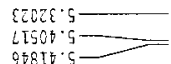

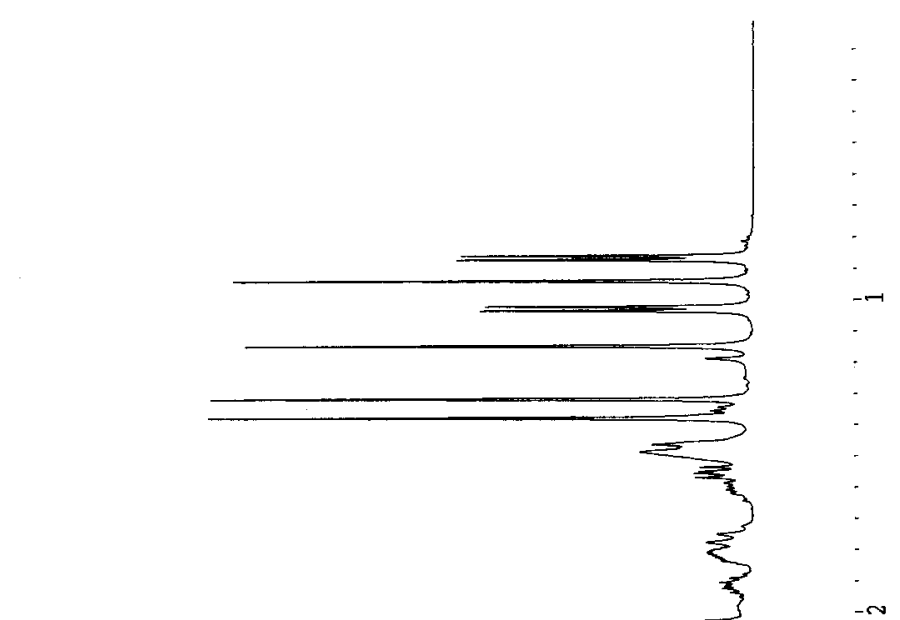

응

$\frac{1}{\Sigma}$

通

$\sum_{\substack{\mathbb{T} \\ I}}^{\mathbb{T}}$

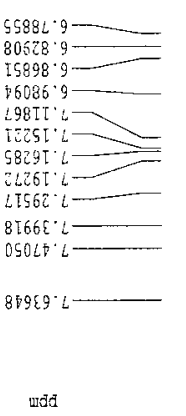




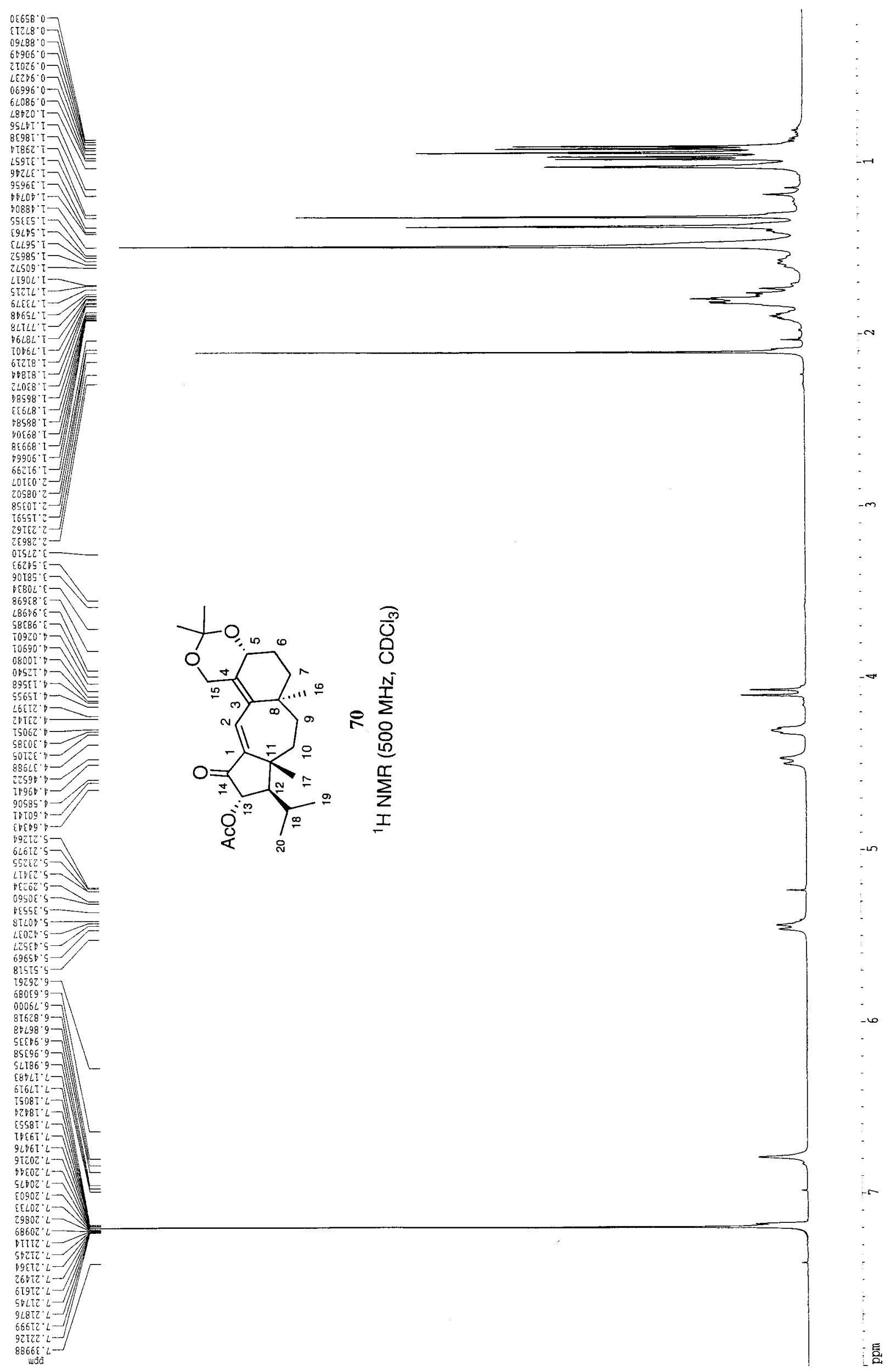




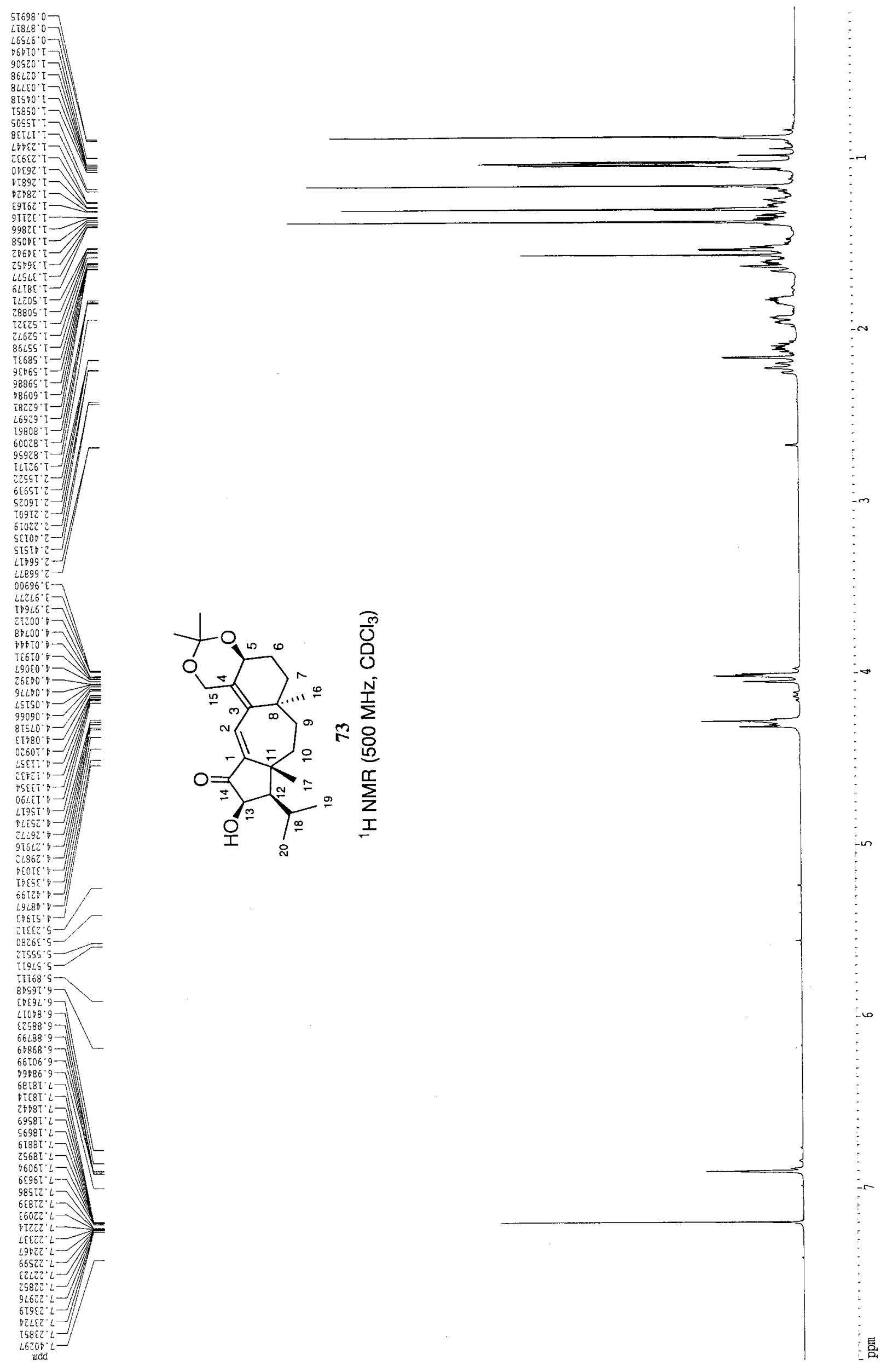




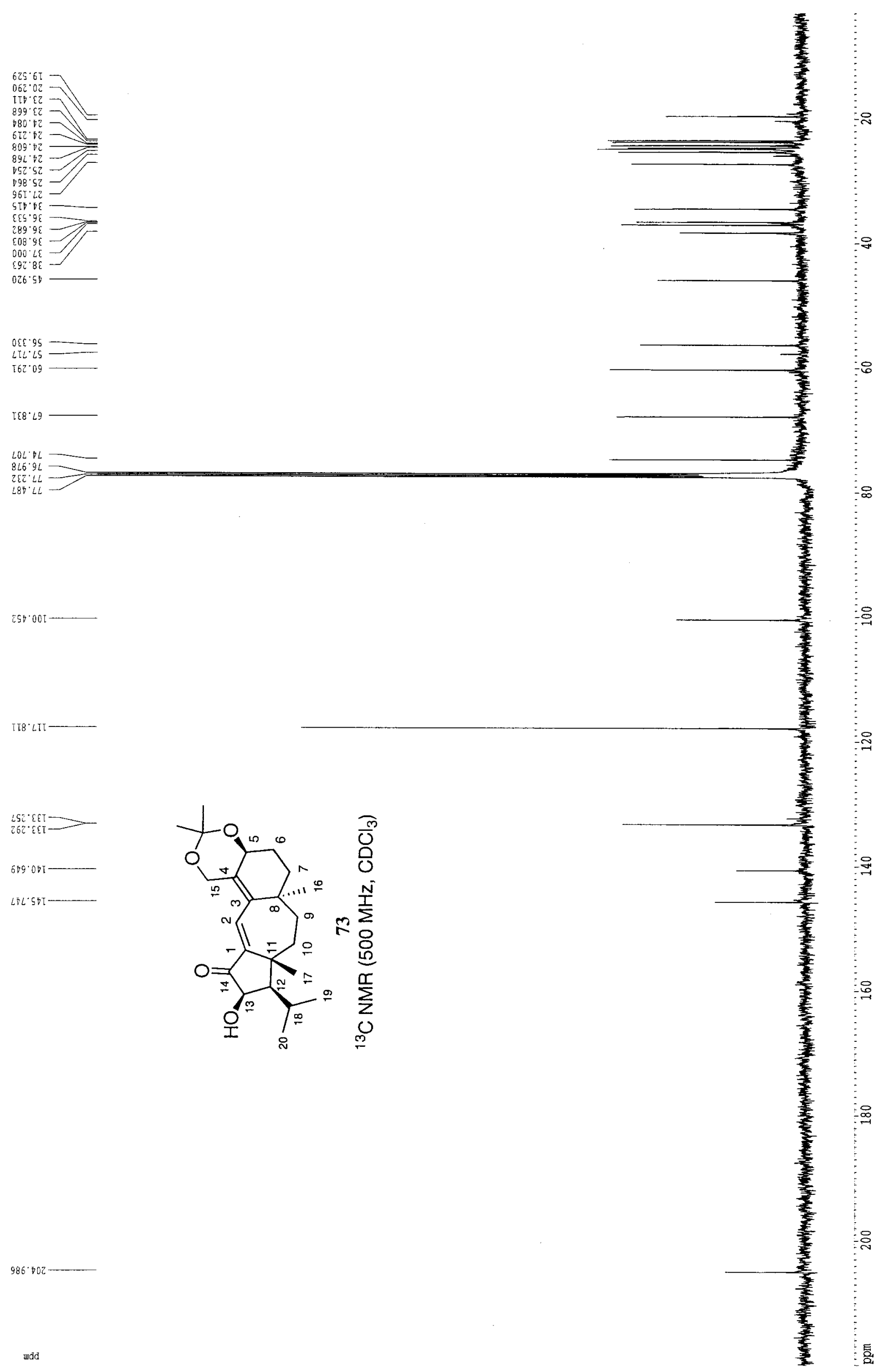




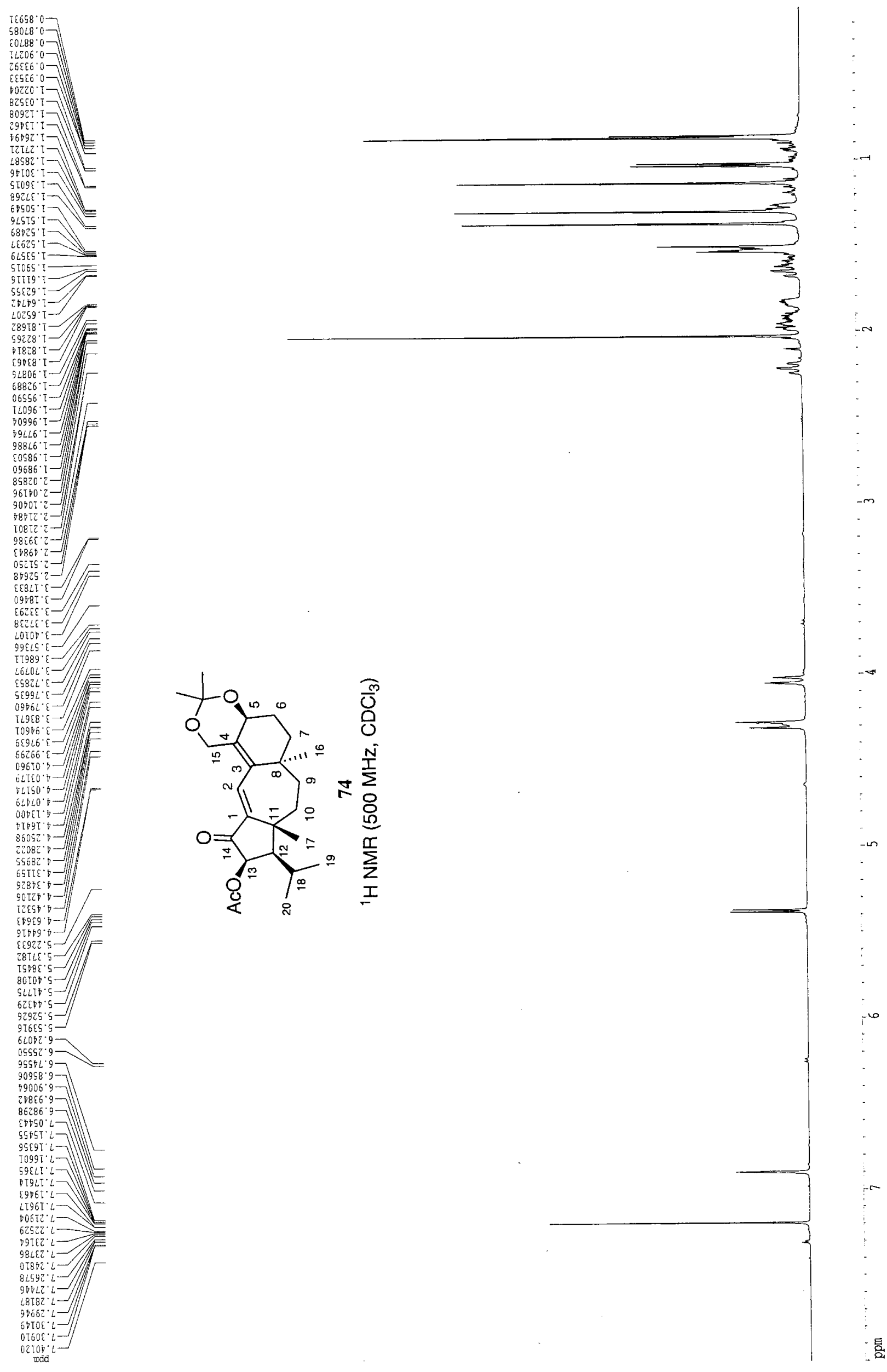



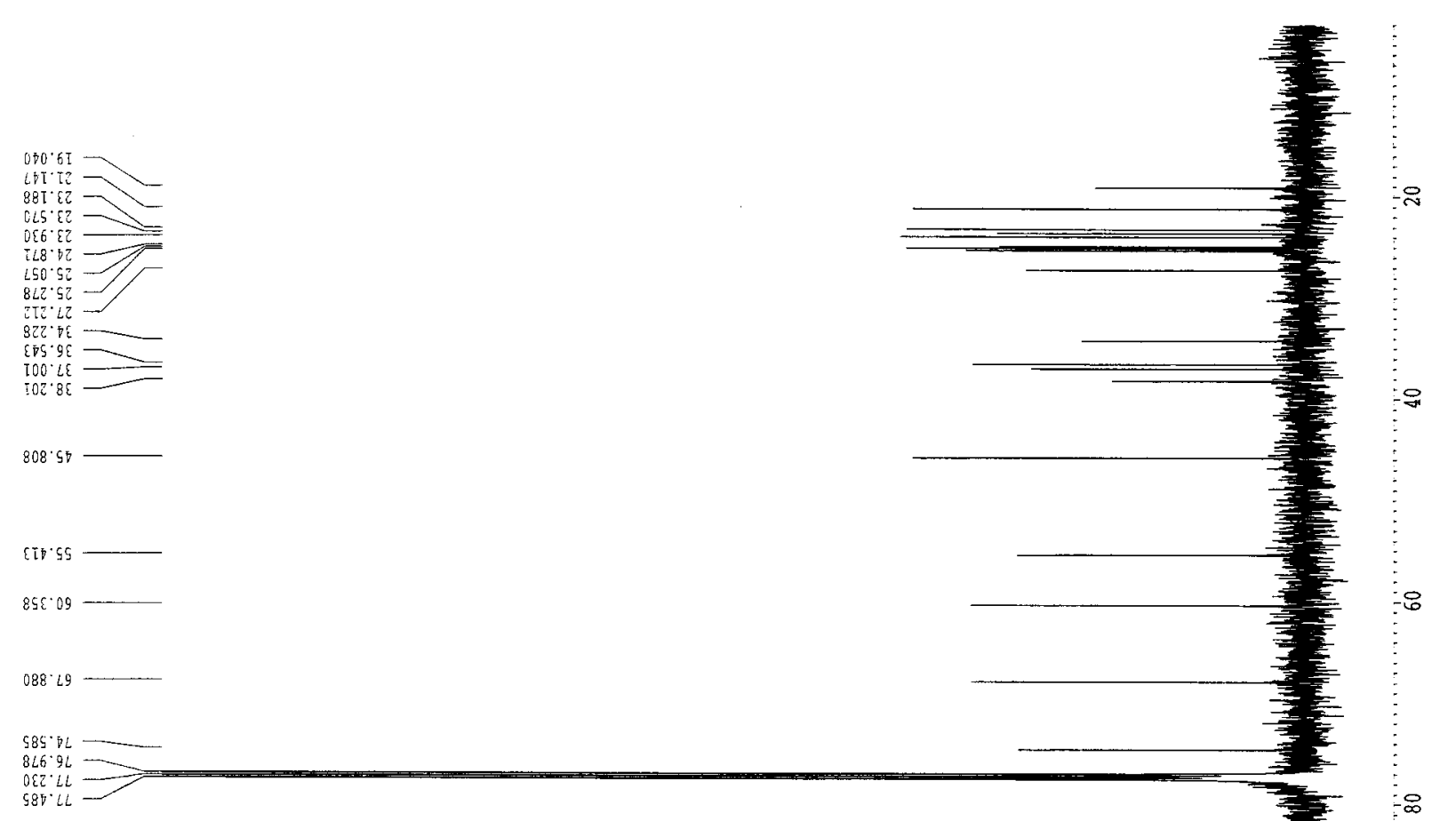

$098^{\circ} 001-$

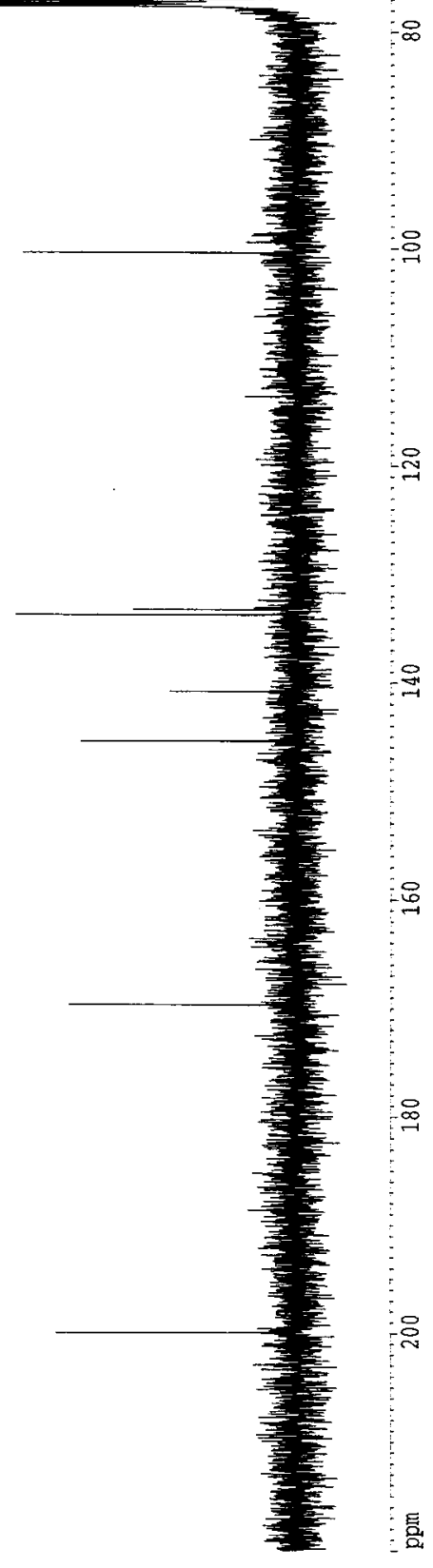




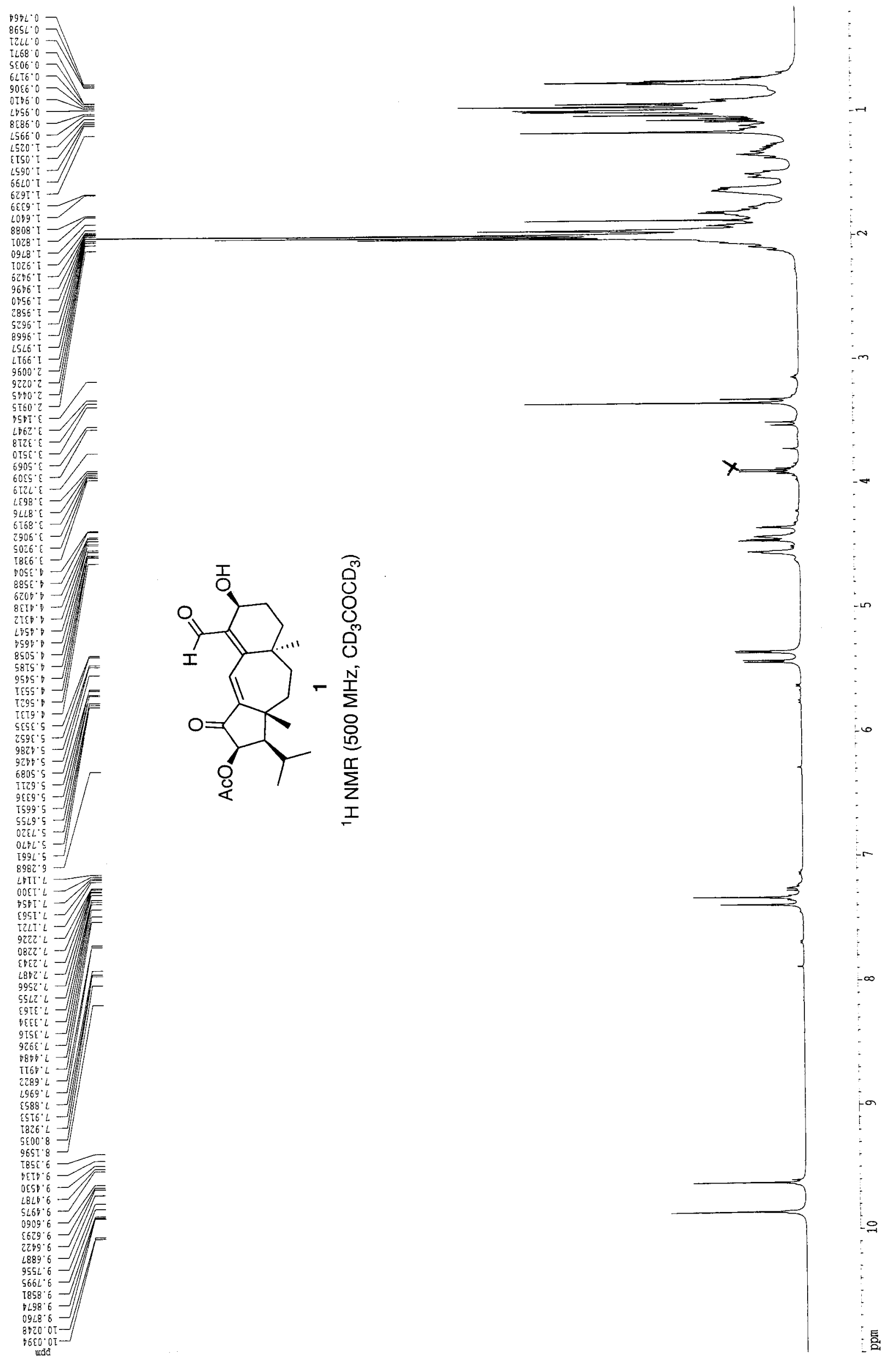




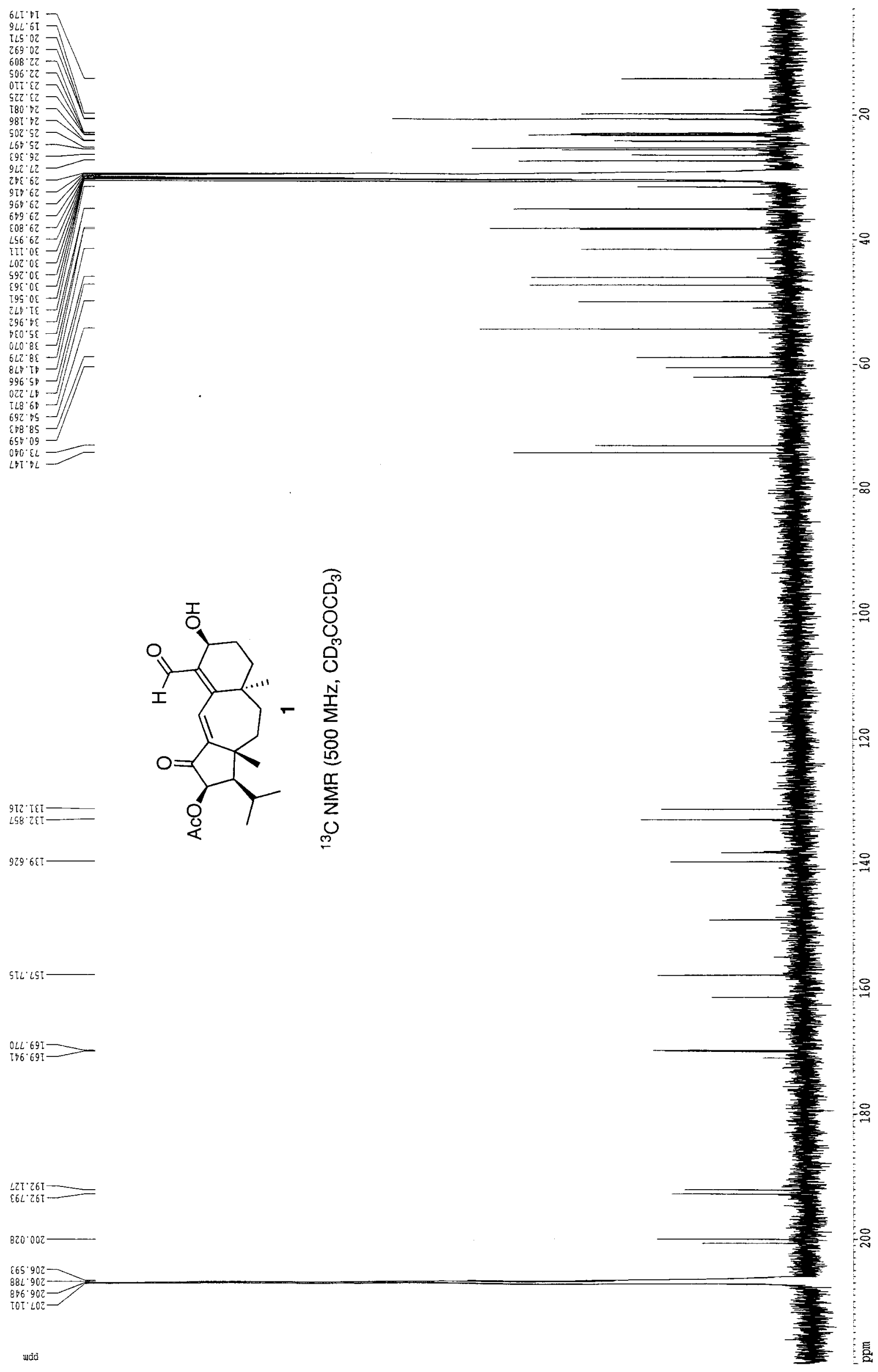




\section{Compound 100}
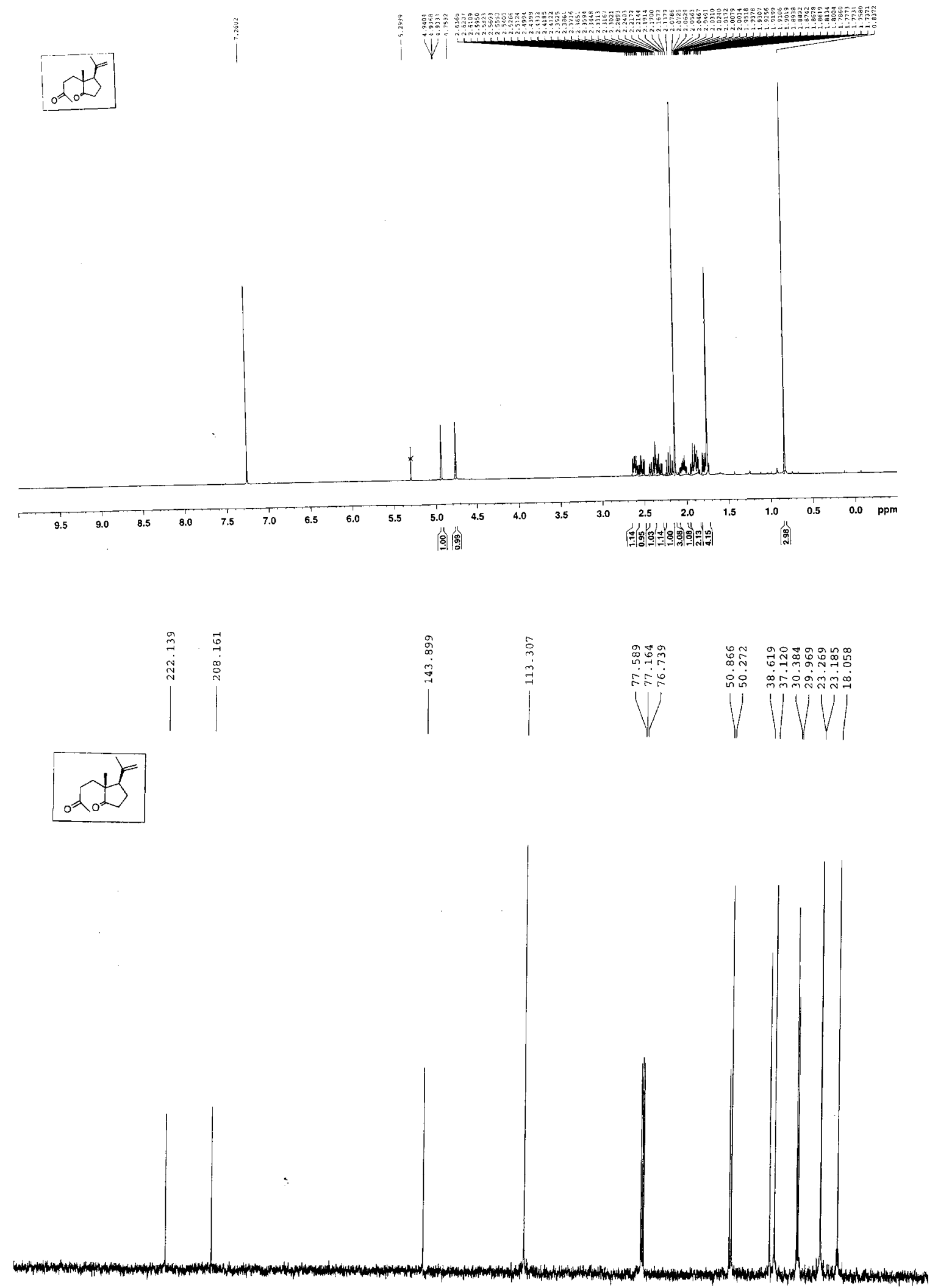

$\begin{array}{llllllllllllllllllllllllllll}260 & 250 & 240 & 230 & 220 & 210 & 200 & 190 & 180 & 170 & 160 & 150 & 140 & 130 & 120 & 110 & 100 & 90 & 80 & 70 & 60 & 50 & 40 & 30 & 20 & 10 & 0 & 0\end{array}$ 


\section{Compound 93}
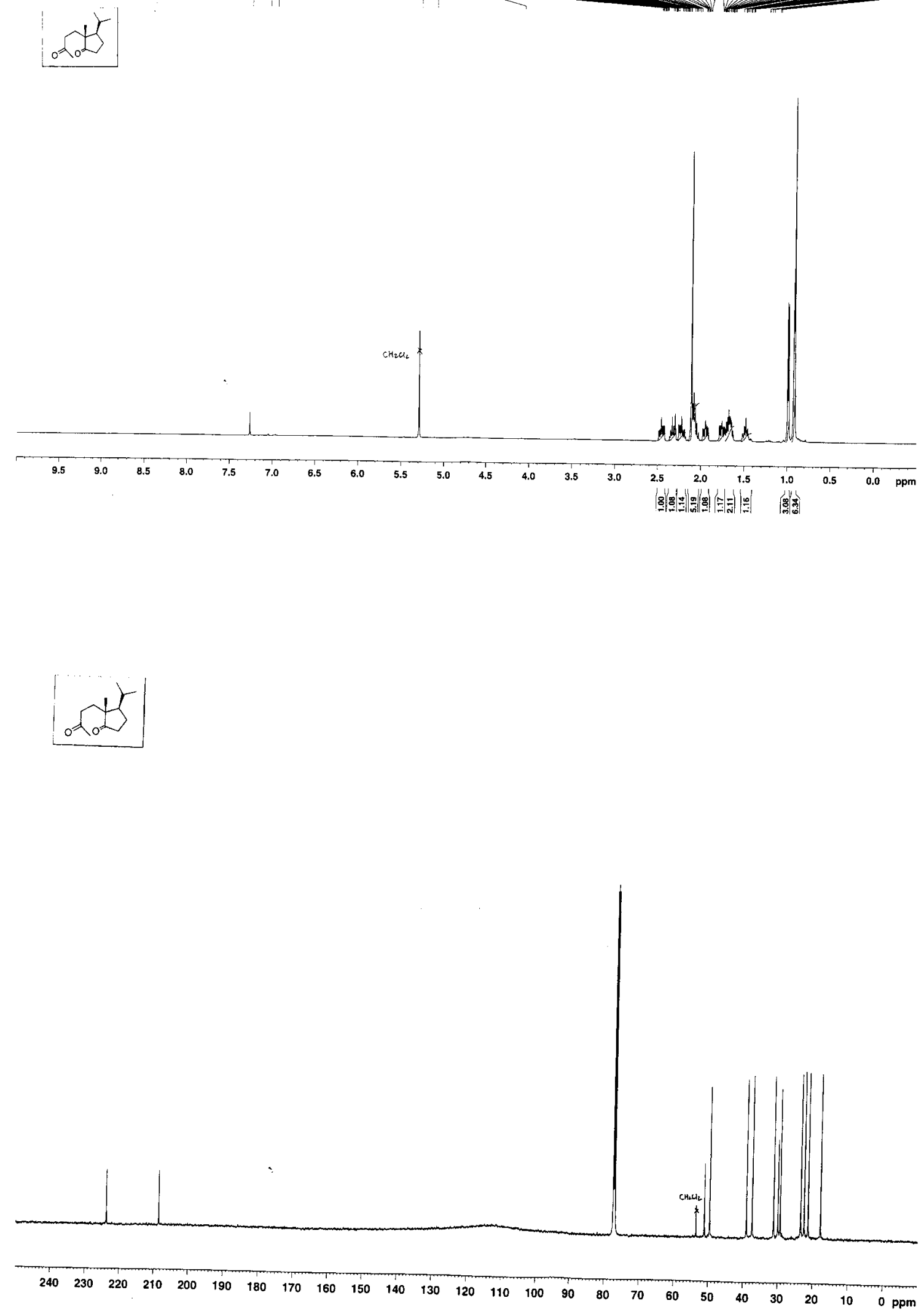


\section{Compound 94}
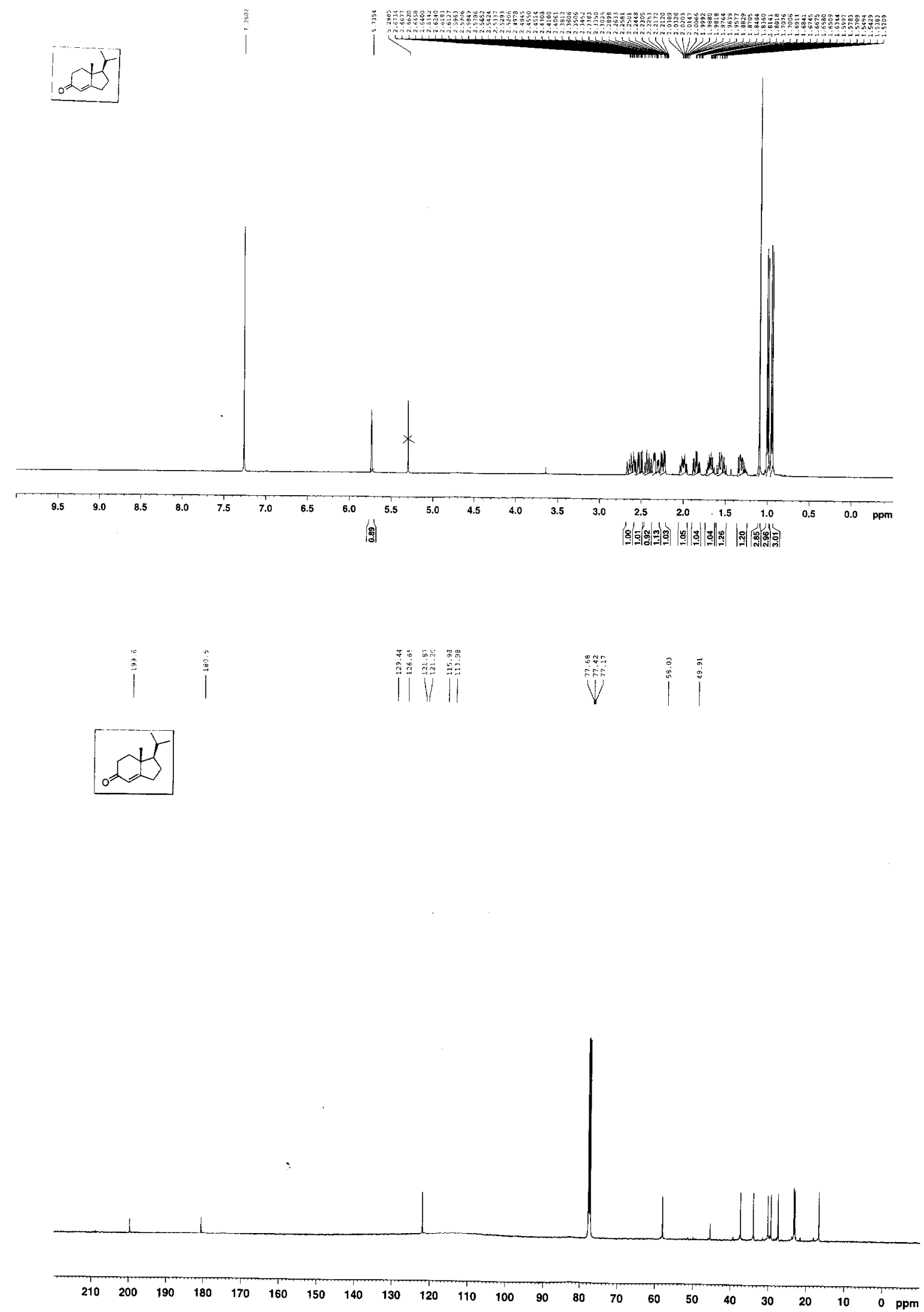


\section{Compound 98}

$$
\text { cots }
$$
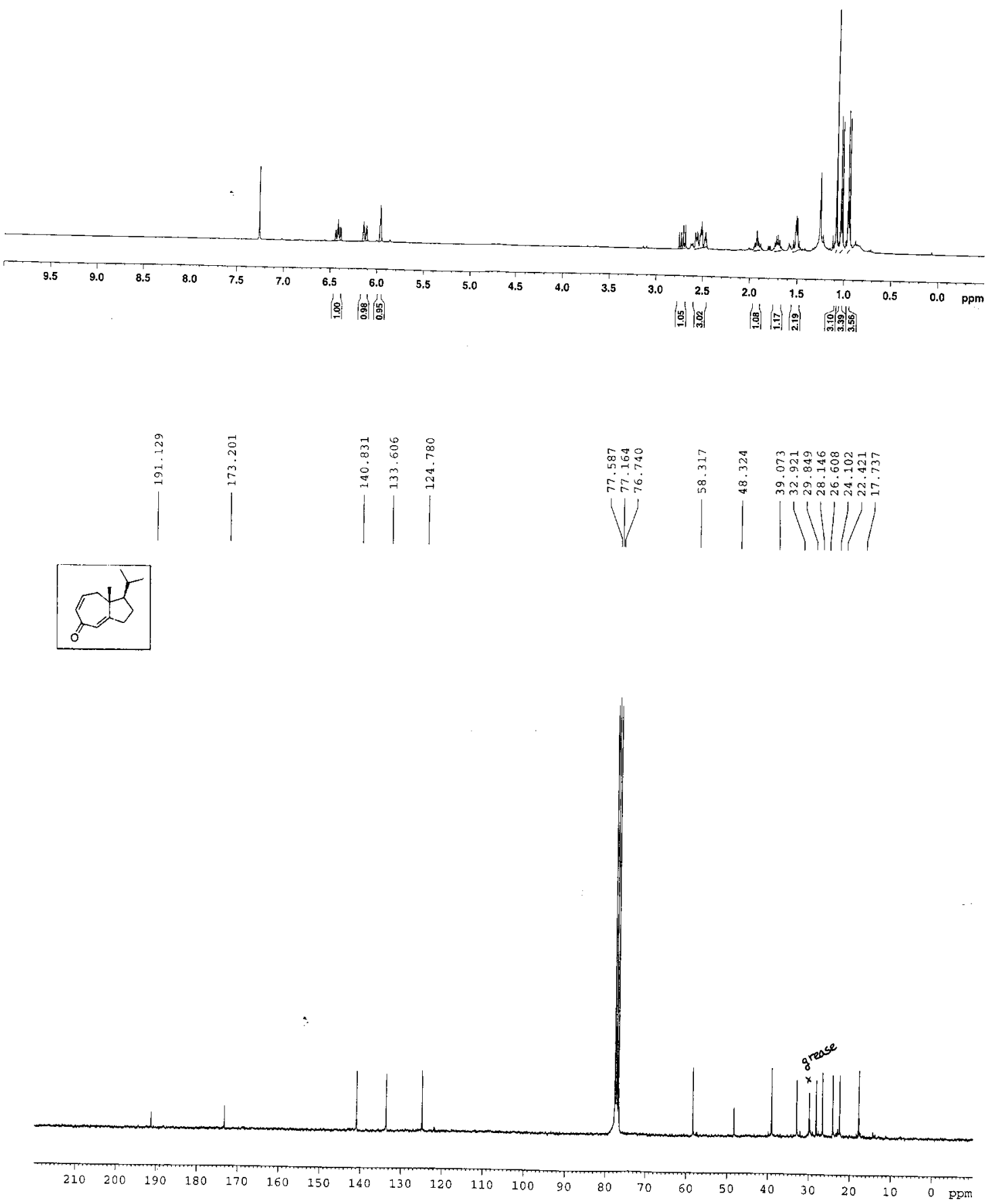


\section{X-Ray Structure of 73}

The structure of $\mathbf{7 3}$ has been determined by a single-crystal X-ray analysis. In the crystal, the methyl group $\mathrm{C}-20$ is disordered. Perspective drawings of Rotamer $A$ (approximately 75\% occupancy) and Rotamer B (approximately 25\% occupancy) of 73 are shown in the Figures 1 and 2. The hydroxyl group of a molecule of $\mathbf{7 3}$ forms an intermolecular hydrogen bonds with the carbonyl oxygen.

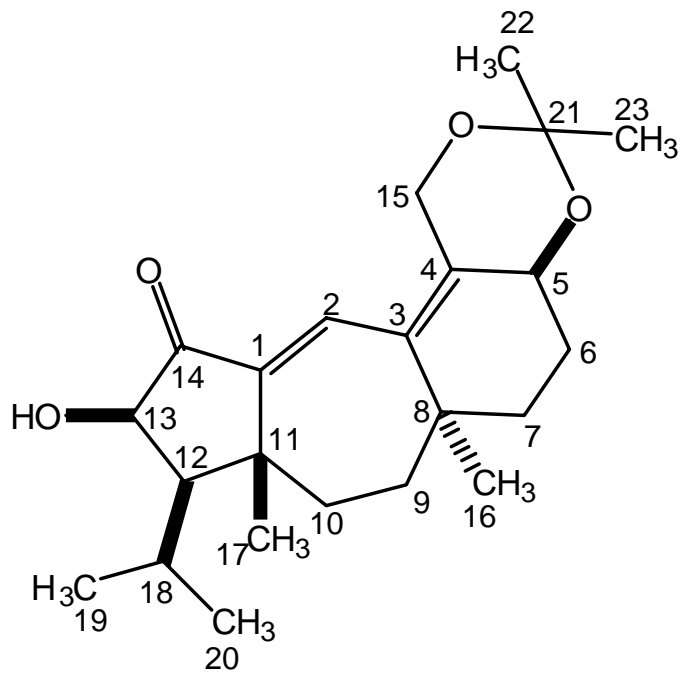

73

(racemic)

The intensity data were measured on an Enraf-Nonius CAD4 diffractometer (graphite-monochromated $\mathrm{Cu} K \alpha$ radiation, $\omega-2 \theta$ scans). The size of the crystal used for data collection was approximately $0.44 \times 0.56 \times 0.88 \mathrm{~mm}$. The data were not corrected for absorption. Of the 3150 independent reflections for $\theta<60^{\circ}$, 2053 were considered observed [ $I>3.0 \sigma(I)]$.

The structure was solved by a multiple-solution procedure ${ }^{1}$ and was refined by full-matrix least squares. In the final refinement, the nonhydrogen atoms were refined anisotropically. The hydrogen atoms were included in the structure-factor calculations, but their parameters were not refined. The final discrepancy indices are $R=0.0610$ and $R_{W}=0.0669$ for the 2053 observed reflections. The final difference map has no peaks greater than \pm 0.22 e $\AA^{-3}$. The X-ray data are summarized in Tables I to VI.

1. P. Main, S. Fiske, S. Hull, L. Lessinger, G. Germain, J. P. Declercq, M.Woolfson, (1982). MULTAN 11/82. University of York, England and University of Louvain, Belgium. 


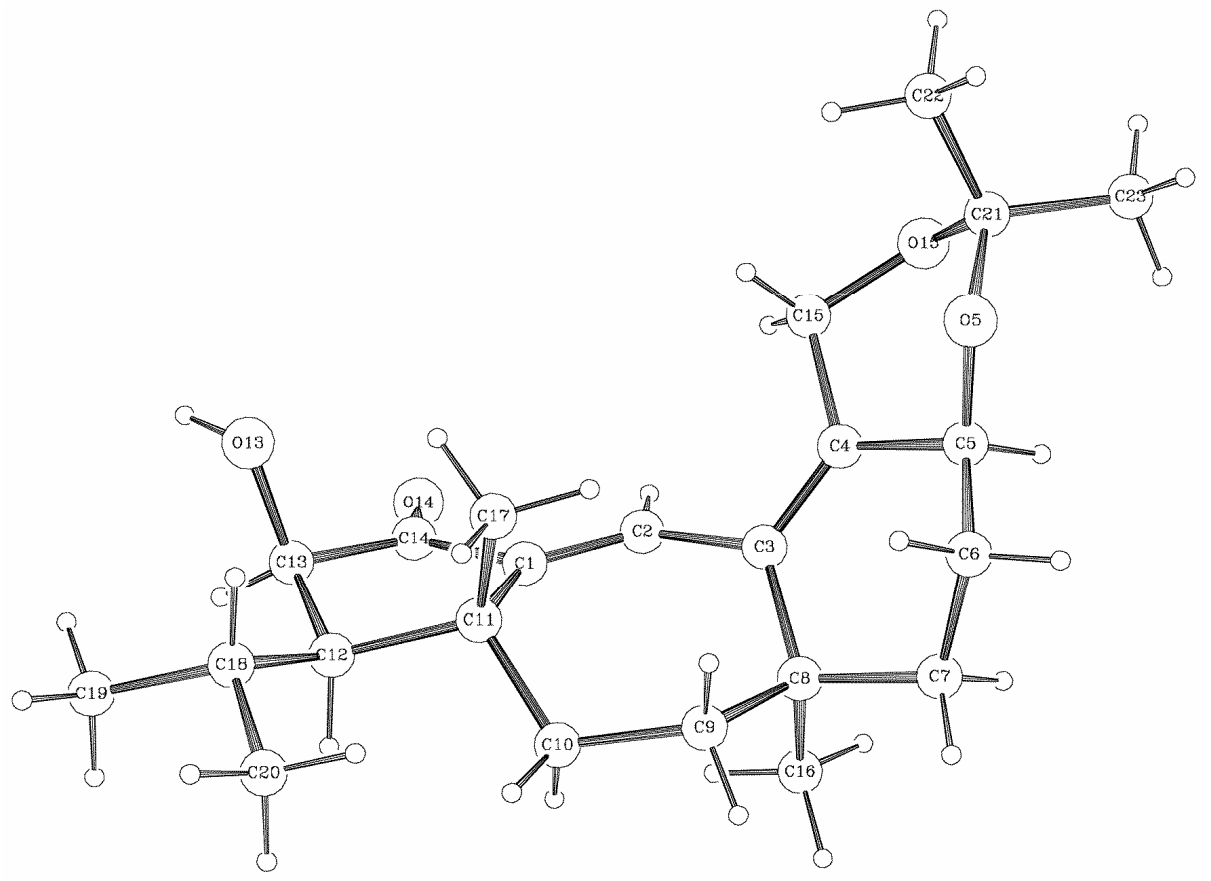

Figure 1. X-ray structure of Rotamer A (approximately 75\% occupancy) of 73 at $295 \mathrm{~K}$

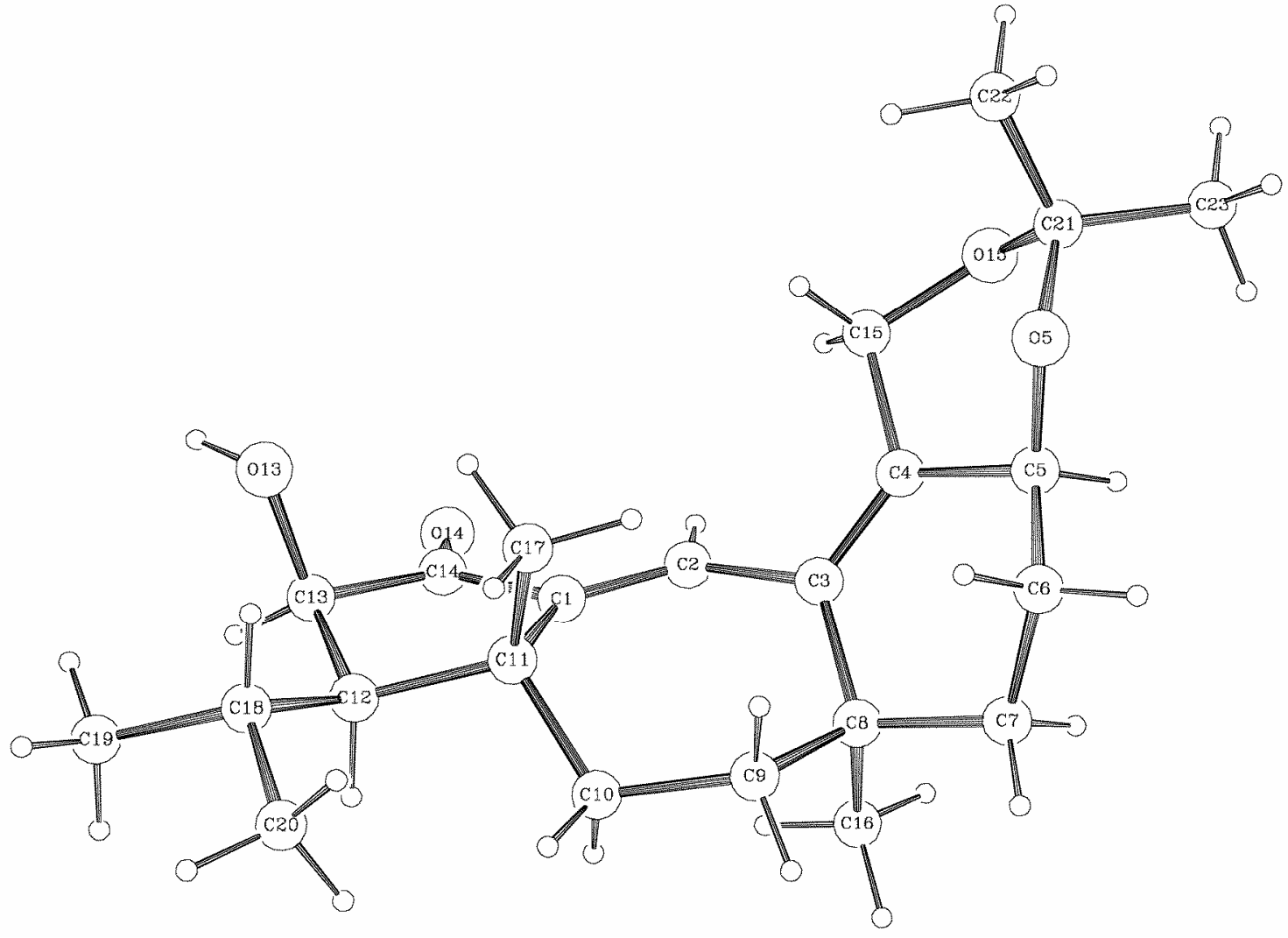

Figure 2. X-ray structure of Rotamer B (approximately 25\% occupancy) of $\mathbf{7 3}$ at $295 \mathrm{~K}$ 